\title{
Movimento bidirecional no transporte intracelular mediado por motores moleculares
}

Daniel Gomes Lichtenthäler

São Paulo

2007 

Universidade de São Paulo

Instituto de Física

\title{
Movimento bidirecional no transporte intracelular mediado por motores moleculares
}

\author{
Daniel Gomes Lichtenthäler
}

Orientadora: Profa. Dra. Carla Goldman

Dissertação de mestrado apresentada ao Instituto de Física da USP para obtenção do título de Mestre em Ciências

Comissão Examinadora:

Profa. Dra. Carla Goldman (IF-USP)

Prof. Dr. Nestor F. Caticha Alfonso (IF-USP)

Prof. Dr. Clodoaldo Grotta Ragazzo (IME-USP) 



\section{Resumo}

Neste trabalho apresentamos um modelo teórico que busca descrever aspectos do movimento bidirecional apresentado por objetos intracelulares (vesículas, organelas, vírus etc, aos quais iremos nos referir simplesmente como "vesículas"), observado sobretudo em experimentos in vivo. Este movimento não-difusivo é caracterizado por inversões rápidas em sua direção e é capaz de gerar gradientes de concentração do objeto transportado.

Os fenômenos de transporte intracelular são sabidamente mediados por proteínas motoras (como as kinesinas e dineínas) cujo movimento unidirecional sobre filamentos proteicos é bem caracterizado (kinesinas se movem em direção à extremidade-mais enquanto as dineínas se movem em direção à extremidade-menos dos microtúbulos) e é normalmente entendido através de modelos estocásticos que descrevem o comportamento de uma partícula browniana na presença de um potencial assimétrico que varia no tempo (ver Astumian [26], Adjari e Prost [22], Magnasco [23]). Mais recentemente, surgiram na literatura trabalhos que tentam descrever o movimento de partículas motoras interagentes, uma vez que se percebeu que efeitos coletivos que surgem nestas situações podem ser relevantes para os fenômenos de transporte sobre microtúbulos. Uma abordagem para a descrição do comportamento destes sitemas de partículas motoras interagentes é aquela baseada nos modelos para os "sistemas difusivos dirigidos". Em particular, a versão contínua dos modelos do tipo "totally asymmetric exclusion processes" (TASEP) e "asymmetric exclusion processes" (ASEP) têm sido utilizada para o estudo do comportamento da densidade de motores sobre os microtúbulos, através da análise de soluções estacionárias da equação de Burgers correspondente (Parmeggiani et al. [33]). Até agora, entretanto, não existem na literatura tentativas de abordar, com estes modelos, o transporte bidirecional de vesículas mediado por estes motores interagentes.

A idéia que apresentamos aqui é associar este estranho tipo de movimento ao movimento de ondas de choque presentes nas soluções transientes da equação de Burgers para algumas condições iniciais. Deste modo, as vesículas acompanhando ("surfando") os choques fariam o papel de suas correspondentes microscópicas "partículas de segunda classe", introduzidas há um bom tempo na literatura [36], [37], [38] para o estudo da dinâmica microscópica dos choques que estão presentes também na versão discreta dos modelos TASEP e ASEP. Neste sentido, é natural que as condições iniciais consideradas, que seriam perturbações no estado estacionário das partículas, possam ser causadas, no sistema real, pela própria interação com a vesícula. É o caso, portanto, de se propor que a geometria deste objeto tenha um papel importante na determinação da direção final de seu próprio movimento no meio intracelular. Esta parece ser, por exemplo, uma alternativa interessante para explicar aspectos do movimento de vírus no interior das células. 



\begin{abstract}
In this work we present a theoretical model to describe aspects of the bidirectional movement performed by intracellular structures (vesicles, organelles, viruses etc, to which we refer here simply as "vesicles"), observed essentially at in vivo experiments. This nondiffusive movement is characterized by rapid inversions in direction and is capable of creating concentration gradients of the transported cargo.

The phenomenon of intracellular transport is known to be mediated by motor proteins (such as kinesins and dyneins) whose own unidirectional motion along protein filaments is well characterized (kinesins moves to the plus-end direction while dyneins moves to the minus-end direction of the microtubules) and is usually modeled by a stochastic dynamics describing the behavior of a Brownian particle in the presence of a time dependent asymmetrical potential field (see Astumian [26], Adjari and Prost [22], Magnasco [23]). More recently, it appeared in the literature works attempting to describe the movement of interacting motor proteins, since it was realized that collective effects emerging from this situation may be relevant to the transport phenomena along microtubules. An approach to describe the behavior of such interacting motor particles is based on existing models for "driven diffusive systems". In particular, the continuum versions of the "totally asymmetric exclusion processes" (TASEP) or the "asymmetric exclusion processes" (ASEP) have been used to study the behavior of motors density along microtubules by analyzing the steady state solutions to the corresponding Burgers equation (Parmeggiani et al. [33]). Up to now, however, there are no attempts in the literature to approach in this context the questions related to the bidirecionality of vesicles transported by these interacting motors.

The idea we present here is to associate this odd movement to the movement of shock waves presented by the transient solutions of Burgers equation for certain initial conditions. Accordingly, the vesicles accompanying (surfing) the shocks fronts would play the role of their microscopic analogous "particles of second class" introduced long ago in the literature [36], [37], [38] to study the kinetics of the shocks that are also present in the discrete versions of the TASEP and ASEP. In this regard, it is natural to think that the considered initial conditions, namely perturbations to the motor density with respect to a steady state, can be created in the real systems simply by the interaction with the vesicle. It might then be the case also to propose that the geometry of the vesicle plays an important role to direct its own movement within intracellular environment. This seems to be, for example, an attractive alternative for explaining aspects of virus movement inside the cell.
\end{abstract}



Este trabalho é dedicado à memória de meu avô,

Rubens Lichtenthäler. 



\section{Agradecimentos}

Agradeço o apoio e a confiança de toda minha família, em especial à minha mãe, Marcia Irulegui Gomes e ao meu pai, Rubens Lichtenthäler Filho, às minhas avós Ione e Célia, à minha tia, Isolda e à minha irmã Alice.

Ao meu avô, Luiz Carlos Gomes, agradeço não apenas o apoio, mas também o auxílio com a Física e a imposição do uso de $\mathrm{AT}_{\mathrm{E}} \mathrm{X}$ (sem dúvida a melhor opção!), além de algumas revisões críticas.

Agradeço imensamente à Caroline Gabriel Pedro pelo enorme auxílio com as figuras, pela paciência em revisar atentamente todo o texto e por tornar meu trabalho bem menos penoso.

Aos meus amigos e amigas, que sempre acreditaram mais do que eu na minha capacidade e me ajudaram no que puderam, mais do que imaginam.

Um agradecimento especial à Carla, que foi extremamente compreensiva quando eu precisei, mas soube cobrar com veemência quando necessário, sem jamais deixar de ser delicada. Ao $\mathrm{CNPq}$, pelo apoio financeiro. 



\section{Conteúdo}

Introdução $\quad$ xvii

1 Modelos Mínimos para Motores Moleculares 1

1.1 Modelo para um motor molecular proposto por Adjari e Prost . . . . . . . 5

1.2 Modelo para um motor molecular proposto por Astumian . . . . . . . . . . 11

1.3 Simulação do modelo de Astumian . . . . . . . . . . . . . . . . . . 16

2 Experimentos que apresentam bidirecionalidade $\quad 21$

2.1 Transporte intracelular sobre microtúbulos: aspectos bioquímicos e parâmetros biofísicos . . . . . . . . . . . . . 24

2.2 Transporte de Vesículas Lipídicas: um modelo experimental bem caracterizado . . . . . . . . . . . . . . . . . . . . . . . . 27

2.3 Modelos teóricos encontrados na literatura para explicar o transporte bidirecional . . . . . . . . . . . . . . . . . . . . . 32

3 Sistemas difusivos dirigidos: modelos do tipo ASEP e TASEP 36

3.1 Conexão entre modelos mínimos e modelos do tipo ASEP e TASEP . . . . 38

3.2 A aproximação de campo médio e o limite contínuo para o modelo ASEP . 41

3.3 Diagrama de fases para o ASEP . . . . . . . . . . . . . . . . 43

4 O movimento de vesículas: deslizando na crista da onda de choque 48

4.1 Explicação alternativa para o movimento bidirecional mediado por motores moleculares . . . . . . . . . . . . . . . . . . . . . . . 48 
4.2 Solução da equação de Burgers para uma condição inicial especial .... 50

5 Discussão sobre o modelo proposto

5.1 Um possível mecanismo molecular que explique nosso modelo mesoscópio . 62

5.2 Comparação das previsões teóricas do modelo proposto com dados experimentais . . . . . . . . . . . . . . . . . 63

5.3 Vantagens e desvatagens apresentadas pelo modelo proposto . . . . . . . 66

Conclusão

Apêndice A

A-1 Equações Diferenciais Lineares . . . . . . . . . . . . . . . . . . . . 72

A-2 Equações Quasi-lineares . . . . . . . . . . . . . . . 75

A-2.1 Ondas de rarefação . . . . . . . . . . . . . . . . . 76

A-2.2 Ondas de choque . . . . . . . . . . . . . . . . 77

Apêndice B

Bibliografia 


\section{Lista de Figuras}

1.1 Modelo de potencial periódico assimétrico "dente-de-serra". O Potencial $U_{0}$ é parametrizado pelos valores de $a, b$ e $U_{\max }$, sendo $a$ a distância entre um mínimo local e o máximo a sua esquerda e $b$ a distância entre um mínimo e o máximo a sua direita, $U_{\max }$ é o valor máximo que o potencial atinge. .......................... 6

1.2 Potencial periódico e assimétrico que oscila com freqüência $\gamma$ entre dois estados $U^{+}(x)$ e $U^{-}(x)$. F é uma força externa constante, de direção contrária ao movimento gerado pelo potencial oscilatório, que pode eventualmente estar presente. Fonte: Astumian (1996) [26] . . . . . . . . . . . . . . . 12

1.3 Fluxo $J(\gamma)$ de partículas como função do logarítmo da freqüência calculado para $F=0$. Fonte: Astumian (1996) [26] . . . . . . . . . . . . . . . 15

1.4 Velocidade média das partículas (proporcional ao fluxo pois assumiu-se uma densidade constante de partículas) em função da freqüência $\gamma$ (em escala logarítimica, de modo a permitir uma melhor comparação com a Figura 1.3) de oscilação do potencial, para baixas freqüências (dentro do limite adiabático). A força externa utilizada é nula $(F=0)$ e $k_{B} T=1$. As unidades utilizadas são arbitrárias e os valores mostrados são médias de 400 simulações. . . . . . . . . . . . . . . . . . . . . . 17

1.5 Velocidade média das partículas em função da freqüência $\gamma$ de oscilação do potencial, para uma ampla faixa de freqüência. A força externa utilizada é nula $(F=0)$ e $k_{B} T=1$. As unidades utilizadas são arbitrárias e os valores mostrados são médias de 400 simulações. . . . . . . . . . . . . . . . 18

1.6 Velocidade média das partículas em função da força externa $F$ contrária ao movimento (aqui utilizamos $k_{B} T=1$ e $\gamma=1$ ). As unidades utilizadas são arbitrárias e os valores mostrados são médias de 400 simulações. . . . . . 19 
2.1 Diagrama de uma célula, mostrando a organização radial dos microtúbulos e alguns objetos intracelulares que se movem bidirecionalmente, fazendo uso de proteínas motoras multiméricas. Fonte: Gross (2004) [27]. . . . . . .

3.1 Modelo de transporte de partículas interagentes em redes unidimensionais do tipo ASEP. As partículas têm probabilidades diferentes, p e q, de saltar para os sítios vizinhos desocupados à direita e à esquerda respectivamente, e, se estes estiverem ocupados, a probabilidade de transição é nula. No modelo do tipo TASEP, a probabilidade de transição para um dos lados é nula (por exemplo, $q=0) \ldots \ldots \ldots \ldots$. . . . . . . . . . . . . . . . .

3.2 Condição inicial do tipo "degrau". Ilustramos a condição inicial $\rho(x, 0)=\alpha$ para $x<0$ e $\rho(x, 0)=1-\beta$ para $x>0$ para o caso $\alpha<1 / 2$ e $\beta<1 / 2$. .

3.3 Diagrama de fases para o estado estacionário do modelo TASEP. Conforme explicado no texto, temos três fases: corrente máxima (para $\alpha<1 / 2 \mathrm{e}$ $\beta<1 / 2$ ), baixa densidade (para $\beta>1 / 2$ e $\alpha<\beta$ ) e alta densidade $(\alpha>1 / 2$ e $\beta<\alpha)$

4.1 Perfil de densidade definido pela condição inicial (4.3). Em nosso modelo supomos que este perfil represente a perturbação que a vesícula causa na densidade estacionária de motores, que consideramos igual a 1/2 (de modo que o fluxo de motores no estado estacionário é máximo) . . . . . . . . . . . 52

4.2 Mapa de características obtido, conforme explicado no texto, pelo método das características (descrito no Apêndice A) para a equação (3.18), dada condição inicial (4.3). Indicamos as regiões de rarefação 1 e 2 respectivamente por R1 e R2, e as famílias de características $x_{1}, x_{2}, x_{3}, x_{4}$ e $x_{5}$ da equação (4.5) pelas letras C1, C2, C3, C4 e C5, respectivamente. A linha preta mais espessa indica os choques entre as características, as linhas pontilhadas indicam os instantes iniciais dos choques (ver Tabela 4.1): $t_{3}^{0}=\frac{a}{2 \varepsilon}$, $t_{4}^{0}=\frac{3 a}{4 \varepsilon}, t_{5}^{0}=\frac{4 a}{3 \varepsilon}, t_{6}^{0}=\frac{4 a}{\varepsilon} \ldots \ldots \ldots \ldots \ldots \ldots$

4.3 Perfil de densidade em diversos instantes do estado transiente de um TASEP, de acordo com solução (4.52). A vesícula é representada esquematicamente (disco cinza), acompanhando o movimento dos choques partindo do choque 2 , a seta indica o sentido da velocidade naquele instante. (a) instante inicial $(t=0)$, os choques 1 e 2 se formam com a perturbação inicial, (b) perfil entre o instante inicial e $t_{3}^{0}=\frac{a}{2 \varepsilon}$, (c) instante $t_{3}^{0}=\frac{a}{2 \varepsilon}$ em que ocorre o terceiro choque, (d) instante $t_{4}^{0}=\frac{3 a}{4 \varepsilon}$ em que ocorre o quarto choque, (e) instante $t_{5}^{0}=\frac{4 a}{3 \varepsilon}$, quando se inicia o quinto choque, (f) instante $t_{6}^{0}=\frac{4 a}{\varepsilon}$ quando o último choque se inicia. . . . . . . . . . . . . . . . . . . . 
A-1 Família de características lineares definidas pela equação (A-6). Cada valor de $x_{0}$ define uma curva característica $x(t)$ específica. . . . . . . . . . 73

A-2 Condição inicial definida na equação $($ A-9) . . . . . . . . . . . . . . . . 74

A-3 Solução (A-15) da equação (A-1) para a condição inicial (A-9) . . . . . . . 75

A-4 Representação gráfica de duas famílias de características com velocidades tais que se forma uma região de rarefação entre elas. . . . . . . . . . . . . 77

A-5 Ondas de choque: Características que partem de diferentes valores de $x_{0}$ em $t=0$, nos quais a condição inicial é diferente, e se interceptam em um tempo posterior, levam a uma solução descontínua. Esta descontinuidade é conhecida como choque ou onda de choque. . . . . . . . . . . . . . . . . . 77 


\section{Lista de Tabelas}

1.1 Estados catalíticos de uma ATPase. . . . . . . . . . . . . . . . . . 2

4.1 Propriedades dos choques para a condição inicial dada pela equação (4.3) 58 


\section{Introdução}

Os fenômenos relacionados ao transporte em escala molecular vêm instigando, já há algum tempo, pesquisadores de diversas áreas, como físicos, químicos e biólogos. Tal interesse torna-se cada vez maior à medida que se desvendam novas possibilidades de manipulação de objetos em escala molecular. A nanotecnologia, área do conhecimento humano que busca o desenvolvivento de tecnologia nesta escala, vem sendo apontada como uma área extremamente promissora da ciência, dado o seu enorme potencial de aplicações. O interesse da nanotecnologia nos mecanismos de transporte molecular é enorme, não apenas pelas inúmeras possibilidades que o controle do movimento ordenado de moléculas oferece, como também, pela possibilidade de, imitando os princípios utilizados pela natureza, desenvolver novos motores em escala nanométrica, capazes de realizar trabalho eficientemente num ambiente extremamente ruidoso (devido à agitação térmica) [1]. Isso já nos motiva a compreender como tais fenômenos de transporte são explicados pela física.

Quando vistos por seu aspecto biológico, estes fenômenos de transporte molecular intracelular se mostram ainda mais interessantes. A análise genética tem mostrado que o surgimento de complexos moleculares capazes de realizar transporte direcionado por distâncias relativamente longas se confunde com um grande salto na evolução da vida na Terra, o surgimento das células eucariotas. Estas células, quando comparadas às suas antecessoras evolutivas, as células procariotas (bactérias), apresentam um grau muito maior de complexidade, com diversos compartimentos (organelas) que realizam funções bem definidas, organizados de modo assimétrico, num espaço intracelular muito maior. Em organismos multi-celulares, este grau de organização toma proporções ainda maiores com o surgimento de células que apresentam longos prolongamentos celulares, como os neurônios que podem apresentar axônios com comprimentos da ordem de metros. De fato, não é difícil imaginar que tais células, para realizarem suas funções básicas, devam possuir um alto grau de organização interna, para o qual torna-se necessário um mecanismo eficiente de transporte de moléculas, vesículas e organelas. Esta complexidade organizacional parece só ter sido possível a partir do surgimento dos chamados motores moleculares, dado que eles estão presentes em todas as células dos organismos eucariotos enquanto que, nos procariotos, eles até agora não foram encontrados [2].

Nas ciências médicas, o interesse pelo transporte intracelular não é menor, dado que a 
compreensão deste fenômeno tem se mostrado essencial para que se consiga um melhor entendimento da fisiopatologia de diversas doenças. Tem-se demonstrado, em modelos experimentais, que diversas patologias podem surgir de defeitos na maquinária molecular que realiza este transporte, como, por exemplo, a observação da disfunção do neurônio motor em Drosophilas mutadas [3] e, em camundongos, defeitos na formação da assimetria esquerda-direita (situs inversus) [4] e doença do rim policístico [5], [6].

Recentemente se tem encontrado, também em humanos, a relação de doenças com o mau funcionamento de motores moleculares. Mutações em genes de alguns destes motores já foram relacionadas à doença de Charcot-Marie-Tooth do tipo 2A [7] e à paraplegia espástica hereditária [8]. Encontram-se também fortes evidências da relação de problemas nos mecanismos de transporte intracelular com doenças como a síndrome de Griscelli [9], a doença de Alzheimer [10], [11] e a doença de Huntington [12]. Doenças virais também parecem estar fortemente relacionadas com os mecanismos de transporte intracelular. Alguns vírus (como o adenovírus, o HIV, e vírus neurotróficos como o Herpes simplex virus - HSV) fazem uso da maquinária de transporte presente na célula para se locomover rapidamente no citoplasma [13], [14], [15].

O transporte intracelular por longas distâncias, em células eucariotas, parece ocorrer de três maneiras possíveis: (i) por mecanismos de polimerização e despolimerização de filamentos de actina; (ii) por fluxo de material citoplasmático; (iii) e através do movimento vetorial (direcionado) ao longo das fibras do cito-esqueleto [16]. No presente trabalho trataremos apenas deste terceiro modo de transporte, que é o melhor compreendido além de ser o mais freqüentemente utilizado na formação de micro-ambientes no interior das células eucariotas [2]. Este mecanismo é aquele realizado pelos motores moleculares, capazes de se locomover direcionadamente sobre este sistema de filamentos proteicos chamado cito-esqueleto.

De modo geral, motores moleculares são definidos como complexos moleculares capazes de realizar trabalho mecânico. Tais motores realizam trabalho mecânico ao transportar, de modo vetorial, objetos massivos como macromoléculas, vesículas e organelas em um meio viscoso. Todos os motores moleculares biológicos possuem unidades enzimáticas em uma das proteínas do complexo, conhecida como proteína motora, que passa por drásticas mudanças conformacionais ao logo do ciclo catalítico. A rigor, pode-se considerar o motor biológico como sendo não apenas a proteína motora, mas todo o complexo, incluindo a estrutura sobre a qual ela se locomove - em geral um filamento proteico. Neste trabalho adotaremos, entretanto, a nomenclatura mais usual que confunde os termos proteína motora e motor molecular. Alguns autores ampliam ainda mais este termo, utilizando-o também para bombas iônicas que, apesar de não realizarem trabalho mecânico, realizam trabalho termodinâmico ao transportar íons contra o gradiente de potencial eletroquímico.

A atividade enzimática apresentada pelo motor (e também pelas bombas iônicas) é quase 
invariavelmente a hidrólise da molécula de adenosina tri-fosfato ou ATP (atividade ATPásica). No meio intracelular, esta reação de hidrólise é mantida a todo instante fora de equilíbrio através de processos como fermentação e respiração celular [17]. É esta reação que fornece a energia necessária para que o transporte vetorial ocorra. Por consumir ATP, este transporte vetorial é conhecido em biociências com transporte ativo, em contraste com os transportes passivos, que ocorrem apenas por difusão, sem gasto de energia.

No meio intracelular, diversos exemplos de complexos moleculares que apresentam movimento vetorial estão presentes. Em alguns casos, o deslocamento de uma partícula globular sobre um filamento se dá não somente com o objetivo de transporte de objetos massivos, mas também porque tal movimento é imprescindível biologicamente para que ocorra a interação necessária entre estas moléculas. Este é o caso, por exemplo, dos ribossomos que se deslocam sobre as moléculas de RNA mensageiro e de diversas proteínas que se deslocam sobre o DNA, como as helicases e as DNA e RNA polimerases. No caso das proteínas motoras, o transporte de objetos como vesículas lipídicas, organelas celulares (como mitocôndrias), e macromoléculas (como RNA), é o principal resultado da atividade realizada por estas enzimas. Este fato sugere que a pressão seletiva durante a evolução tenha agido sobre tais moléculas no sentido de otimizar suas atividades motoras, tornando o mecanismo de transporte utilizado o mais vantajoso possível para a célula. Nosso principal objeto de estudo será, então, o transporte realizado por estas proteínas motoras ao se deslocarem sobre filamentos proteicos, apesar de alguns dos modelos aqui apresentados serem suficientemente gerais para tratar o movimento realizado pelos outros complexos citados acima.

As proteínas motoras podem ser agrupadas em três superfamílias de origem evolutiva comum: (i) a superfamília das miosinas, que se deslocam sobre filamentos de actina; (ii) a superfamília das kinesinas, que se deslocam sobre os microtúbulos (filamentos de tubulina), na maioria dos casos, em direção à extremidade-mais; (iii) a superfamília da dineínas que se deslocam sobre os microtúbulos em direção à extremidade-menos [2]. Os filamentos sobre os quais estes motores se deslocam são polímeros proteicos periódicos, porém assimétricos, apresentando extremidades distintas tanto morfológica como quimicamente [16]. Torna-se cada vez mais claro que todas essas proteínas motoras apresentam atividade ATP-ásica em estrita associação com o movimento vetorial realizado sobre o filamento, normalmente uma molécula de ATP hidrolisada para cada passo dado pelo motor (transição do motor de um monômero para o monômero seguinte no filamento) [18], [19].

Os primeiros modelos teóricos que surgiram na literatura para descrever a ação de complexos moleculares biológicos capazes de realizar alguma forma de trabalho, seja ele mecânico ou termodinâmico (como na construção e manutenção de gradientes iônicos), datam da década de 70, com os trabalhos de Hill [20] e Montroll [21]. Tais trabalhos procuravam descrever a ação conjunta das proteínas actina e miosina no processo de con- 
tração muscular, assim como o transporte ativo de íons através de membranas celulares, realizado por proteínas chamadas de "bombas iônicas". Nestes trabalhos, a descrição dos processos acima é fundamentada na teoria cinética das reações químicas, formulada para um modelo de vários estados. No caso da contração muscular, tais estados são associados às diversas configurações por que passam as moléculas de miosina, conforme estas se deslocam sobre o filamento de actina durante o ciclo enzimático. Já na descrição do transporte ativo de íons, os diversos estados estariam associados às diferentes configurações do complexo enzima-substrato que promove o transporte iônico através das membranas.

Neste contexto, a evolução temporal da densidade de partículas (moléculas) em cada um destes estados é descrita em termos de equações diferenciais ordinárias, de primeira ordem, acopladas, sendo as taxas com que cada estado pode ser atingido a partir dos outros consideradas parâmetros do modelo. Em geral, estes processos enzimáticos são processos cíclicos em que cada ciclo inclui a hidrólise de uma mólecula de ATP, acompanhada seja pelo deslocamento da proteína motora de um monômero para outro no filamento, seja pelo transporte de íons através da membrana, no caso das bombas iônicas. Como em geral as taxas de transição entre os estados são obtidas empiricamente, podemos dizer que este tipo de descrição corresponde a uma visão fenomenológica, do problema dinâmico.

No início da década de 90, surgiu na literatura outro tipo de abordagem para o transporte realizado por proteínas motoras. Esta é uma abordagem calcada numa visão microscópica dos processos descritos acima e busca descrevê-los como transporte induzido por flutuações fora de equilíbrio (ver [22], [23], [24]). Tal abordagem visa sobretudo dar uma explicação para o fenômeno de transporte molecular vetorial partindo de princípios básicos da física, em particular, da física de processos estocásticos. Os modelos descrevem como a partícula motora se move vetorialmente num ambiente onde o ruído térmico é importante - cunhou-se então o termo "motor molecular browniano". O ponto de partida deste tipo de descrição foi inspirado no modelo da "catraca" (ratchet and powl) proposto por R. P. Feynman para ilustrar o significado da segunda lei da termodinâmica [25]. Os ingredientes essenciais da proposta contida nestes modelos para motores moleculares são flutuações estocásticas de grandezas relevantes, na presença de assimetrias espaciais e/ou temporais manifestadas no nível molecular.

Para ilustrar este tipo de abordagem ao fenômeno de transporte molecular, analisamos, no primeiro capítulo, um destes modelos proposto por Astumian [26], para o qual é descrita uma solução analítica, supondo um regime adiabático que nos permite fazer uso de uma abordagem cinética para o modelo. Em seguida, apresentamos resultados que obtivemos através da simulação computacional da equação de Langevin associada a este modelo, que coincide, no limite adiabático, com a solução analítica obtida. Com a análise deste modelo, esperamos esclarecer de que forma a física consegue explicar como o fenômeno de transporte molecular é possível num ambiente microscópico onde o ruído térmico, que à primeira vista poderia-se supor altamente desfavorável ao transporte 
vetorial, se mostra essencial para a realização deste movimento. Consideramos assim, que o movimento vetorial de uma partícula motora está razoavelmente bem entendido do ponto de vista dos conceitos e grandezas físicas envolvidos. Pelo fato deste tipo de modelo descrever o movimento unidirecional que se observa para os motores moleculares, pode-se considerar que o movimento unidirecional de vesículas, organelas e macromoléculas seja explicado simplesmente pelo fato destas organelas estarem sendo carregadas por um ou alguns destes motores. Entretanto, em experimentos realizados in vivo tem-se observado cada vez mais que o transporte de tais objetos intracelulares, pode apresentar fenômenos mais complexos do que o simples movimento unidirecional [16], [27]. Tais fenômenos não podem ser descritos pela simples associação direta do movimento destes objetos ao movimento direcionado (ainda que apenas estatisticamente) de partículas motoras num filamento.

Um destes fenômenos, que nos despertou interesse especial, é a bidirecionalidade observada no movimento de vesículas lipídicas, organelas, macromoléculas e mesmo alguns vírus transportados no meio intracelular por motores moleculares , [28], [29], [30], [31]. O movimento bidirecional é caracterizado por mudanças abruptas na direção do movimento de tais objetos, que, muitas vezes, estão sendo transportados ativamente sobre o filamento numa direção e passam, de modo quase instantâneo (em no máximo alguns milissegundos), a ser transportados na direção oposta [16], [27]. Claramente não se trata de um movimento difusivo em uma dimensão, mas sim da composição de movimentos vetoriais (que duram tempos da ordem de segundos em cada direção) cujo sentido é alternado sucessivas vezes. Nosso trabalho está norteado por uma proposta alternativa para descrever este movimento bidirecional observado no meio intracelular. Assim, realizamos no Capítulo 2, uma revisão dos principais resultados experimentais que reportam tal fenômeno, sobretudo aqueles com os quais dialogaremos mais adiante.

Para tentar explicar a observação destes fenômenos mais complexos que o simples transporte direcionado de partículas, nos vimos diante da necessidade de uma nova abordagem para o estudo do transporte intracelular de objetos massivos. Buscavamos agora, não mais entender como os processos físcos envolvidos no sistema são capazes de gerar o movimento direcionado de uma partícula motora, mas sim como o transporte de vesículas lipídicas realizado por tais partículas pode apresentar fenômenos como a bidirecionalidade. Procuramos então, modelos que apresentem maior grau de complexidade, sobretudo modelos que tratassem as possíveis interações entre vários motores, uma vez que, como era de se imaginar, tem-se observado que vários deles podem se deslocar simultaneamente num mesmo filamento, produzindo novos fenômenos como a coexistência de regiões de alta e baixa densidade de motores [32].

Buscamos modelos que já assumissem o movimento direcionado de cada partícula motora que se move sobre o filamento, o que nos remeteu aos chamados "sistemas difusivos dirigidos" (driven difusive sistems). Dentre estes, os chamados modelos do tipo ASEP 
(asymetric simple exclusion model) e TASEP (totaly asymetric simple exclusion model), se mostram bastante razoáveis para tentar descrever efeitos no transporte resultantes da interação por volume excluído de várias partículas motoras que se movem sobre um mesmo filamento [33]. Estes modelos são descritos no terceiro capítulo desta dissertação. Faremos em seguida uma conexão entre tais modelos e os modelos mínimos vistos no Capítulo 1 e, então, tratamos os modelos do tipo ASEP com aproximações do tipo campo-médio, tomando em seguida o limite do contínuo, de modo a reduzir nosso problema à solução de uma equação diferencial parcial quasi-linear, de primeira ordem, para a densidade média de partículas ao longo do filamento. Obtemos também, a partir da escolha de condições iniciais apropriadas, o diagrama de fases conhecido para condições abertas de contorno [34], [35]. Neste estudo já fica evidente que tais modelos podem apresentar choques, ou seja, transições abruptas entre uma região do filamento com baixa densidade de partículas e uma região com alta densidade, dependendo das condições de contorno. O fato de conseguirmos obter tal diagrama, que Derrida et al. [35] obtiveram através de um método analítico sem aproximações, indica que o tratamento no limite do contínuo é razoável.

Visando dar uma explicação alternativa para a bidirecionalidade observada no movimento de vesículas transportadas por motores moleculares, propomos, no quarto capítulo, uma nova interpretação para um modelo criado por Andjel et al. [36] que foi posteriormente analisado e resolvido por Ferrari et al. [37] e Derrida et al. [38]. Este modelo tinha originalmente o objetivo de estudar a dinâmica microscópica dos choques observados no TASEP simples por meio da introdução de um novo tipo de partículas (partícula de segunda espécie), que possui uma dinâmica diferente daquelas presentes no TASEP simples. Propomos aqui que, uma interpretação da posição microscópica dos choques observados em processos do tipo TASEP como correspondendo a posição da vesícula lipídica, é capaz de explicar o movimento bidirecional destas vesículas como um estado transiente da dinâmica do sistema. Além disso, consideramos que a interação da vesícula com o filamento causa uma perturbação na densidade de "motores livres" (não associados à vesícula) que se movia sobre este filamento; a condição inicial considerada será então associada a esta perturbação. A aproximação dos modelos do tipo ASEP/TASEP tomando o limite do contínuo, descrita no Capítulo 3, nos permite estudar os estados transientes, e não apenas os estados estacionários como o método exato descrito por Derrida et al. [34], [35]. Com o estudo destes estados, conseguimos descrever um movimento bidirecional para os choques presentes no sistema.

No quinto capítulo são discutidos os resultados obtidos no quarto capítulo, comparando o movimento descrito para os choques com os parâmetros dos movimentos de vesículas lipídicas descritos nos experimentos que revisamos no segundo capítulo. 


\section{Capítulo 1}

\section{Modelos Mínimos para Motores Moleculares}

Quando buscamos entender como funciona um motor molecular, estamos de fato interessados na dinâmica do sistema composto por uma proteína motora, pelo filamento proteico e por todas as moléculas que interagem com eles, como o ATP e a água. Esta dinâmica tem sido estudada através de três abordagens, conhecidas como Dinâmica Molecular, Modelos Cinéticos e Modelos do tipo Markov-Fokker-Planck [39], que descreveremos brevemente a seguir.

A descrição mais completa possível desta dinâmica seria aquela onde se acompanha o movimento contínuo do sistema no espaço das possíveis configurações, que pode ser entendido como o movimento de uma partícula sobre uma superfície de energia potencial (energie landscape) em um espaço de $3 \mathrm{~N}$ dimensões (onde $\mathrm{N}$ é o número de átomos do sistema). A abordagem que mais se aproxima desta descrição completa, que descreveria o movimento contínuo de cada átomo, levando em conta todas as possíveis interações entre os átomos, através da superfície potencial, é aquela dada pela chamada Dinâmica Molecular [40]. Nessa estratégia busca-se a resolução numérica do sistema de equações diferenciais acopladas composto pelas equações clássicas de movimento para cada átomo do sistema. Uma dificuldade consiste no fato de que as forças de interação entre os átomos são normalmente descritas apenas de modo empírico ou semi-empírico, não se conhece o real potencial de interação entre os átomos do sistema. Entretanto, o que mais parece limitar o uso desta abordagem é o enorme desafio computacional, uma vez que os tempos de simulação necessários crescem exponencialmente com o tamanho do sistema simulado. Até o momento, o máximo que se consegue estudar com Dinâmica Molecular são sistemas da ordem de $10^{5}$ átomos e tempos da ordem de centenas de nanosegundos [40], [41]. No estudo do transporte intracelular mediado por motores moleculares, o sistema em questão, contendo a proteína motora, o filamento proteico, moléculas de ATP e de água e íons, tem um número da ordem de $10^{6}$ átomos e o movimento que nos interessa 
Tabela 1.1: Estados catalíticos de uma ATPase.

\begin{tabular}{|c|c|}
\hline Símbolo & Descrição \\
\hline$(\mathrm{E})$ & Enzima sem substrato \\
$(\mathrm{T})$ & Enzima liga ao ATP \\
$(\mathrm{DP})$ & Enzima ligada a ADP e Pi (produtos da hidrólise) \\
$(\mathrm{D})$ & Enzima ligada apenas ao ADP \\
\hline
\end{tabular}

dura tempos da ordem de milisegundos. Portanto, dadas as dimensões do sistema, a aplicação de Dinâmica Molecular no estudo destes sistemas ainda não é capaz de fornecer respostas acerca de fenômenos na escala de tempo e espaço em que estamos interessados. Não nos aprofundaremos mais na abordagem por Dinâmica Molecular e nesse trabalho vamos nos dedicar sobretudo ao tratamento do fenômeno de transporte intracelular por meio de modelos teóricos que apresentem solução analítica, faremos eventualmente uso de simulações computacionais apenas para estender soluções analíticas para situações gerais.

Outra abordagem no estudo dos motores moleculares é a abordagem cinética, derivada do tratamento usualmente dado às reações químicas. Esta foi a primeira abordagem teórica aplicada às proteínas motoras, como uma extensão ao tratamento originalmente dado para outras ATPases como as bombas iônicas [20], [21]. Assume-se que as configurações do sistema possam ser descritas por um pequeno número de estados discretizados do sistema, normalmente escolhidos por serem relativamente estáveis em ensaios bioquímicos. Para as ATPases, assim como para as bombas iônicas e as proteínas motoras, estes estados são quase sempre aqueles dados pela ocupação do sítio catalítico dos motores, como mostra a Tabela 1.1.

A dinâmica, nestes modelos puramente cinéticos, é dada por transições markovianas entre estes estados. Do ponto de vista microscópico, estamos assumindo que o sistema passa a maior parte do tempo transitando entre estados conformacionais relativamente próximos, localizados no fundo de um mesmo poço da superfície de energia potencial, podendo ser todos representados por um mesmo estado bioquímico discreto. Assume-se que entre tais estados discretos exista uma grande barreira potencial que, portanto, só seria ultrapassada raramente e de modo abrupto, o que explica a estabilidade que estes estados apresentam em ensaios bioquímicos. A dinâmica do sistema é dada pela equação mestra para a probabilidade de ocupação de cada estado:

$$
\frac{d \mathbf{p}}{d t}=\mathbf{K} \mathbf{p}
$$

onde $\mathbf{p}$ é o vetor normalizado que contém as probabilidades de ocupação de cada estado e K é a matriz de transição na qual os elementos fora da diagonal $k_{\alpha \alpha^{\prime}}$ são as taxas de transição entre os estados $\alpha$ e $\alpha^{\prime}$, e os elementos diagonais são dados por $k_{\alpha \alpha}=-\sum_{\alpha^{\prime} \neq \alpha} k_{\alpha^{\prime} \alpha}$, uma vez que esta é a chamada matriz de evolução do sistema [42]. 
Nesses primeiros modelos, o movimento do motor sobre o filamento é aferido assumindose que, a cada ciclo hidrolítico realizado pela enzima, um passo é dado na direção certa, ou seja, assume-se o movimento vetorial a priori e não se descreve explicitamente as coordenadas mecânicas (espaciais) do sistema. Vale notar que tal abordagem é bastante razoável para o estudo de bombas iônicas que realizam o transporte de íons através das membranas celulares, uma vez que tais bombas também são ATPases e, ao contrário dos motores, não se deslocam espacialmente (não apresentam movimento de translação do seu centro de massa). Entretanto, na aplicação desta abordagem à dinâmica de motores moleculares, esbarra-se num novo problema pois assume-se, a princípio, uma dissociação completa entre os graus de liberdade químicos e os espaciais (como a posição do motor no filamento). Em geral, nesses modelos, a matriz de transição é obtida empiricamente e, portanto, com este tipo de abordagem não se consegue informação alguma sobre como o sistema, partindo de princípios físicos que regem as interações entre seus átomos, consegue se manter num estado de não-equilíbrio termodinâmico e nele realizar trabalho mecânico.

Entre a abordagem puramente cinética, que trata a dinâmica do sistema considerando apenas transições entre um pequeno número de estados configuracionais discretos, e a modelagem molecular, que considera o movimento contínuo de cada átomo regido pelas forças de interação entre eles, existe uma terceira alternativa. Nesta nova abordagem, procura-se caracterizar espacialmente o sistema por um número reduzido de coordenadas coletivas, sendo ignorados os graus de liberdade que, a partir de justificativas físicas razoáveis (como dados sobre a simetria do sistema), possam ser considerados irrelevantes. Considera-se as forças mecânicas que atuam sobre o centro de massa do motor (dadas principalmente pela interação entre a proteína motora e o filamento), projetadas nestas coordenadas, possam ser descritas por uma superfície de energia potencial, definida para cada estado químico do sistema. A interação com o meio é considerada através de um ruído térmico (derivada de um processo de Wiener) e um ruído atérmico, representando a reação de hidrólise do ATP (mantida fora de equilíbrio no meio intracelular), que faz com que o sistema mude abruptamente de estado químico (esta é a mesma mudança de estado vista nos modelos cinéticos — ver estados catalíticos na Tabela 1.1). Nesse tipo de modelo, a mudança de estado químico do motor se reflete como uma mudança abrupta da superfície potencial considerada (o que é razoável, uma vez que a mudança da proteína motora deve se refletir na interação desta com o filamento). Com isso, consegue-se dar um tratamento contínuo para as coordenadas mecânicas (espaciais) do sistema reduzido (composto apenas pela proteína motora e pelo filamento proteico), enquanto as transições entre alguns dos estados quimicamente distintos continuam tratadas cineticamente. De fato, considera-se aqui a difusão de uma partícula sobre uma superfície potencial que muda no tempo: a partícula representa a proteína motora, a superfície potencial sua interação com o filamento, a difusão inclui todas as interações com o meio aquoso e a variação do potencial representa as mudanças de estado da proteína motora que ocorrem pelo acoplamento desta com reações químicas fora de equilíbrio. 
A princípio, dada a superfície potencial, o tratamento contínuo das coordenadas espaciais pode ser feito através da equação de Langevin. O meio intracelular é altamente viscoso, de modo que efeitos inerciais no movimento das proteínas duram apenas tempos da ordem de nanossegundos (ou seja, esta é a escala de tempo que o movimento das proteínas motoras leva para perder efeitos de inércia devido ao atrito com o meio). Como estamos interessados em um movimento que leva tempos da ordem de milissegundos, o termo inercial da equação de Langevin pode ser desprezado [39] e a dinâmica estocástica do motor molecular fica dada pela equação de Langevin super-amortecida:

$$
\zeta \frac{d x}{d t}=-\frac{\partial U^{j}(x)}{\partial x}+F+\sqrt{2 k_{B} T \zeta} f(t)
$$

onde $U^{j}(x)$ é a superfície potencial correspondente ao estado químico $j, x$ é a coordenada espacial, $t$ é o tempo e $\zeta$ é o coeficiente de atrito viscoso do meio, relacionado ao coeficiente de difusão $D$ pela relação de Einstein: $\zeta=k_{B} T / D\left(k_{B}\right.$ é a constante de Boltzmann e $T$ a temperatura absoluta). $F$ é uma eventual força externa constante, contra a qual o motor realiza trabalho, e $f(t)$ é o ruído branco. Aqui consideramos apenas uma coordenada espacial relevante $(x)$, mas este número poderia ser maior e teríamos então uma equação para o vetor composto por todas essas coordenadas.

Assim, temos uma dinâmica dada pela solução das equações contínuas ao longo das coordenadas geométricas e por saltos markovianos entre os potenciais que representam estados quimicamente diferentes. Por normalmente estarmos interessados em valores médios, em geral estes estudos são realizados através da solução da equação de Fokker-Planck associada a equação de Langevin (ver equação (1.23) abaixo) e, por isso, esta abordagem foi chamada de Markov-Fokker-Planck (MFP) [39]. Tanto no tratamento cinético como no MFP busca-se quase sempre a solução para estados estacionários do sistema (ou seja, os termos das equações (1.1) e (1.2) ou mesmo da equação (1.23) que incluem derivadas no tempo são anulados), os estados transitórios pelos quais o sistema passa são, portanto, ignorados na maioria dos estudos. Com o objetivo de ilustrar como esses modelos conseguem explicar o movimento vetorial de um motor molecular sobre um filamento a partir de princípios físicos relativamente simples e gerais, revisaremos a seguir dois desses modelos teóricos encontrados na literatura. Por movimento vetorial entende-se qualquer movimento direcionado, não aleatório, de uma partícula que, por apresentar esse tipo de movimento que possibilita a realização de trabalho mecânico, é chamada de partícula motora. Como a característica principal nesse tipo de estudo é mostrar quais os ingredientes mínimos necessários para se construir um sistema em que uma partícula seja capaz de realizar trabalho mecânico, isto é, um motor molecular, chamaremos esses modelos de "modelos mínimos para um motor molecular". Eles foram escolhidos principalmente por apresentar soluções analíticas, pelo menos dentro do limite adiabático (o qual será discutido adiante).

O primeiro desses modelos foi apresentado por Adjari e Prost [22] e, por supor um sistema físico bastante simples, ilustra de modo claro como o movimento direcionado de uma 
partícula pode ser obtido a partir de princípios físicos elementares. Entretanto, apesar de se ater aos princípios físicos básicos do sistema, este modelo visa também uma aplicação tecnológica (o estabelecimento de um método de separação de partículas com base no tamanho destas) e não somente a descrição teórica do movimento de motores biológicos. Assim, optamos por tratar em maior detalhe o modelo proposto por Astumian [26]. Esse segundo modelo que revisamos aqui é mais interessante do ponto de vista biológico por ter maior correspondência com aspectos bioquímicos das proteínas motoras, como o fato de apresentar quatro estados estáveis, o que torna este modelo um pouco mais complexo. $\mathrm{O}$ modelo proposto por Astumian é inicialmente tratado com uma abordagem do tipo MFP e posteriormente, para que se obtenha uma solução analítica, opta-se pela abordagem

cinética. A conexão entre estas abordagens é feita tomando-se o limite adiabático, que consiste em assumir que o sistema permanece num dado estado químico tempo suficiente para entrar em equílibrio termodinâmico com a superfície potencial que representa tal estado, ou seja, supõe-se equilíbrio local num dado poço da superfície potencial.

Como, para se obter uma solução analítica, ambos os modelos são tratados apenas no limite adiabático, apresentamos, no fim deste capítulo, um estudo computacional realizado em colaboração com o Professor Nestor F. Caticha, do Departamento de Física Geral deste Instituto, para o modelo proposto por Astumian. Neste estudo, foi realizada uma simulação numérica, a partir da equação de Langevin (dentro da descrição MFP), que nos permite observar como se comporta a dinâmica deste sistema dentro e fora do limite adiabático. Os resultados obtidos com essa simulação, quando se está no regime adiabático, estão de acordo com os resultados analíticos apresentados por Astumian e revisados aqui. Com a revisão destes dois modelos e em especial com o estudo aprofundado do modelo proposto por Astumian esperamos, além de ilustrar uma importante abordagem teórica dada pela física para o fenômeno de transporte molecular, esclarecer como são possíveis os fenômenos de movimento vetorial de moléculas num ambiente com ruído térmico importante, bastando, para isso, que uma assimetria esteja presente no sistema e que este esteja fora de equilíbrio termodinâmico.

\subsection{Modelo para um motor molecular proposto por Adjari e Prost}

Adjari e Prost, em um artigo de 1993 [22], propõem um modelo bastante elementar para um motor molecular artificial, que seria capaz de separar moléculas com base em seus tamanhos de modo eficaz. Não estamos interessados aqui nas possíveis aplicações tecnológicas deste modelo, mas no modelo em si, que é bastante geral e, por sua simplicidade, nos servirá de base para o entendimento dos princípios básicos que estão presentes em todos os modelos que buscam explicar o funcionamento de uma partícula motora. Faremos 


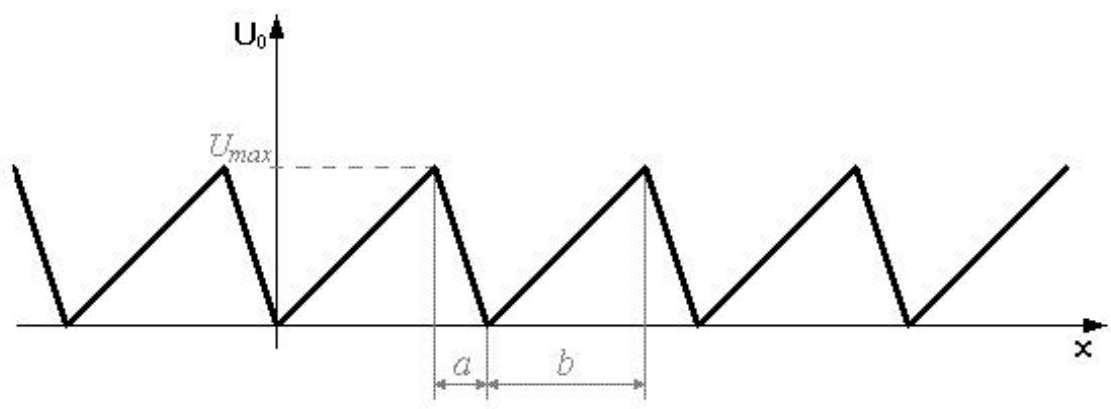

Figura 1.1: Modelo de potencial periódico assimétrico "dente-de-serra". O Potencial $U_{0}$ é parametrizado pelos valores de $a, b$ e $U_{\text {max }}$, sendo $a$ a distância entre um mínimo local e o máximo a sua esquerda e $b$ a distância entre um mínimo e o máximo a sua direita, $U_{\max }$ é o valor máximo que o potencial atinge.

aqui uma breve revisão deste artigo que, esperamos, sirva de base para uma compreensão intuitiva de modelos um pouco mais complexos como o que trataremos em seguida, ainda neste capítulo, proposto por Astumian [26]. Este modelo também servirá de base para, no Capítulo 3, fazermos uma conexão entre os modelos para o movimento de uma partícula motora e aqueles do tipo ASEP e TASEP, que incluem muitas partículas e assumem uma visão mais macroscópica do sistema.

O modelo proposto por Adjari e Prost trata a interação da partícula motora com o meio através de um potencial do tipo "dente-de-serra" (ver Figura 1.1). Este potencial seria aproximadamente aquele percebido por uma partícula carregada eletricamente, frente a uma cadeia uniforme de dipolos, espaçados de modo que a distância entre uma carga negativa e a carga positiva a sua direita seja diferente da sua distância à carga positiva a sua esquerda. Este talvez seja o exemplo mais simples de um potencial periódico e assimétrico. Estas são características básicas que o potencial deve apresentar se esperamos gerar com ele um movimento direcionado (que chamamos aqui de movimento vetorial), de escala macroscópica, de uma partícula microscópica. A assimetria do sistema é obviamente necessária para que o movimento seja assimétrico e a periodicidade é necessaria para que o movimento microscópico de uma molécula se propague, atingindo escalas macroscópicas. Estas são também as características apresentadas, em última análise, pelos filamentos proteicos sobre os quais se dá o movimento das proteínas motoras, uma vez que tais proteínas são carregadas eletricamente (apesar de terem uma distribuiçãos de cargas bastante complexa em sua superfície) e os filamentos são polímeros proteicos regulares (e portanto periódicos) sendo cada monômero uma unidade proteíca assimétrica morfológica, química e eletricamente (apresentando pelo menos um momento de dipolo diferente de zero).

Para que a partícula motora se mova vetorialmente (de modo direcionado, assimétrico), 
é necessário que o sistema se encontre fora de equilíbrio termodinâmico, de modo a não violar a segunda lei da termodinâmica. Este modelo coloca o sistema fora de equilíbrio através de um ruído atérmico que se expressa pela aplicação, de modo intermitente, do potencial "dente-de-serra" descrito acima, ou seja, este potencial atua sobre a partícula motora em pulsos de duração $\tau_{2}$ separados por períodos de duração $\tau_{1}$ em que a partícula se difunde livremente $(U=0)$. Para que se obtenha uma solução analítica, o modelo é tratado apenas no regime adiabático, no qual a magnitude do potencial aplicado e o período $\tau_{2}$ são tais que, a cada pulso, a partícula fica presa ao fundo de um poço e não sai dele até o final deste pulso ( $\tau_{2}$ é grande o suficiente para que a partícula que se encontra sob a região de ação de um dado poço do potencial quando o potencial "dente-de -serra" é ligado, atinja o fundo deste poço, mas é menor que o tempo de escape de um poço, da partícula, devido a agitação térmica). Deste modo a única consideração sobre a magnitude do poço $\left(U_{\max }\right)$ é que seja razoavelmente maior que $k_{B} T$.

O potencial considerado é, então, dado por:

$$
\begin{aligned}
& U(x, t)=0 \text { para } n\left(\tau_{1}+\tau_{2}\right) \leqq t \leqq n\left(\tau_{1}+\tau_{2}\right)+\tau_{1} \quad n=0,1,2, \ldots \\
& U(x, t)=U_{0}(x) \text { para o caso contrário. }
\end{aligned}
$$

onde $U_{0}(x)$ está representado na Figura 1.1, na qual os parâmetros $a, b$ e $U_{\max }$ encontramse definidos.

Durante o intervalo de tempo $\tau_{1}$, a partícula está sujeita ao ruído térmico do meio, se difundindo simetricamente a partir da posição do fundo do poço em que ela se encontrava no pulso anterior. Torna-se fácil ver qualitativamente como o movimento vetorial é gerado neste modelo. Quando o potencial é ligado a partícula fica presa num poço, a partir do qual se difunde simetricamente quando o potencial é desligado. Já quando o potencial é ligado novamente, devido a sua assimetria, a partícula tem maior probabilidade de ficar retida num poço à esquerda do poço inicial do que num poço à direita deste (se consideramos $a<b$, como no potencial da Figura 1.1), o que gera o movimento assimétrico. É intuitivo também o fato dessa assimetria no movimento ser maior quanto mais assimétrico for o potencial (quanto maior for a diferença entre $a$ e $b$, maior a probabilidade da partícula, a cada período de oscilação do potencial, ir para poços à esquerda em relação aos da direita).

Do ponto de vista energético, o ruído atérmico mantém o sistema fora de equilíbrio termodinâmico, fornecendo energia à partícula: quando o potencial "dente-de-serra" é ligado a partícula ganha energia potencial (que depende da sua posição relativa ao fundo do poço) que será em seguida dissipada pelo atrito com o meio conforme ela é empurrada pelo potencial para o fundo do poço. É parte desta energia dissipada que eventualmente pode ser utilizada na geração de trabalho mecânico.

Passemos agora a solução analítica deste modelo, que consiste em descrever como será 
o movimento da partícula. Dada a aproximação adiabática, a cada pulso a partícula é atraída para o mínimo local do potencial, cuja zona de atração (dimensão do "poço") engloba a posição da partícula. Em seguida, quando o potencial é desligado, a partícula difunde-se livremente a partir daí, por um intervalo de tempo $\tau_{1}$, de modo a atingir uma posição $z$, a partir do fundo do poço em que ela estava, com probabilidade dada pela distribuição gaussiana:

$$
p(z)=\left(4 \pi D^{0} \tau_{1}\right)^{-1 / 2} \exp \left(-\frac{z^{2}}{4 D^{0} \tau_{1}}\right)
$$

Esta distribuição tem média zero, uma vez que a difusão durante este período é simétrica, e variância $2 D^{0} \tau_{1}$ onde $D^{0}$ é o coeficiente de difusão microscópico dado por $D^{0}=2 k_{B} T / \zeta$ onde $k_{B}$ é a constante de Boltzmann, $T$ a temperatura absoluta e $\zeta$ é o coeficiente de atrito da partícula no meio.

Para estudarmos o deslocamento macroscópico da partícula podemos olhar o seu movimento como uma caminhada aleatória unidimensional em que cada sítio da rede representa um dos poços do potencial dente-de-serra e cada passo $i$ representa o processo que ocorre em um período de oscilação do potencial $\left(\tau_{1}+\tau_{2}\right)$. Definimos então a seqüência de variáveis aleatórias $\sigma_{i}, i=1,2, \ldots$ que são igualmente distribuídas e assumem valores $m=0, \pm 1, \pm 2, \ldots$ de acordo com a seguinte distribuição de probabilidades:

$$
P\left(\sigma_{i}=m\right)=\int_{b+(m-1)(a+b)}^{b+m(a+b)} p(z) d z .
$$

A variável $\sigma_{i}$ indica o sítio atingido pela partícula após cada passo $i$, que deve coincidir então com um dos mínimos do potencial ao ser ligado novamente. A seqüência $X_{i}=$ $(a+b) \sigma_{i}$ indica a correspondente posição $x_{i}=(a+b) m$ da partícula em relação à origem definida no passo anterior. Após $n$ passos, a posição da partícula será dada pela variável $l_{n}$ definida pela soma:

$$
l_{n}=\sum_{i=1}^{n} x_{i}=(a+b) \sum_{i=1}^{n} \sigma_{i}
$$

As variáveis $X_{i}$ são independentes e igualmente distribuidas e, se o número de passos for grande, resulta, do teorema central do limite, que a distribuição de probabilidade da variável $l_{n}$ é dada por uma gaussiana de média $n<X>$ e variância $n\left(<X^{2}>\right.$ $-<X>^{2}$ ), onde eliminamos o sub-indice $i$. Assim, após um tempo $t=n\left(\tau_{1}+\tau_{2}\right)$, temos um movimento que pode ser visto como uma difusão assimétrica "macroscópica" da partícula:

$$
P\left(l_{n}\right)=\left[2 \pi D_{m} n\left(\tau_{1}+\tau_{2}\right)\right]^{-1 / 2} \exp \left(-\frac{l_{n}-n<X>}{2 D_{m} n\left(\tau_{1}+\tau_{2}\right)}\right)
$$

e portanto fica caracterizado por uma velocidade média $V_{m}$ e um coeficiente de difusão 
$D_{m}$ "macroscópicos" dados por:

$$
\begin{aligned}
V_{m} & =\frac{<X>}{\left(\tau_{1}+\tau_{2}\right)} \\
D_{m} & =\frac{\left(<X^{2}>-<X>^{2}\right)}{2\left(\tau_{1}+\tau_{2}\right)}
\end{aligned}
$$

Estas duas grandezas devem ser obtidas em termos dos parâmetros microscópicos $D^{0}, a$ e $b$ a partir dos dois primeiros momentos da distribuição $P(m)$ definida em (1.6):

$$
\begin{aligned}
<X> & =\sum_{m=-\infty}^{\infty} m(a+b) P(m) \\
<X^{2}> & =\sum_{m=-\infty}^{\infty} m^{2}(a+b)^{2} P(m)
\end{aligned}
$$

Para conseguir uma solução analítica no cálculo destes momentos, como indicado no trabalho de Adjari e Prost ([22]), podemos considerar dois casos extremos quanto à velocidade de difusão da partícula motora durante o intervalo de tempo $\tau_{1}$. Estes dois casos são identificados analisando-se a relação entre o coeficiente de difusão microscópico $\left(D^{o}\right)$ e o tamanho dos poços $(a+b)$. No regime de difusão rápida, a cada período $\left(\tau_{1}+\tau_{2}\right)$ a partícula se difunde livremente por um grande número de poços, enquanto no regime de difusão lenta, a partícula se difunde no máximo o suficiente para chegar ao poço vizinho, à direita ou à esquerda.

- Regime de difusão rápida: Este regime é caracterizado por um desvio quadrático durante a difusão livre da partícula muito maior que o tamanho de cada poço, ou seja, $\left(2 D^{0} \tau_{1}\right) \gg(a+b)^{2}$. Neste caso, podemos aproximar a integral no cálculo da distribuição $P(m)$ pela área do trapézio compreendido entre os extremos:

$$
\begin{aligned}
P(m) & =\int_{b+(m-1)(a+b)}^{b+m(a+b)} p(x) d x \\
& \cong \frac{p[b+m(a+b)]+p[b+(m-1)(a+b)]}{2}\{[b+m(a+b)]-[b+(m-1)(a+b)]\} \\
& =\frac{(a+b)}{2}\left(4 \pi D^{0} \tau_{1}\right)^{-1 / 2}\left[\exp \left(-\frac{b+(m-1)(a+b)}{4 D^{0} \tau_{1}}\right)+\exp \left(-\frac{b+m(a+b)}{4 D^{0} \tau_{1}}\right)\right]
\end{aligned}
$$

Queremos calcular $\langle X\rangle$ definido na equação (1.10). Para isto deve-se notar que, pelo fato de neste regime a partícula poder atravessar um número grande de sítios em cada passo, a maior contribuição para a somatória em (1.10) vem de valores grandes de $m$ e, portanto, se tomarmos os limites $m \rightarrow \infty$ e $(a+b) \rightarrow 0$, a variável $x=m(a+b)$ assume valores contínuos e esta somatória converge para uma integral:

$$
<X>=\sum_{m=-\infty}^{\infty} m(a+b) P(m) \cong 1 /(a+b) \int_{-\infty}^{\infty} x P(x /(a+b)) d x .
$$


Substituindo o resultado obtido em (1.12) na expressão acima, temos:

$$
\begin{gathered}
<X>=\frac{1}{2\left(4 \pi D^{0} \tau_{1}\right)^{-1 / 2}} \int_{-\infty}^{\infty} x\left[\exp \left(-\frac{(x-a)^{2}}{4 D^{0} \tau_{1}}\right)+\exp \left(-\frac{(x+b)^{2}}{4 D^{0} \tau_{1}}\right)\right] d x \\
=\frac{(a-b)}{2}
\end{gathered}
$$

de onde:

$$
V_{m}=\frac{(a-b)}{2\left(\tau_{1}+\tau_{2}\right)}
$$

Como a variância de $x$ é $2 D^{0} \tau_{1}$,

$$
\begin{gathered}
<l^{2}>-<l>^{2}=n\left(<X^{2}>-<X>^{2}\right)=2 n D^{0} \tau_{1} \\
=2 D^{0} \tau_{1}\left(\frac{t}{\left(\tau_{1}+\tau_{2}\right)}\right)=2 D_{m} t
\end{gathered}
$$

e obtemos

$$
D_{m}=\frac{D^{0} \tau_{1}}{\left(\tau_{1}+\tau_{2}\right)}
$$

- Regime de difusão lenta: Este regime é caracterizado por um desvio quadrático no movimento de difusão livre menor do que a diferença entre as distâncias do fundo de um poço e os poços à direita e à esquerda, ou seja, $\left(2 D^{0} \tau_{1}\right) \ll(b-a)^{2}$. Como neste caso a partícula ou fica parada ou se move apenas o suficiente para alcançar o poço à esquerda, temos uma distribuição binomial:

$$
P(m) \cong \delta_{m,-1} p+\delta_{m, 0}(1-p)
$$

onde $\delta_{m, n}$ é a função delta de Dirac (igual a 1 se $m=n$ e 0 caso contrário), e

$$
p \cong 1 / 2 \Phi\left[a /\left(4 D^{0} \tau_{1}\right)^{1 / 2}\right]
$$

onde $\Phi$ é a função erro dada por:

$$
\Phi(x)=2 / \sqrt{\pi} \int_{x}^{\infty} e^{-y^{2}} d y
$$

Assim:

$$
\begin{gathered}
V_{m}=\frac{-p(a+b)}{\left(\tau_{1}+\tau_{2}\right)} \\
D_{m}=\frac{p(1-p)(a+b)^{2}}{2\left(\tau_{1}+\tau_{2}\right)} .
\end{gathered}
$$

Vemos que, apesar de apresentarem comportamentos bastante diferentes, ambos os regimes resultam em valores não nulos para $V_{m}$, negativos em ambos os casos se $a<b$, o que está de acordo com nossa análise qualitativa inicial. Isto indica que este tipo de mecanismo 
proposto por Adjari e Prost (também estudado por outros autores como Manhasco [23]), descreve bastante bem, ao menos qualitativamente, o movimento assimétrico observado para uma partícula Browniana e explica a realização de trabalho mecânico pelo sistema. A análise das diferenças no comportamento entre os dois regimes é mais explorada no artigo de Adjari e Prost [22], mas, por não estarmos interessados em aplicações tecnológicas desse modelo, dispensaremos maiores comentários a este respeito.

\subsection{Modelo para um motor molecular proposto por Astumian}

O modelo proposto por Astumian [26] busca descrever a realização de trabalho pela dinâmica do sistema composto por uma partícula browniana que interage, através de forças Van der Walls e interações hidrofóbicas, com um filamento unidimensional (composto de unidades proteicas idênticas porém assimétricas), num ambiente aquoso isotérmico. Dentro da abordagem MFP, descrita no início deste capítulo, imagina-se um perfil de energia potencial que corresponda à força percebida pelo centro de massa da partícula devido à interação com o filamento. Esta superfície de energia potencial deve ser periódica e assimétrica (anisotrópica, sem plano de simetria), dadas as características do filamento (como foi dito na introdução e no início da seção anterior, o filamento é normalmente um polímero proteico, no qual cada monômero é uma proteína globular assimétrica tanto morfológica como química e eletricamente). Como vimos na revisão do modelo de Adjari e Prost (seção anterior) o potencial mais simples que possui estas características é o potencial tipo "dente-de-serra" e, de fato, poderia ter sido deste tipo o potencial escolhido por Astumian. Entretanto, como veremos adiante, Astumian prefere escolher para o seu modelo um potencial que seja um pouco mais complexo, mas que permita uma conexão mais intuitiva entre os quatro estados catalíticos apresentados pelo motor (ver Tabela 1.1) e os poços de estabilidade apresentados pelo potencial. O filamento é considerado unidimensional, como no modelo da seção anterior, e todas as coordenadas mecânicas do sistema são então projetadas sobre a coordenada $x$, que descreve a posição do centro de massa do motor sobre o filamento (assim, a superfície potencial torna-se um perfil potencial). Considera-se que a partícula não seja capaz de afastar-se do filamento, movendo-se apenas sobre ele, de acordo com mudanças conformacionais que surjam em função do ruído browniano e levam à formação e destruição de pontos de contato entre a partícula e o filamento. O problema é então descrito em termos da difusão de uma partícula sobre uma superfície potencial periódica e assimétrica. Ocasionalmente ocorre uma transição através da barreira que separa dois poços do potencial, representando a transição da partícula para o monômero seguinte do filamento. Se o sistema estiver em equílibrio termodinâmico, o número de transições para a direita e para a esquerda serão iguais em média e não ocorrerá movimento vetorial nem realização de trabalho mecânico. 


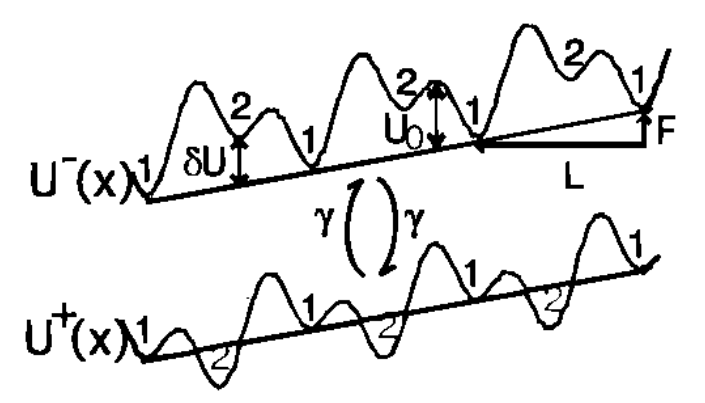

Figura 1.2: Potencial periódico e assimétrico que oscila com freqüência $\gamma$ entre dois estados $U^{+}(x)$ e $U^{-}(x)$. F é uma força externa constante, de direção contrária ao movimento gerado pelo potencial oscilatório, que pode eventualmente estar presente. Fonte: Astumian (1996) [26].

Conforme dissemos anteriormente, para que o sistema seja capaz de realizar trabalho sem que se viole a segunda lei da termodinâmica, um processo fora de equilíbrio deve estar acoplado ao sistema. Quase invariavelmente, no meio intracelular, o processo associado que mantém o sistema fora de equilíbrio termodinâmico é a reação de hidrólise do ATP. A princípio, poderia-se imaginar uma superfície potencial diferente para cada um dos estados químicos por que passa o motor ao longo do cíclo catalítico da hidrólise (ver Tabela 1.1 no início deste capítulo), com a transição entre elas ocorrendo de modo estocástico, de acordo com a ligação de ATP, conversão em ADP e Pi e liberação destes produtos da hidrólise. A energia fornecida por essa reação ao motor faz com que ele consiga assumir uma conformação termodinamicamente desfavorável, que no modelo está representada pela transição entre um estado de baixa energia numa dada curva para um estado de maior energia numa outra curva potencial.

Entretanto, se associassemos uma superfície potencial diferente para cada estado, não acoplaríamos as coordenadas mecânicas do sistema aos estados químicamente distintos. Buscando este acoplamento, Astumian opta em seu modelo por ter apenas duas superfícies potencias distintas $\left(U^{+}(x)\right.$ e $\left.U^{-}(x)\right)$, espacialmente periódicas, sendo que em cada período dessas superfícies há dois mínimos locais (poços 1 e 2) com energias diferentes, conforme ilustrado na Figura 1.2. Tem-se assim os quatro estados químicos do motor (ver Tabela 1.1) associados inderetamente aos poços $1^{+}, 1^{-}, 2^{+}$e $2^{-}$.

Temos então uma dinâmica dada pela difusão de uma partícula sobre uma superfície potencial que oscila entre dois possíveis estados $U^{+}(x)$ e $U^{-}(x)$. Numa abordagem contínua, deveríamos resolver a equação de Fokker-Planck associada à equação de Langevin (1.2):

$$
\frac{\partial \rho^{j}}{\partial t}=\frac{1}{D} \frac{\partial}{\partial x}\left(\frac{1}{k_{B} T}\left(-F+\frac{\partial U^{j}(x)}{\partial x}\right) \rho^{j}\right)+D \frac{\partial^{2} \rho^{j}}{\partial^{2} x}+\sum_{i} k_{j i}(x) \rho^{i}, \operatorname{com} j=+,-
$$

onde $\rho^{j}(x, t)$ é a densidade de probabilidade do motor estar no ponto $x$ no instante $t$ no estado químico $j$, e $k_{j i}$ são as taxas de transição entre as superfícies (que compõem 
a matriz $\mathbf{K}$ na equação (1.1), fica explícito aqui que o modelo representado na equação (1.23) mistura uma descrição cinética e uma contínua).

Entretanto, para tornar possível uma solução analítica, opta-se por uma descrição cinética deste modelo, considerando os poços 1 e 2 de cada superfície potencial (ou seja, os quatro estados $1^{+}, 1^{-}, 2^{+}$e $2^{-}$) como estados discretos do sistema. Os poços 1 e 2 representam estados distintos tanto química como espacialmente, enquanto a transição entre os estados $U^{+}$e $U^{-}$representa uma mudança química, sem associação com a posição do motor no filamento.

A transição entre as superfícies $U^{+}(x)$ e $U^{-}(x)$ corresponde normalmente a processos de natureza estocástica (como o encontro com o ATP), mas poderia também ser causada por um campo elétrico externo oscilante. Isto foi verificado experimentalmente com a geração de gradientes eletroquímicos por bombas iônicas ATPásicas submetidas a um campo elétrico oscilante, na ausência de ATP [43], [44]. A princípio, supomos que $\gamma_{i}^{+}$é a taxa com que ocorre a transição a partir do potencial $U^{+}(x)$ para o potencial $U^{-}(x)$ e $\gamma_{i}^{-}$a taxa com que ocorre a transição a partir do potencial $U^{-}(x)$ para o $U^{+}(x)$ no poço $i$ (vale lembrar que na aproximação adiabática a transição só ocorre com a partícula em algum mínimo local). Para que seja razoável substituirmos a descrição contínua, em termos da coordenada $x$, por uma discreta, considerando apenas os estados 1 e 2 para cada superfície, deve valer a aproximação adiabática, ou seja, os tempos de relaxação dentro dos poços devem ser menores que os tempos que o sistema passa num dado estado químico antes de alternar para o outro. Isso equivale a dizer que as taxas de transição $\gamma_{i}^{+}$ e $\gamma_{i}^{-}$devem ser baixas comparadas com o inverso do tempo de relaxação, o que pode ser estimado pela taxa $A_{i}=D / L_{i}^{2}$, onde $L_{i}$ é a distância entre os picos que limitam o poço $i$ e $D$ é o coeficiente de difusão [45]. É apenas no limite adiabático que a teoria de Kramer nos permite obter as taxas de transição entre os estados discretos a partir dos parâmetros da superfície potencial.

Para um caso geral, a teoria de Kramer nos diz que, se $\alpha_{i}$ é a taxa de transição do poço $i$ para o poço a sua direita $(i+1)$ e $\beta_{i}$ a taxa de transição deste poço $i$ para aquele a sua esquerda $(i-1)$, essas taxas são dadas por:

$$
\begin{aligned}
& \alpha_{i}=A_{i} e^{\Delta U d} \\
& \beta_{i}=A_{i} e^{\Delta U e}
\end{aligned}
$$

onde $\Delta U d$ e $\Delta U e$ são as diferenças entre a energia potencial no fundo do poço $i$ e a energia potencial no topo da barreira à direita e à esquerda deste poço, respectivamente, e $A_{i}$ é a taxa citada acima, que corresponde ao inverso do tempo médio necessário para o sistema varrer o poço $i$ da superfície potencial.

No caso do potencial representado na Figura 1.2, temos que a equação mestra (1.1) para 
a evolução do sistema fica:

$$
\frac{d}{d t}\left[\begin{array}{c}
p_{1}^{+} \\
p_{2}^{+} \\
p_{1}^{-} \\
p_{2}^{-}
\end{array}\right]=\left[\begin{array}{cccc}
\delta_{1}^{+} & \left(\alpha_{2}^{+}+\beta_{2}^{+}\right) & \gamma_{1}^{-} & 0 \\
\left(\alpha_{1}^{+}+\beta_{1}^{+}\right) & \delta_{2}^{+} & 0 & \gamma_{2}^{-} \\
\left(\gamma_{1}^{+}\right) & 0 & \delta_{1}^{-} & \left(\alpha_{2}^{-}+\beta_{2}^{-}\right) \\
0 & \gamma_{2}^{+} & \left(\alpha_{1}^{-}+\beta_{1}^{-}\right) & \delta_{2}^{-}
\end{array}\right]\left[\begin{array}{c}
p_{1}^{+} \\
p_{2}^{+} \\
p_{1}^{-} \\
p_{2}^{-}
\end{array}\right]
$$

onde

$$
\begin{aligned}
& \delta_{1}^{ \pm}=-\left(\alpha_{1}^{ \pm}+\beta_{1}^{ \pm}+\gamma_{1}^{ \pm}\right), \\
& \delta_{2}^{ \pm}=-\left(\alpha_{2}^{ \pm}+\beta_{2}^{ \pm}+\gamma_{2}^{ \pm}\right) .
\end{aligned}
$$

e, de acordo com a equação (1.24), as taxas são dadas por:

$$
\begin{gathered}
\alpha_{1}^{+}=\alpha_{2}^{-}=4 \exp \left(-U_{0}+\delta U+F / 4\right), \\
\alpha_{1}^{-}=\alpha_{2}^{+}=4 \exp \left(-U_{0}-\delta U+F / 4\right), \\
\beta_{1}^{+}=\beta_{1}^{-}=\beta_{2}^{+}=\beta_{2}^{-}=4 \exp \left(-U_{0}-F / 4\right),
\end{gathered}
$$

Aqui e no restante deste capítulo são consideradas unidades de energia tais que $k_{B} T=1$, unidades de comprimento tais que $L=1$, e unidades de tempo tais que o coeficiente de difusão $D=1$. Cabe aqui um parênteses: neste capítulo, sempre que nos referirmos aos termos partículas ou motores, no plural, estamos pensando estatisticamente (em termos de "emsemble"), ou seja, partículas não interagentes que obedecem à mesma dinâmica (no linguajar probabilístico elas seriam descritas como independentes e igualmente distribuídas). No segundo e sobretudo no terceiro capítulos isso não será necessariamente verdade, uma vez que trataremos de sistemas compostos de partículas interagentes.

Como, ao mudar do potencial $U^{+}$para o $U^{-}$, as partículas no poço 2 ganham $2 \delta U$ de energia enquanto aquelas no poço 1 não têm sua energia potencial alterada, uma flutuação de equilíbrio corresponderia às seguintes relações:

$$
\begin{gathered}
\gamma_{2}^{+} / \gamma_{2}^{-}=\exp (-2 \delta U) \\
\gamma_{1}^{+} / \gamma_{1}^{-}=1
\end{gathered}
$$

Com essas constantes na equação (1.25), no estado estacionário (obtido como solução da equação (1.25) para $d \mathbf{p} / d t=0)$, obtém-se probabilidades $p_{i}$ que satisfazem a lei de distribuição de Boltzmann e fluxo zero se a força externa $F=0$ (tem-se um fluxo no sentido desta força se $F \neq 0$ ). De fato, com as relações dadas pela equação (1.31) e pela equação (1.32), estaríamos satisfazendo as condições de balanceamento detalhado (reversibilidade microscópica). Entretanto, se temos flutuações que mantêm o sistema fora de equilíbrio (ou seja, com taxas tais que $\gamma^{+} / \gamma^{-} \neq \exp \left(U^{+}(x)-U^{-}(x)\right)$ ), como aquelas provocadas pela reação de hidrólise do ATP no meio intracelular, obtemos distribuições 


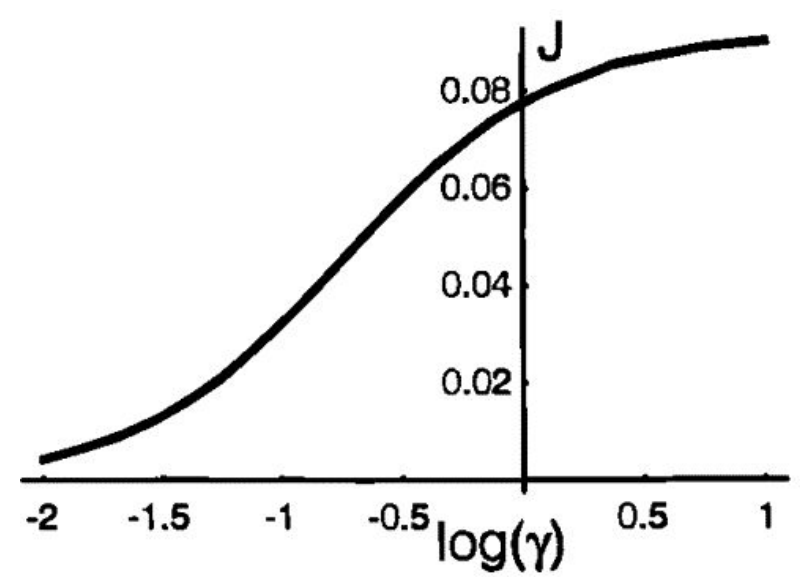

Figura 1.3: Fluxo $J(\gamma)$ de partículas como função do logarítmo da freqüência calculado para $F=0$. Fonte: Astumian (1996) [26].

que não obedecem à lei de Boltzmann e podemos ter um fluxo contra a força externa, com realização de trabalho mecânico.

Para facilitar os cálculos, Astumian considera o caso de taxas $\gamma_{i}^{+}=\gamma_{i}^{-}=\gamma$, para $i=1,2$. Temos então, no estado estacionário, as seguintes probabilidades para ocupação dos poços:

$$
\begin{aligned}
& p_{1}^{+}=p_{2}^{-}=\frac{\gamma+\left(e^{-F / 4}+e^{F / 4-\delta U}\right) e^{-U_{0}}}{4 \sum} \\
& p_{1}^{-}=p_{2}^{+}=\frac{\gamma+\left(e^{-F / 4}+e^{F / 4+\delta U}\right) e^{-U_{0}}}{4 \sum}
\end{aligned}
$$

onde

$$
\sum=\gamma+\left(e^{-F / 4}+\cosh (\delta U) e^{F / 4}\right) e^{-U_{0}}
$$

O fluxo de partículas no estado estacionário é aquele através da barreira entre os estados 1 e 2 , dado por $J=\alpha_{1}^{+} p_{1}^{+}+\alpha_{1}^{-} p_{1}^{-}-\beta_{2}^{+} p_{2}^{+}-\beta_{2}^{-} p_{2}^{-}$, que, substituindo as expressões obtidas na equação (1.33), fica:

$$
J=\left\{2 \gamma\left[e^{F / 4} \cosh (\delta U)-e^{-F / 4}\right]+4 e^{-U_{0}} \sinh (F / 2)\right\} \frac{e^{-U_{0}}}{4 \sum}
$$

Este fluxo, como função de $\log (\gamma)$, é mostrado na Figura 1.3, $\operatorname{com} F=0$. Como estamos considerando o estado estacionário do sistema, a densidade de partículas é constante e, portanto, o fluxo de partículas é uma medida direta da velocidade média das partículas pois, sendo $\rho$ a densidade de partículas e $v$ a velocidade, vale a relação:

$$
J=\rho v
$$

A energia introduzida por ciclo no sitema é $2 \delta U p_{2}^{+}$, ou seja, a potência gasta no sistema é dada por:

$$
P_{\text {in }}=\gamma 2 \delta U p_{2}^{+}
$$


Já o trabalho realizado por unidade de tempo, que inclui tanto aquele contra a força externa como aquele contra o atrito devido ao meio viscoso, é dado por:

$$
P_{\text {out }}=J F / 2+J^{2}
$$

Pelo fato da reação catalisada por esta enzima estar fora de equilíbrio termodinâmico no ambiente em questão, ela ocorre preferencialmente no sentido da hidrólise. Isto implica que a enzima cicla entre os estados bioquimicamente estáveis numa determinada ordem em preferencia à ordem inversa. Com o modelo ilustrado pela Figura 1.2, Astumian mostra como este ciclo pode ser traduzido em movimento vetorial por um motor molecular. A energia é introduzida no sistema para promover a transição do estado $2^{+}$para o estado $2^{-}$. Em seguida segue-se uma relaxação espontânea para o estado $1^{-}$, que ocorre predominantemente para a direita, dado a menor barreira potencial. Após a transição para o potencial $U^{+}$(desta vez sem custo energético), segue-se nova relaxação do estado $1^{+}$ para o $2^{+}$, que novamente ocorre predominantemente para a direita, de modo que agora o motor se encontra no monômero seguinte do filamento (um passo foi dado).

\subsection{Simulação do modelo de Astumian}

Desenvolvemos em conjunto com o Professor Dr. Nestor F. Caticha, do Departamento de Física Geral deste Instituto, um algorítmo computacional que simula o movimento de uma partícula browniana que segue a dinâmica proposta no modelo de Astumian (1996) [26] para um motor browniano clássico. As diferenças entre o modelo simulado e aquele proposto por Astumian resumem-se a pequenas modificações quanto à forma do potencial assimétrico, dado que este não é explicitado no artigo, mas deve ser descrito de forma analítica para que se realize a simulação.

Utilizamos a equação de Langevin (1.2) para simular a evolução temporal da posição da partícula sujeita ao potencial $U^{j}(x)$ de período $L$ (que oscila no tempo entre os estados $U^{+}(x)$ e $U^{-}(x)$ com freqüência $\gamma$ ), a uma força externa $F$ e ao ruído térmico transmitido pela força $f(t)$.

A forma analítica que adotamos para o potencial é a seguinte:

$$
\begin{aligned}
U^{+}(x) & =-5(2 \pi / L) \cos (2 \pi x / L) \\
& -5(4 \pi / L) \cos (4 \pi x / L-\pi / 6)-L F \\
U^{-}(x) & =-5(2 \pi / L) \cos ((x-L / 2) 2 \pi / L) \\
& -5(4 \pi / L) \cos (4(x-L / 2) \pi / L-\pi / 6)-L F
\end{aligned}
$$




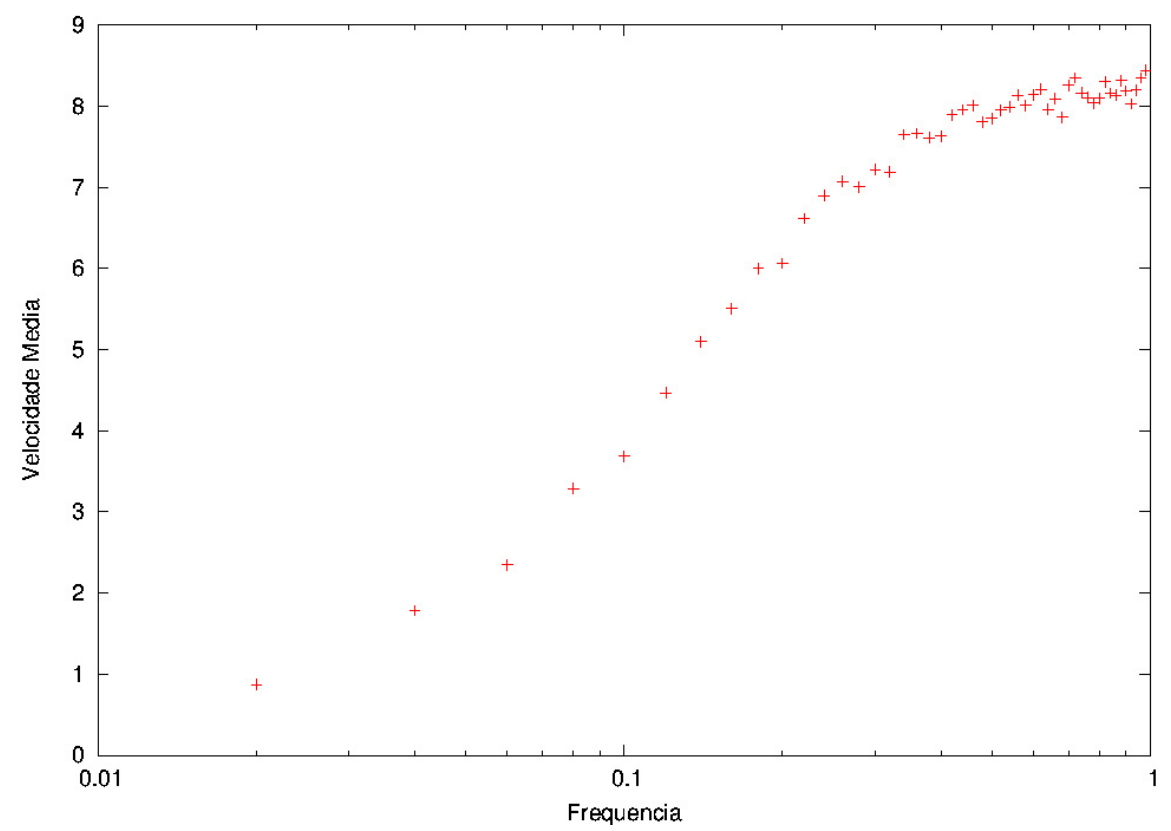

Figura 1.4: Velocidade média das partículas (proporcional ao fluxo pois assumiu-se uma densidade constante de partículas) em função da freqüência $\gamma$ (em escala logarítimica, de modo a permitir uma melhor comparação com a Figura 1.3) de oscilação do potencial, para baixas freqüências (dentro do limite adiabático). A força externa utilizada é nula $(F=0)$ e $k_{B} T=1$. As unidades utilizadas são arbitrárias e os valores mostrados são médias de 400 simulações.

O fluxo que obtivemos com nossa simulação para baixas freqüências $(\gamma<1)$ está mostrado na Figura 1.4, e se mostra em pleno acordo com o resultado analítico descrito acima (comparar com a Figura 1.3). Vemos que, para esta faixa de freqüências baixas, o fluxo de partículas aumenta com a freqüência até atingir um máximo.

Estudamos então, como varia o fluxo em função da freqüência para uma faixa grande de frequências (incluindo altas freqüências), ou seja, longe do limite adiabático (Figura 1.5). Uma vez atingida a freqüência que maximiza o fluxo, conforme a frequência aumenta, o fluxo começa a diminuir. Este comportamento era previsto, uma vez que os motores passam a não ter tempo suficiente para atingir o mínimo local do potencial antes que este oscile, tendendo a ficar estacionários num mesmo poço. Pode-se dizer que o que os motores "sentem", para altas freqüências, é a presença de um potencial estático médio.

Comparamos o comportamento do fluxo de partículas para diversas temperaturas do meio. Apesar de não apresentar interesse biológico evidente, esta análise é interessante tanto do ponto de vista físico como para possíveis aplicações destes modelos em nanotecnologia. Com temperaturas mais altas observa-se que o valor da freqüência que maximiza o fluxo de partículas aumenta. Isso pode ser interpretado pelo fato do limite adiabático ficar expandido (a condição $\gamma<A_{i}$, onde $A_{i}=D / L_{i}^{2}=k_{B} T / \zeta L_{i}^{2}$, vale para freqüências mais altas), o que é razoável, uma vez que a partícula browniana varre o poço num tempo 


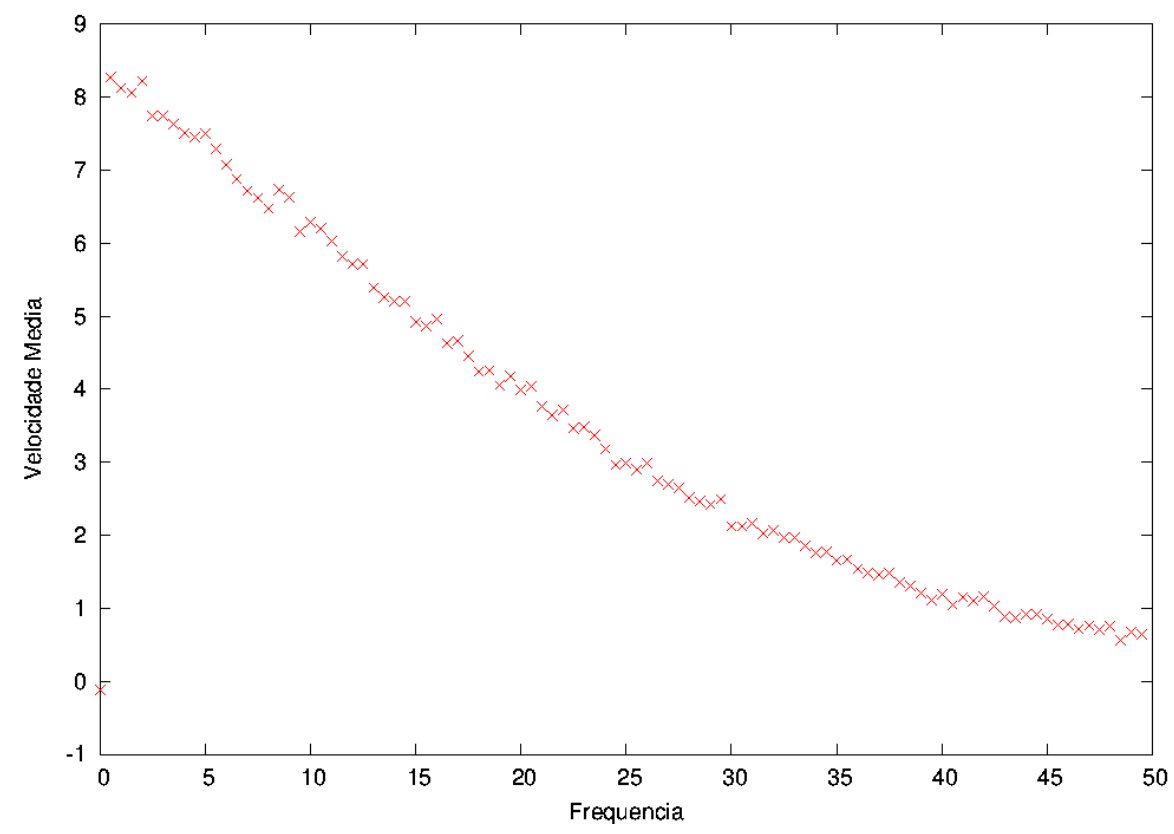

Figura 1.5: Velocidade média das partículas em função da freqüência $\gamma$ de oscilação do potencial, para uma ampla faixa de freqüência. A força externa utilizada é nula $(F=0)$ e $k_{B} T=1$. As unidades utilizadas são arbitrárias e os valores mostrados são médias de 400 simulações.

menor se estiver em temperaturas maiores.

Verificamos também como varia o fluxo em função da força externa $F$ contrária ao movimento provocado pelo potencial assimétrico, o que evidencia o trabalho mecânico realizado pelo motor. Aqui mantemos constante a freqüência $\gamma$, para a qual escolhemos o valor 1 que, de acordo com o que vimos acima, maximiza o fluxo nas condições escolhidas. Como era esperado, à medida que aumentamos a força $F$, temos uma diminuição da velocidade média (do fluxo de partículas), e uma força acima de 10 (unidades arbitrárias) inverte a direção do fluxo. Este valor da força externa para o qual temos uma inversão na direção de movimento do motor é conhecido como força de parada (stalling force) ${ }^{1}$. Este comportamento está ilustrado na Figura 1.6.

Vemos que os resultados obtidos com a simulação que realizamos estão de acordo com o que foi descrito por Astumian em seu trabalho. Isto corrobora o modelo apresentado por Astumian, uma vez que a simulação não estava restrita ao limite adiabático.

A análise dos modelos apresentados neste capítulo nos mostra que, para uma descrição do movimento induzido por flutuações, nas escalas de energia, tempo e espaço onde operam as proteínas motoras, são necessários três ingredientes: i) a anisotropia do potencial, que reflete a assimetria das estruturas moleculares do sistema e de suas interações, esta é a

\footnotetext{
${ }^{1}$ força de parada (stalling force): força contrária ao movimento, necessária e suficiente para parar o motor molecular.
} 


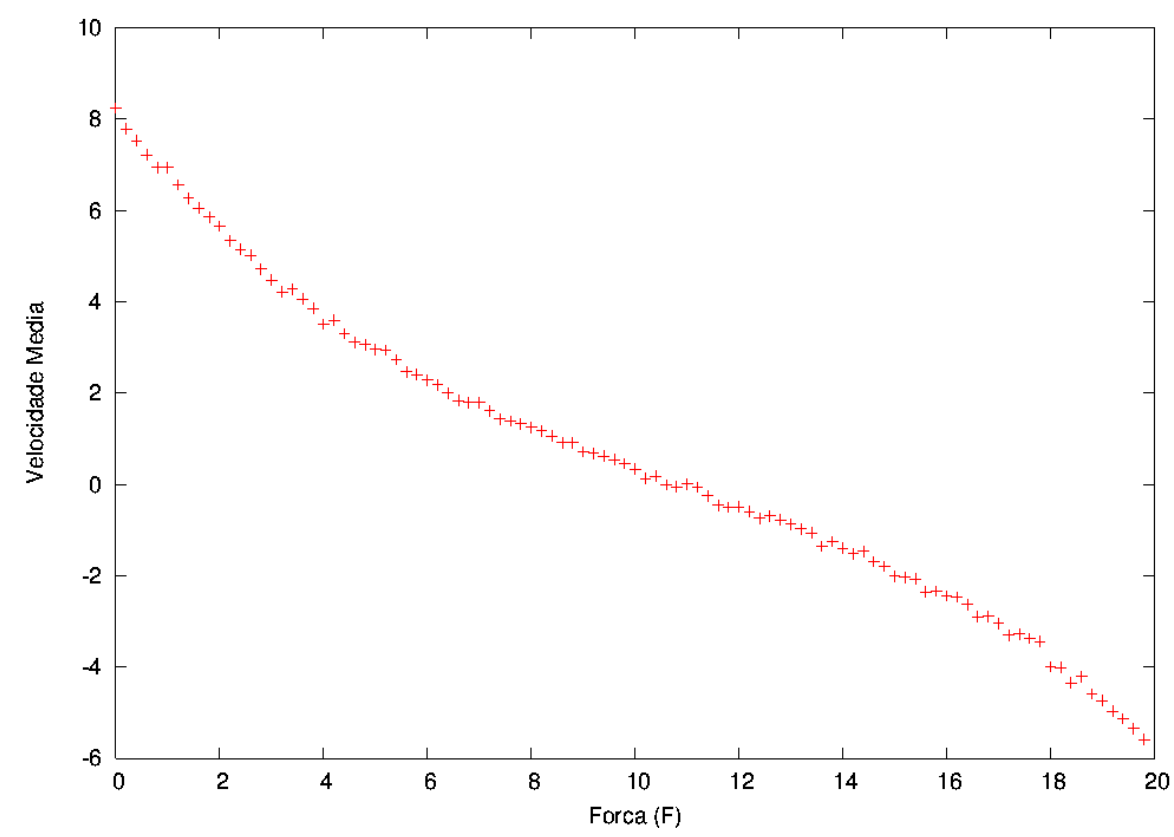

Figura 1.6: Velocidade média das partículas em função da força externa $F$ contrária ao movimento (aqui utilizamos $k_{B} T=1$ e $\gamma=1$ ). As unidades utilizadas são arbitrárias e os valores mostrados são médias de 400 simulações.

única assimetria espacial introduzida nos modelos, sendo portanto, fundamental para que tais modelos sejam capazes de resultar em um movimento assimétrico; ii) o ruído térmico, que permite que as transições entre os mínimos do potencial ocorram; iii) as flutuações atérmicas, que fornecem energia ao sistema, quebrando o balanceamento detalhado entre os estados microscópicos (o sistema deixa de ser microscópicamente reversível), o que mantém o sistema fora de equilíbrio termodinâmico (permite, portanto, que tais modelos descrevam a realização de trabalho sem violar a segunda lei da termodinâmica).

Tais modelos se mostram suficientes para explicar qualitativamente o que se observa em muitos experimentos in vitro com motores moleculares, nos quais se costuma medir diversas características do deslocamento de tais partículas proteicas, tais como a velocidade e o trabalho realizado (medindo-se, em geral por meio de pinças ópticas, a força contra a qual o movimento ocorre) [19], [46], [47]. Apesar do confronto com dados experimentais ser sempre limitado pela forma do potencial, da qual se pode inferir muito pouco além da assimetria e grosseiramente a profundidade relativa dos poços, a partir da energia liberada pela hidrólise do ATP, tais modelos são essenciais na descrição dos princípios básicos que regem o funcionamento de tais partículas.

No próximo capítulo faremos uma breve revisão de dados experimentais encontrados na literatura que nos mostram um fenômeno presente em alguns sistemas de transporte intracelular mediado por motores moleculares, que nos parece complexo demais para ser entendido apenas com modelos que descrevem a dinâmica de um motor, como o que acabamos de estudar. Este fenômeno é a bidirecionalidade observada no movimento de 
organelas (como mitocôndria, complexo de Golgi, ou o núcleo celular), vesículas lipídicas ou complexos macromoleculares (como partículas ribossomais, proteínas, RNA ou mesmo vírus). Este tipo de movimento é caracterizado por mudanças abruptas (em menos de um milissegundo [48]) no sentido em que o objeto se move no interior da célula, ou seja, apesar de apresentar movimento vetorial num dado sentido (claramente não se trata de um movimento difusivo), este sentido é freqüentemente invertido, e segue-se um movimento vetorial no sentido oposto. 


\section{Capítulo 2}

\section{Experimentos que apresentam bidirecionalidade}

A abordagem que procuramos expor no capítulo anterior, com modelos mínimos para o funcionamento dos motores moleculares, nos permite entender, através de conceitos físicos, como essas partículas motoras realizam trabalho mecânico. Esta abordagem se mostra, em grande parte, suficiente para explicar resultados experimentais obtidos in vitro em que se observa diretamente o movimento de uma única proteína motora sobre um filamento proteico [19], [46], [47], [49], [50], [51]. A observação de fenômenos de transporte intracelular em experimentos in vivo, por outro lado, se mostra bem mais complexa [16], [27].

A maioria dos trabalhos encontrados na literatura que tratam (tanto experimentalmente como teoricamente) do transporte vetorial de objetos intracelulares descrevem um movimento unidirecional, no qual o objeto parece se deslocar de modo relativamente uniforme ao longo de um filamento proteico até que este movimento pare e se torne aparentemente um movimento difusivo simples (ver, por exemplo, [52]). Este transporte unidirecional de vesículas e organelas ainda parece ser relativamente bem descrito pelo simples fato de partículas motoras se moverem unidirecionalmente sobre o filamento, arrastando, presas à sua "cauda", o objeto a ser transportado. Neste modelo, o movimento da organela corresponde ao movimento do motor molecular e os modelos do tipo apresentado no capítulo anterior seriam suficientes para descrever o este processo que seria limitado apenas pela processividade $^{1}$ dos motores presentes.

Recentemente, têm sido obtidos resultados bastante precisos sobre fenômenos de transporte intracelular, nos quais se consegue acompanhar, por exemplo, o movimento de vesículas lipídicas no interior de células por períodos de tempo suficientemente longos e com uma taxa de obtenção de imagens alta o bastante para que este movimento seja

\footnotetext{
${ }^{1}$ processividade: número médio de "passos" dados por um motor molecular, até se soltar do filamento.
} 
bem caracterizado quanto aos parâmetros biofísicos. Tais experimentos in vivo têm revelado novos fenômenos no transporte intracelular de objetos (como vesículas e organelas), fenômenos que não podem ser explicados pelo simples movimento vetorial de partículas motoras às quais estes objetos estariam presos. O restante deste trabalho está norteado para a proposta de um novo modelo teórico que explique um destes novos fenômenos de transporte observados em experimentos in vivo: o transporte bidirecional sobre microtúbulos.

A bidirecionalidade é definida como a propriedade, apresentada por alguns "objetos intracelulares" que se movem sobre microtúbulos, de reverter freqüentemente (em intervalos de poucos segundos) o sentido do seu movimento [27]. Exemplos de tais "objetos intracelulares" que apresentam este movimento bidirecional são vesículas lipídicas, organelas e mesmo alguns vírus que fazem uso dos motores moleculares que se deslocam sobre os microtúbulos para se moverem no interior da célula. Identifica-se, ao se acompanhar detalhadamente o movimento apresentado por estes objetos, um movimento razoavelmente persistente numa determinada direção ${ }^{2}$, que é abruptamente invertida (em menos de um milissegundo [48]), seguindo-se o movimento vetorial na direção oposta, e assim por diante, seguindo-se períodos de movimento intercalados por reversões. É importante notar que os movimentos que apresentam esta propriedade de bidirecionalidade são claramente distintos de um movimento difusivo simples, dado que estes "objetos" desenvolvem, entre as inversões, movimentos processivos, com alguns segundos de duração e velocidades da ordem de $1 \mu \mathrm{m} / \mathrm{s}$.

Apesar do movimento bidirecional, o saldo final é quase sempre um transporte direcionado em média, sendo construídos gradientes intracelulares dos objetos transportados. Isto é possível regulando-se o tempo e/ou a velocidade do movimento em cada sentido, de modo que a soma das distâncias percorridas num sentido seja diferente daquela no sentido oposto. Este movimento parecer ser mediado pelos mesmos motores moleculares empregados no movimento unidirecional, entretanto, o modo como se dá tal movimento ainda não está claro.

O movimento dos motores isolados tem sido bem caracterizado quanto aos parâmetros biofísicos envolvidos, através de experimentos in vitro com um único motor que se desloca sobre o filamento, manipulado por pinças ópticas. Estes motores apresentam movimentos unidirecionais que parecem ser bem explicados por modelos do tipo apresentado no capítulo anterior. Nos experimentos in vivo, por outro lado, observa-se apenas o movimento do objeto transportado (sejam eles vesículas, organelas ou macromoléculas), não sendo observados os motores moleculares individualmente — estes, algumas vezes, não

\footnotetext{
${ }^{2}$ direção e sentido: Como os termos "unidirecional" e "bidirecional" estão bem estabelecidos na literatura, como atributos de um movimento que sempre ocorre em uma única dimensão, utilizaremos em todo este trabalho a palavra "direção" com o significado atribuído normalmente (pelos físicos) à palavra "sentido", ou seja, tais palavras serão sinônimos, salvo explicação em contrário.
} 
são nem sequer identificados, apesar de serem considerados essenciais para que ocorra o movimento. É apenas o movimento intracelular do objeto transportado que se mostra, muitas vezes, bidirecional.

Até o fim da década de 1990, o movimento bidirecional havia sido observado apenas em poucos sistemas experimentais e, por isso, era visto como uma mera curiosidade. Entretanto, recentemente se observou um grande aumento no número de sistemas que apresentam tal tipo de movimento, o que chamou a atenção para este fenômeno. O fato deste movimento ter sido de certo modo negligenciado até poucos anos parece ser explicado pela grande dificuldade de se acompanhar o movimento intracelular de objetos com precisão suficiente para bem caracterizá-lo. Para que o movimento bidirecional seja observado é necessária a obtenção de imagens bastante precisas espacialmente e tiradas a uma taxa relativamente alta, caso contrário, passarão desapercebidos movimentos num dado sentido que durem poucos milisegundos ou por apenas alguns nanômetros, e um movimento bidirecional parecerá unidirecional. Apenas recentemente foram desenvolvidos aparatos experimentais que possibilitam acompanhar o movimento de estruturas intracelulares (como vesículas e organelas) por tempo suficiente para que sejam obtidas boas medidas de velocidade e distâncias percorridas, e boas estimativas da força exercida pelo motor (ou conjunto de motores) responsável pelo movimento. Isso parece explicar porque sistemas experimentais que aparentemente apresentavam movimentos unidirecionais agora têm mostrado movimentos bidirecionais [27].

Hoje o movimento bidirecional é considerado bastante relevante, sendo observado nos mais diversos contextos biológicos, como o movimento de mitocôndrias no interior de axônios [53], [54], [55], o movimento de grânulos de pigmento em melanócitos de mamíferos [56] e melanóforos de sapos e peixes [57], [58], o movimento de vesículas lipídicas em embriões de Drosophilas [31], e o movimento de vírus que fazem uso do sistema de transporte sobre microtúbulos para se deslocarem no interior das células [13], [59].

Um fenômeno tão difundindo entre as células eucariotas deve apresentar vantagens evolutivas, o que pode parecer pouco óbvio se o comparamos ao transporte unidirecional, no qual o objeto é transportado diretamente ao seu destino. Entretanto, diversas vantagens têm sido apontadas para o transporte bidirecional [16], [27]. Uma delas é a rápida alteração do sentido do movimento do objeto, tanto de acordo com eventuais mudanças nas necessidades celulares como para correção de erros aleatórios no destino escolhido para o transporte. Outra vantagem é a possibilidade de estabelecer distribuições suaves dos objetos transportados ao longo do percurso, sem necessariamente confiná-los na extremidade final do microtúbulo (o que pode ser biologicamente interessante em algumas situações). Evitar obstáculos que impediriam o movimento contínuo e uma melhor exploração do espaço intracelular também podem ser vantagens no conturbado ambiente citoplasmático. Uma vantagem da bidirecionalidade pouco discutida, mas não menos importante, é a reciclagem dos próprios motores: se eles estiverem sempre presos aos objetos 
transportados, seja qual for a direção do transporte, a concentração dos motores não ficará muito desigual entre uma extremidade e outra do microtúbulo (uma vez que objetos são constantemente transportados em ambas as direções), o que evita a questão de como estes motores fariam o cominho de volta sobre o microtúbulo, uma questão pertinente quando se discute o transporte unidirecional.

Neste capítulo discutiremos alguns aspectos biológicos e experimentais do estudo dos fenômenos de transporte intracelular, sobretudo aqueles que tangem o transporte bidirecional sobre microtúbulos. Em seguida descreveremos os resultados encontrados na literatura para um sistema experimental bem caracterizado, que apresenta transporte bidirecional. Por fim, apresentaremos os modelos teóricos propostos pelos pesquisadores experimentais desta área para interpretar os fenômenos observados.

\subsection{Transporte intracelular sobre microtúbulos: aspectos bioquímicos e parâmetros biofísicos}

Na maioria das células eucariotas (exceção feita às células musculares), o transporte sobre os filamentos de actina, mediado por motores da família das miosinas, parece ser responsável por deslcamentos menores, realizando um transpote local de objetos. O transporte por longas distâncias (vários micrômetros) parece ocorrer, na grande maioria das vezes, sobre os microtúbulos, mediado por motores das famílias das kinesinas e das dineínas - é neste tipo de transporte que se observa o movimento bidirecional de vesículas, organelas e complexos macromoleculares [27]. Os microtúbulos são polímeros filamentosos compostos de monômeros de tubulina alpha e beta ligadas de maneira "cabeça-cauda" (head-to-tail) [60]. Deste modo, os microtúbulos apresentam uma estrutura periódica polarizada (assimétrica), com extremidades distintas química e morfologicamente. Estas extremidades são chamadas de "extremidade-mais" e "extremidade-menos", e em células eucarióticas típicas os microtúbulos ficam normalmente dispostos com a extremidade-mais voltada para o córtex (periferia) celular, enquanto as extremidades-menos de vários microtúbulos organizam-se em torno de estruturas chamadas microtubules organizing centers localizadas próximas do núcleo celular [27]. As proteínas motoras que realizam transporte de objetos sobre microtúbulos pertencem essencialmente a duas superfamílias, as kinesinas e as dineínas. Estes motores reconhecem a polaridade dos microtúbulos (conforme vimos nos modelos do capítulo anterior), de modo que os motores da superfamília das kinesinas se movem exclusivamente em direção à extremidade-mais, enquanto quase todos os motores descritos pertencentes à superfamília das dineínas se movem em direção à extremidade-menos dos microtúbulos [2] (ao menos em experimentos onde se consegue acompanhar diretamente o movimento da proteína motora). A Figura 2.1 ilustra este cenário intracelular. 


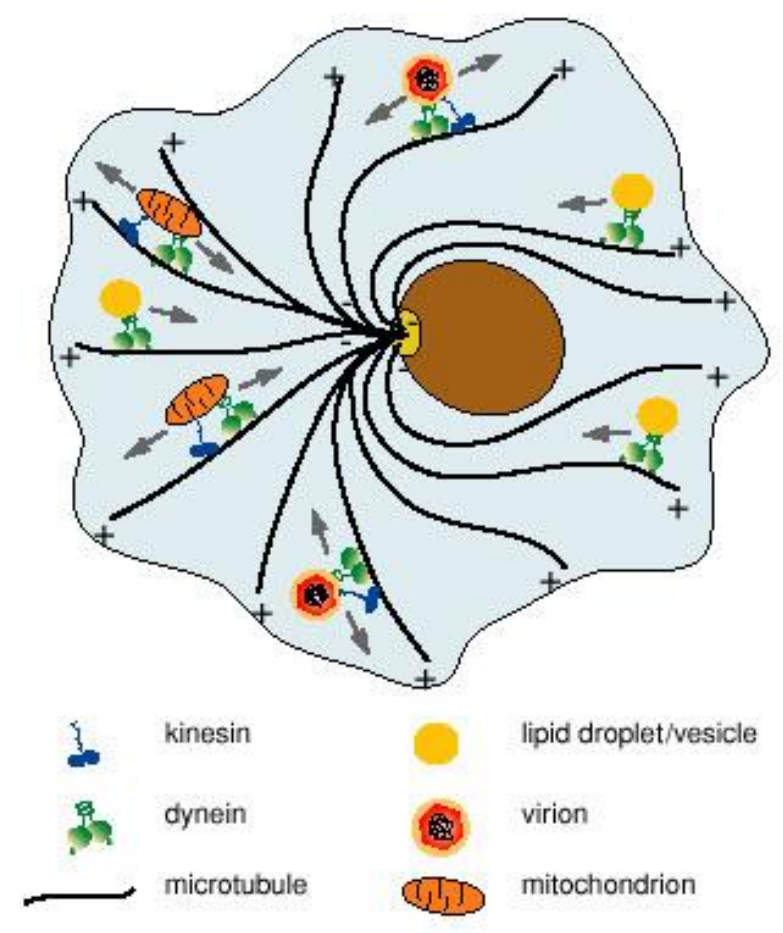

Figura 2.1: Diagrama de uma célula, mostrando a organização radial dos microtúbulos e alguns objetos intracelulares que se movem bidirecionalmente, fazendo uso de proteínas motoras multiméricas. Fonte: Gross (2004) [27].

A maioria destas proteínas motoras possuem estruturas multiméricas (com pelo menos duas cadeias polipeptídicas), com dois domínios motores ligados através de um domínio filamentar a uma "cauda" globular [2]. Os domínios motores interagem com o microtúbulo e possuem atividade ATPásica, sendo responsáveis pela realização de trabalho mecânico (ver Capítulo 1). O fato destes motores aparentemente necessitarem estar na forma dimérica, com duas unidades motoras, parece ser essencial para que eles não percam o contato com o microtúbulo a cada passo, realizando o movimento de forma processiva. A cauda globular liga o motor ao objeto transportado, o que parece acontecer através de receptores que ainda não estão muito bem caracterizados molecularmente.

Estas proteínas motoras, que estão muito bem caracterizadas como as responsáveis pelos fenômenos de transporte unidirecional, parecem ser as responsáveis por todo tipo de transporte vetorial realizado nas células, incluindo os movimentos bidirecionais [2], [16], [61]. Entretanto, apesar de aparentemente fazer uso dos mesmos motores, o transporte bidirecional não pode ser entendido como uma mera extensão do transporte unidirecional. Um ponto de extrema importância tanto biológica quanto teórica, que parece ressaltar as diferenças entre estes dois modos de transporte, é a forma como eles devem ser regulados.

No transporte unidirecional apenas um tipo de motor está ligado à superfície do objeto transportado, e a hidrólise do ATP nas unidades motoras gera a força necessária para o movimento da proteína como um todo (conforme vimos no capítulo anterior), que arrasta 
consigo o objeto. A regulação deste tipo de transporte pode se dar aparentemente de duas maneiras, através do controle da ligação da proteína motora ao objeto (que pode mudar tanto a velocidade média, através da fração de tempo que o motor passa ligado ao objeto, como a direção do movimento, alterando o tipo de motor empregado) e regulando a atividade catalítica da unidade motora empregada (que, mudando a potência do motor, mudaria a velocidade instantânea do movimento).

No transporte bidirecional têm-se verificado que pelo menos duas espécies diferentes de motores estão ligadas ao mesmo tempo ao objeto transportado, cada uma com direcionalidade para um dos sentidos do microtúbulo [61]. Neste caso, a ligação do objeto ao motor não pode mais ser um ponto de controle do transporte. Acredita-se que regulação do movimento neste tipo de transporte envolva a sintonia precisa da atividade de cada espécie de motor, de modo a controlar a distância percorrida em cada direção, ou seja, parece ser importante a atividade relativa entre as duas espécies de motores presentes. No entanto, não está claro como atuam estes motores que se encontram na superfície do objeto transportado e, vale dizer, parecem estar presentes vários motores de cada espécie [2], [31]. Recentemente algumas proteínas que parecem estar envolvidas neste complexo que deve coordenar as atividades dos vários motores foram identificadas, como a dinactina, que se liga tanto à kinesina II quanto à dineína citoplasmática [62], através de um mesmo sítio, e parece aumentar a processividade ${ }^{3}$ destes dois motores [63], [64].

A parametrização precisa do movimento dos objetos intracelulares se mostra essencial para a compreensão de como esta regulação deve ocorrer. Por exemplo, a análise estatística de um grande número de corridas ${ }^{4}$ pode indicar se o processo responsável pelo término das corridas deve ser o mesmo que determina o fim do movimento processivo de um único motor ou se outros mecanismos devem estar presentes. Em experimentos in vitro, em que se observa o movimento de motores isolados sobre o microtúbulo, o fim do movimento ocorre essencialmente pelo fato do motor ter uma probabilidade constante a cada passo de perder o contato com o filamento (esta probabilidade determina diretamente a processividade do motor [65]).

Se ocorrer algo semelhante in vivo, o fim da corrida deve ser seguido de um movimento difusivo do objeto transportado, e tal evento deve ocorrer com probabilidade constante a cada instante, levando a uma distribuição exponencial decrescente para as distâncias percorridas. A regulação do movimento poderia consistir, neste caso, no controle do número de motores de cada tipo que estariam ativos simultaneamente, uma vez que quanto maior o número de motores ativos, menor a probabilidade do obejto se soltar do microtúbulo (a

\footnotetext{
${ }^{3}$ processividade: Este conceito, que definimos a pouco para o movimento de um único motor, pode ser extendido ao movimento do objeto intracelular, sem que seja precisado o movimento de motores individuais, significando, então, o tamanho médio das corridas.

${ }^{4}$ corrida (run): movimento ininterrupto do objeto observado numa dada direção, delimitado seja por períodos de parada, períodos de difusão ou pelo início imediato de um movimento no sentido contrário.
} 
processividade do movimento do objeto deve aumentar com o número de motores ativos de cada tipo). Este parece ser, de fato, o caso nos movimentos unidirecionais de estruturas intracelulares (ver [52]), mas, como veremos adiante, isto não parece ocorrer nos movimentos bidirecionais.

Por outro lado, pode-se imaginar que a processividade não seja limitante e outro mecanismo seja o principal responsável pelo fim de cada corrida. Se tal mecanismo agir, por exemplo, inativando os motores após um número fixo de passos, teríamos uma distribuição de distâncias percorridas bastante estreita em torno de um único valor. A regulação do movimento ficaria, então, a cargo deste regulador do número de passos.

Outra grandeza importante na caracterização do movimento é a força de parada (stalling force $)^{5}$. Esta grandeza é de medida relativamente fácil nos experimentos in vitro com motores isolados, entretanto, aferi-la em experimentos in vivo se mostra algo muito mais complexo. A força de parada medida para o movimento de um objeto intracelular é a principal maneira utilizada para se inferir, o número de motores que devem estar ativos simultaneamente (ver, por exemplo, [66]). Isso é feito comparando-se os valores de força observados em exprimentos in vivo e aqueles medidos in vitro com o motor isolado para isso é necessário que se determine previamente qual o tipo de motor empregado no movimento intracelular observado.

A seguir descreveremos resultados da literatura obtidos para um dos sistemas experimentais mais bem caracteriados quanto a estes parâmetros biofísicos, o transporte de vesículas lípidicas (lipid droplets) em embriões de Drosophilas [29], [31], [67].

\subsection{Transporte de Vesículas Lipídicas: um modelo experimental bem caracterizado}

Drosophilas melanogaster tornaram-se um modelo animal muito estudado tanto geneticamente (desde o início do século XX) como quanto ao desenvolvimento embrionário, e, pelo menos desde a década de 80, observa-se o movimento bidirecional de vesículas em embriões desta espécie [68]. Em 1998, Welte et al. [31] estabeleceram este sistema como modelo experimental para o estudo detalhado do movimento intracelular de vesículas lipídicas (lipid droplets). Este grupo tem realizado estudos sistemáticos com este modelo [29], [67], que se tornou um dos mais bem caracterizados quanto aos parâmetros biofísicos do movimento bidirecional. Este sistema mostra-se bastante interessante neste aspecto por se tratar de vesículas relativamente grandes, com cerca de 0,5 $\mu \mathrm{m}$ de diâmetro, o que permite o acompanhamento de seu movimento com resolução nanometrica por video-

\footnotetext{
${ }^{5}$ força de parada (stalling force): Este conceito, definido no Capítulo 1, também pode ser aplicado ao movimento do objeto intracelular.
} 
enhanced differential contrast interference (VE-DIC) microscopy acoplada a uma análise controlada por computador. Essas vesículas, por serem altamente refratárias, são excelentes para manipulação por pinças ópticas, o que permite tanto medidas diretas das forças exercidas no movimento em experimentos ex vivo, em que as células são rompidas, como medidas indiretas in vivo, em que se manipula opticamente as vesículas sem que a célula seja rompida.

Esse sistema apresenta, ainda, a vantagem da fácil manipulação genética que permite o estudo do transporte em embriões que sofreram mutações em uma proteína específica envolvida neste processo. Isto permite que se obtenha uma boa idéia da importância relativa de determinada proteína em etapas específicas do transporte.Além disso, ao longo de seu desenvolvimento, os embriões passam por três fases bastante distintas quanto ao movimento destas vesículas.

- fase 1 (balstoderme sincicial): No início do estágio de blastoderme, as vesículas se mostram espalhadas na periferia da célula.

- fase 2 (do fim do ciclo 14 ao início da celularização): Ao entrar no ciclo 14 de divisão nuclear, as vesículas saem da periferia, de modo que, ao entrar na celularização, as vesículas se mostram acumuladas numa região central do embrião. Este movimento global observado leva a um deslocamento médio durante a fase 2 de amplitude de aproximadamente $10 \mu \mathrm{m}$.

- fase 3 (gastrulação): Este acúmulo basal é revertido durante a gastrulação, com o movimento das vesículas novamente em direção a região apical das células.

Em todas essas fases o movimento apresentado é bidirecional. O que as distingue é o deslocamento médio, que na fase 1 é praticamente nulo, na fase 2 é em direção à extremidade-mais do microtúbulo e na fase 3 é em direção à extremidade-menos. Esta mudança da distribuição das vesículas ao longo das fases de desenvolvimento torna este um excelente sistema para o estudo da regulação do movimento bidirecional.

Diversos estudos deste sistema mostram fortes evidências de que, de fato, o transporte bidirecional de vesículas lipídicas ocorre sobre microtúbulos. Nos embriões de Drosophilas, os microtúbulos se localizam, durante as três fases em que se observa o movimento bidirecional, em uma posição coincidente com a região em que se observa o movimento das vesículas lipídicas [31], [68]. Além disso, este movimento é inibido tanto por drogas que causam a desestruturação dos microtúbulos como em fases do desenvolvimento embrionário em que isso ocorre naturalmente [68], [69]. Estes microtúbulos se apresentam de modo atípico, com a extremidade-menos voltada para a periferia, enquanto a extremidade-mais fica voltada para a região basal[31].

Medidas da força de parada para o movimento das vesículas nas três fases do desenvolvi- 
mento do embrião foram realizadas de modo indireto através da fração de vesículas que escapava da armadilha óptica para cada potência aplicada no laser [31]. Observou-se que, em todas as fases, a força era a mesma para os movimentos na direção apical e basal. Entretanto, o valor desta força média variou entre as fases: na fase 1 a força média observada foi $3.3 \mathrm{pN}$; na fase 2 foi de $5.5 \mathrm{pN}$; na fase 3 foi de $4.7 \mathrm{pN}$. Os autores argumentam que esta variação parece ocorrer em múltiplos de $1.1 \mathrm{pN}$. Segundo eles, isto sugere que esta variação nas forças medidas indica uma variação de um motor ativo entre as fases do desenvolvimento. Deste modo, na fase 1 teríamos 3 motores ativos para cada direção; na fase 2 teriámos 5 motores ativos em cada direção; na fase 3 teríamos 4 motores ativos em cada direção.

Em 2000, este mesmo grupo publicou um outro estudo [29] em que são mostradas fortes evidências de que a proteína motora responsável pelo movimento no sentido da extremidade-menos é, de fato, a dineína citoplasmática. Primeiramente foi mostrada uma forte correlação da dineína (através de imuno-localização) com as vesículas lipídicas após a ruptura dos embriões. Então, construiu-se geneticamente uma dineína mutante (Dhc64C), que ainda viabiliza o embrião. Estes embriões que continham a mutação continuavam apresentando o acúmulo das vesículas na fase 2 , de modo aparentemente similar ao embrião selvagem, entretanto, nos mutantes as vesículas não eram re-distribuídas na periferia durante a gastrulação. Esta observação do comportamento global das vesículas já indica uma piora no movimento na direção da extremidade-menos causada pela mutação. Uma análise mais detalhada mostrou que, de fato, este movimento está prejudicado e que a mutação causa ainda outras mudanças mais sutis já nas fases 1 e 2 do desenvolvimento, confirmando que a dineína deve ser o motor responsável pelo movimento em direção à extremidade-menos do microtúbulo.

Esta caracterização da dineína como o motor responsável pelo movimento em direção à extremidade-menos do microtúbulo permitiu que fosse feito um estudo detalhado do movimento gerado por esta proteína em sua forma selvagem no meio intracelular, através da análise estatística de um grande número de observações deste movimento. Este estudo foi feito com a análise de imagens obtidas a uma taxa de $30 \mathrm{~Hz}$, com resolução espacial da ordem de $8 \mathrm{~nm}$, voltado sobretudo para estudo do movimento na direção menos durante a fase 2 do desenvolvimento embrionário, na qual o movimento persiste por mais tempo $[29]$.

Os autores realizaram uma análise das pausas que se seguiam eventualmente às corridas, buscando esclarecer quão importantes tais pausas devem ser na regulação deste movimento. As pausas foram definidas operacionalmente como períodos em que a vesícula ficava parada (com velocidade menor que $50 \mathrm{~nm} / \mathrm{s}$ ) por pelo menos $0,23 \mathrm{~s}$. Isto pareceu caracterizar um estado bem definido, uma vez que nestes períodos o deslocamento seguia uma gaussiana de média zero, e as velocidades eram em média menores que $14 \mathrm{~nm} / \mathrm{s}$ (muito inferiores aquelas de pelo menos $150 \mathrm{~nm} / \mathrm{s}$, observadas durante os movimentos mais 
lentos). As pausas que ocorreram após o movimento na direção menos (pausa-menos), ocorreram em média a cada $5 s$ de corrida ininterrupta e duravam aproximadamente $0.6 s$, de modo que as vesículas passavam cerca de $9 \%$ do seu tempo em pausas (valores semelhantes aqueles observados para as pausas-mais). Observou-se que a duração das pausas segue uma distribuição exponencial decrescente (da forma $y(t)=A \exp \left(-t / t_{0}\right)$ ), o que sugere que a probabilidade de sair da pausa é constante no tempo. Um dado interessante é a observação de que a reversão no sentido do movimento e as pausas ocorrem de modo independente. Apenas cerca de $13 \%$ das reversões estão associadas a pausas, valor semelhante tanto para as reversões do sentido mais para o menos como do menos para o mais. Os mutantes Dhc64C por sua vez, apresentam pausas com duração média de $0.76 \mathrm{~s}$ e um intervalo entre as pausas de 2,68 s., de modo que eles passam uma porcentagem de tempo consideravelmente maior que os selvagens em pausa, $22 \%$. Como era de se esperar, dado que a freqüência das pausas está aumentada, estes mutantes tem $18 \%$ das reversões envolvendo pausas [29].

Nesse trabalho, para um deslocamento ser considerado como uma corrida ele tinha que persistir por pelo menos $30 \mathrm{~nm}$ e durar pelo menos $0.16 \mathrm{~s}$, o que evitava efeitos de artefatos devido à precisão na obtenção das imagens. As corridas, em direção à extremidade-menos, variaram muito de tamanho, sendo observadas corridas de 30 a $4000 \mathrm{~nm}$, com velocidades médias de 150 a $2000 \mathrm{~nm} / \mathrm{s}$. A maioria destas corridas não terminava por períodos de pausa, mas por uma reversão, seguindo-se uma corrida em direção à extremidademais. A distribuição que melhor aproximou as distâncias medidas para estas corridas, tanto para aquelas em direção à extremidade-menos como para aquelas em direção à extremidade-mais, em qualquer uma das fases do desenvolvimento embrionário, foi sempre a soma de duas exponenciais decrescentes (ou seja, $y(D)=A_{S} \exp \left(-D / D_{S}\right)+$ $\left.A_{L} \exp \left(-D / D_{L}\right)\right)$, com as constantes que as parametrizam variando de caso para caso $\left(D_{S}\right.$ e $D_{L}$ são as distâncias médias percorridas, respectivamente, nos movimentos curto (short) e longo (long), as contantes multiplicativas, $A_{S}$ e $A_{L}$ apenas ajustam as exponenciais de acordo com as freqüências observadas para cada tipo de movimento). Tentativas de parametrizar os dados, para qualquer um dos casos, por uma única exponencial decrescente se mostraram estatisticamente ruins ( $\operatorname{com} \chi^{2} \geq 3$ ). Este fato sugere, segundo os autores, que tais movimentos são compostos de dois processos distintos, um movimento curto e um longo que estariam associados a estados diferentes da vesícula. Para o movimento em direção à extremidade-menos na fase 2 , os parâmetros $D_{S}=98 \mathrm{~nm}$ e $D_{L}=1.068 \mathrm{~nm}$ (que caracterizam as distâncias médias percorrida no movimento curto e longo respctivamente). De acordo com os autores, esta distinção de dois tipos diferentes de movimento, em cada direção, seria ainda corroborada pelo fato de tais movimentos, quando analisados separadamente, mostrarem velocidades bem distintas: no caso do movimento em direção à extremidade-menos na fase 2 , a velocidade do movimento curto é de cerca de $200 \mathrm{~nm} / \mathrm{s}$, enquanto para o movimento longo é de $430 \mathrm{~nm} / \mathrm{s}$. Estes movimentos passaram a ser chamados então de corridas "longas-rápidas" e corridas "curtas-lentas". 
Para o controle do deslocamento global, passa a ser importante a razão $\left(R_{S L}\right)$ em que ocorrem estes tipos de movimento. Se o movimento em direção à extremidade-menos ocorre predominantemente do modo "longo-rápido", mesmo que ele seja menos freqüentemente observado (por ocupar uma fração menor do tempo), ele pode prevalecer sobre um movimento em direção à extremidade-mais em que ocorre predominantemente o movimento do tipo "curto-lento". Calculou-se, então, a razão $R_{S L}$ que nos dá esta medida para cada fase do desenvolvimento e cada direção de movimento. Observou-se que a grande diferença no comportamento das vesículas entre as fases 2 e 3 se dá quanto ao movimento em direção à extremidade-mais que, entre estas fases, mostra uma redução na constante $D_{L}$ de $1.144 \mathrm{~nm}$ para $780 \mathrm{~nm}$ e uma aumento da razão $R_{S L}$ de 1, 05 para 2,22. Estes dois fatos contribuem para uma redução de $842 \mathrm{~nm}$ para $415 \mathrm{~nm}$ na distância média total das corridas (incluindo os dois tipos de movimento) em direção a esta extremidade, que explica a mudança na direção do deslocamento médio observada entre as fases 2 e 3 . O movimento em direção à extremidade-menos praticamente não sofre alterações entre estas fases do desenvolvimento [29].

O movimento com a proteína mutante Dhc64C também se mostrou melhor parametrizado pela soma de duas exponenciais decrescentes, entretanto, neste caso as distâncias médias percorridas em cada tipo de corrida foram bem menores que para a proteína selvagem (sem mutação), com $D_{S}=44 \mathrm{~nm}$ e $D_{L}=209 \mathrm{~nm}$.

O fato das paradas parecerem ser sempre fenômenos independentes das reversões e acontecerem menos freqüentemente que estas foi interpretado pelos autores como indicativo de que os movimentos bidirecionais observados, em geral, não são limitados pela processividade dos motores. Outras evidências corroboram esta hipótese. Uma delas é o fato das distâncias observadas não variarem de acordo com o número de motores, estimados pelas medidas de força de parada. Como a processividade aumenta com o número de motores ativos, era de se esperar que, caso a processividade limitasse o movimento, as distâncias percorridas para as corridas da fase 2 fossem maiores que aquelas para as corridas da fase 3, o que não se observa. Outra evidência é o fato das distâncias observadas, mesmo para os movimentos do tipo "longo-rápido", serem menores do que aquelas esperadas de acordo com a processividade estimada para o número de motores que imagina-se estar presente (para um número de 5 dineínas espera-se uma processividade da ordem de $1.800 \mathrm{~nm}$, consideravelmente maior que os $1.070 \mathrm{~nm}$ observados para os movimentos do tipo "longo-rápido" do movimento em direção à extremidade-menos, tanto na fase 2 como na 3). Entretanto, como não se identificou o motor responsável pelo movimento em direção à extremidade-mais, nada se pode dizer quanto ao que seria a processividade esperada neste sentido.

O fato do tipo de movimento "longo-rápido" ser bem parametrizado por uma única exponencial decrescente sugere que o mecanismo de parada deste tipo de corrida tenha uma probabilidade constante de ocorrer, não dependendo do número de passos dados, 
por exemplo. Como normalmente as corridas não são seguidas de períodos de parada, os autores sugerem que o que determina o fim de uma corrida é, em geral, o início de uma corrida contrária, e, para isso, deve existir algum tipo de proteína que coordene as atividades dos motores que atuam em direções contrárias. Esta proteína controladora estaria sujeita a mudanças impostas pela célula, que controlaria assim as fases do desenvolvimento.

Os autores associam ainda os movimento do tipo "curto-lento" a uma competição entre motores que promovem o movimento num sentido e aqueles que promovem o movimento no sentido oposto. Isto explicaria porque este tipo de movimento é não apenas mais curto como também mais lento. A seguir, discutiremos alguns modelos propostos na literatura para entender estes fenômenos de bidirecionalidade.

\subsection{Modelos teóricos encontrados na literatura para explicar o transporte bidirecional}

Apesar do movimento bidirecional ser bastante variado de acordo com o sistema biológico observado (muitas vezes, até mesmo os tipos de proteínas motoras empregados nas diferentes células são diferentes), procura-se desenvolver modelos teóricos que permitam uma compreensão geral deste fenômeno. Três hipóteses foram levantadas para explicar como os motores responsáveis pelo movimento bidirecional devem ser coordenados [16], [27]. Em todas elas se assume que motores de diferentes tipos são responsáveis pelo movimento em cada direção (o que permite que a geração de força seja explicada por modelos do tipo visto no Capítulo 1) e todas elas permitem que um ou mais motores de cada tipo sejam empregados simultaneamente.

Na primeira delas assume-se que apenas um tipo de motor estaria ligada ao objeto transportado a cada instante e o movimento bidirecional seria entendido como uma simples composição de movimentos unidirecionais independentes. Mudanças na direção do movimento seriam, neste caso, atribuídas a uma mudança no tipo de motor empregado, que possivelmente competiriam pelo mesmo sítio de ligação na superfície do objeto. Este não parece ser o caso, ao menos não na maioria dos sistemas estudados em detalhe. Aparentemente, nos sistemas que apresentam movimento bidirecional em que se conseguiu caracterizar ao menos um dos motores empregados, este motor parece permanecer ligado ao objeto mesmo durante o movimento na direção oposta àquela em que ele atua. É isto que parece estar acontecendo no experimento realizado por Ma et al. [70], por exemplo, no qual foram construídos mutantes fluorescentes de dineína citoplasmática que se movem em ambas as direções sobre microtúbulos, não apenas em direção à extremidade-menos, como se esperaria para as dineínas. Outra evidência de que este mecanismo não parece ser o empregado é o fato do transporte bidirecional ter sido reconstituído in vitro a partir de organelas purificadas, sem a adição de novos motores, indicando que ambos devem se 
encontrar presos à organela ao menos durante a purificação desta [30], [71]. Isto também parece acontecer in vivo, uma vez que a quantidade de motores ligados às mitocôndrias ou grânulos de pigmento não parece mudar mesmo quando varia o tempo relativo de transporte na direção mais ou menos [54], [57]. Uma última evidência de que este mecanismo não deve ocorrer durante o transporte bidirecional é o fato de mutações em um dos tipos de motores empregados prejudicar o transporte em ambas as direções, conforme descrito por Gross et al. [67] num experimento em que mutações na dineína (que se move normalmente em direção ao terminal menos) afetam o movimento na direção mais, no transporte de vesículas lipídicas em embriões de Drosophila.

A segunda possibilidade é os dois tipos de motores estarem presentes tanto no movimento numa direção quanto no movimento na direção oposta. Estando ambos os motores presentes, vislumbra-se duas novas alternativas de coordenação. Estes dois tipos de motores podem estar ativos durante todo o transporte, realizando uma espécie de "cabo-de-guerra" em que ora uma direção predomina, ora a outra predomina, dependendo essencialmente do número de motores ativos de cada tipo num determinado instante. Este também não parece ser o método empregado, ao menos não para o transporte de vesículas lipídicas que analisamos na seção anterior. Vimos que no transporte bidirecional de vesículas lipídicas é possível a alteração do movimento apenas numa das direções (na fase 3 observa-se uma redução do comprimento médio das corridas em direção à extremidade-mais, sem alteração do movimento em direção à extremidade-menos), o que contradiz a idéia de "cabo-de-guerra", em que a melhora do movimento numa direção deve ser acompanhada pela piora no movimento contrário. Além disso, se de fato ocorresse um "cabo-de-guerra", mutações que piorassem a eficácia de um tipo de motor automaticamente deveriam se refletir em um aumento da velocidade e da força resultante no movimento realizado na direção oposta. Entretanto, o que foi observado no transporte de vesículas lipídicas em embriões de Drosophila foi uma diminuição da força medida para o movimento em ambas as direções quando a dineína (aparentemente responsável apenas pelo transporte na direção menos) é mutada [67]. Outras evidências experimentais têm surgido na literatura indicando que tratamentos que visam abolir o movimento de organelas em uma direção acabam prejudicando o movimento em ambas as direções [62], [72], [73].

Alternativamente, supõem-se que as duas espécies de motores presentes poderiam atuar de maneira alternada, ou seja, enquanto uma delas estaria ativa, a outra estaria inativa, de modo que o movimento ocorreria sem restrições nas duas direções. Neste caso, a coordenação da atividade destes dois tipos motores seria realizada por elementos ainda não identificados que devem interagir com ambos os motores simultaneamente. Devido as evidências contra os modelos alternativos apresentados acima, este modelo tem sido aceito por exclusão [16], [27]. Este modelo de coordenação dos motores supõem que existam mecanismos controladores que, por exemplo, percebam a atividade de um tipo de motor para, em função dela, inativar o outro tipo. Se tal mecanismo existir, trata-se provavelmente de um complexo proteico que interage com os motores de ambos os tipos 
presentes na superfície do objeto transportado. Este complexo ainda não foi identificado, possivelmente por não ser estável fora do meio intracelular ou onde não esteja em contato com a membrana da organela ou vesícula transportada. Se este complexo hipotético de fato existir, sua caracterização passa a ser de suma importância, uma vez que seria ele o grande responsável pela regulação das propriedades do transporte e não os motores.

Algumas evidências que corroboram este modelo são:

- Ambos os tipos de motores parecem estar presentes simultaneamente nos objetos transportados bidirecionalmente;

- Tem sido observado que é possível alterar o movimento numa direção sem modificar o movimento na direção contrária [31];

- Neste modelo, as forças de parada nas direções contrárias não precisam ser diferentes. Vimos que vesículas lipídicas apresentam, de fato, forças de parada iguais para ambas as direções [29];

- Neste caso, defeitos num tipo de motor não devem melhorar o movimento na direção contrária. Pelo contrário, o movimento contrário pode piorar se a coordenação entre os motores for prejudicada. Isto também foi observado em experimentos com vesículas lipídicas [67], no qual mutações na dineína prejudicaram o movimento em ambas as direções.

Vários experimentos têm mostrado evidências de que vários motores (entre 1 e 7) de cada tipo podem ser empregados simultaneamente [19], [27], [31]. Este número parece variar entre diferentes sistemas experimentais ou mesmo entre as fases do desenvolvimento embrionário no caso dos embriões de Drosophilas. O que estas variações representam ainda não está claro [19], [27]. Nenhum dos modelos acima considera este fato, que parece trazer dificuldades a possíveis mecanismos controladores da atividade dos motores.

Além da atividade relativa entre os diferentes tipos de motores empregados, outro meio de interferir no direcionamento médio do transporte bidirecional é pelas taxas com que os objetos iniciam ou terminam o processo, o que costuma acontecer nas extremidades do microtúbulo. Se os objetos transportados são removidos por algum processo ao atingir uma das extremidades, esta extremidade passa a atuar como um "ralo" para o transporte, e o transporte bidirecional iria fornecer constantemente novos objetos para este ralo. Este mecanismo regulatório parece estar presente em ao menos um caso, no transporte de grânulos de pigmento em melanócitos de mamíferos, em que os grânulos se movem bidirecionalmente em microtúbulos, mas, ao atingir o córtex celular, são seqüestrados pela miosina $\mathrm{V}$ que realiza então um transporte unidirecional sobre os filamentos de actina espalhados aleatóriamente nesta região [16]. 
Revimos neste capítulo alguns resultados experimentais que mostram movimento bidirecional de objetos intracelulares, como este movimento costuma ser parametrizado e quais os modelos teóricos levantados para interpretar estes resultados. No próximo capítulo apresentaremos uma abordagem utilizada para estudar fenômenos que envolvam o transporte de partículas interagentes em redes unidimensionais. Estes modelos recentemente vêm sendo utilizados no estudo do transporte intracelular realizado por motores moleculares, sobretudo para o transporte unidirecional [32], [33]. Nós, entretanto, faremos apenas uma descrição de alguns resultados destes modelos que nos serão úteis no quarto capítulo, no qual propomos um novo modelo para entender os fenômenos de transporte bidirecional que acabamos de descrever. 


\section{Capítulo 3}

\section{Sistemas difusivos dirigidos: modelos do tipo ASEP e TASEP}

Vimos no capítulo anterior que, apesar dos motores moleculares apresentarem movimento unidirecional, no meio intracelular surgem fenômenos mais complexos, como o transporte bidirecional de objetos como vesículas lipídicas, organelas (como a mitocôndria e o núcleo) e complexos macromoleculares (como partículas ribossomais e alguns vírus). Vimos também os principais modelos propostos na literatura para explicar o movimento bidirecional e as evidências experimentais que corroboram ou refutam tais modelos. Entretanto, nos parece que, apesar dessas explicações serem plausíveis, outros fenômenos podem surgir neste meio intracelular, fenômenos que podem apresentar conseqüências no movimento do objeto transportado e eventualmente fornecerem uma explicação para o movimento bidirecional.

Diversos autores têm procurado desenvolver modelos mais complexos e, em geral, mais realistas, para o transporte realizado pelos motores moleculares [33], [74], [75], [76], [77]. É fácil imaginar, por exemplo, que vários motores de um dado tipo, movendo-se simultaneamente sobre um mesmo filamento, sejam capazes de produzir efeitos não-triviais, decorrentes das possíveis interações entre eles. O principal aspecto que se tenta introduzir nesses modelos é, portanto, algum tipo de interação entre as partículas que se movem sobre um mesmo filamento.

De fato, recentemente se observou num experimento in vitro, em que se acompanhou o comportamento kinesinas fluorescentes se movendo sobre um microtúbulo, que tais fenômenos realmente ocorrem [32]. Neste experimento observou-se que regiões com alta densidade de motores podem co-existir com regiões mais rarefeitas. Neste capítulo estudaremos modelos matemáticos que consideram a interação mais simples possível entre as partículas que se movem, uma interação do tipo volume excluído, e explicam como surgem fenômenos do tipo descrito neste trabalho de Nishinari et al. (2005). Este tipo 
de interação permite se verifique facilmente, por meio de simulações numéricas, que mudanças podem surgir no fluxo de partículas devido às interações entre elas. Além disso, os modelos mais simples permitem soluções analíticas no estado estacionário e algumas aproximações permitem que tais soluções sejam obtidas mesmo para estados transientes. Estamos interessados principalmente nestas soluções para os estados transientes.

Estudamos em particular os modelos unidimensionais do tipo ASEP (asymetric simple exclusion model) e TASEP (totaly asymetric simple exclusion model). Estes modelos foram originalmente desenvolvidos para entender o limite hidrodinâmico (macroscópico) que descreve o escoamento de fluidos a partir de modelos microscópicos, num contexto chamado de "sitemas difusivos dirigidos" (driven difusive systems) [34], [74], [78]. Estes sistemas caracterizam-se por apresentar taxas de transição que não satisfazem balanço detalhado (mas conservam o número de partículas) e, conseqüentemente, os estados estacionários não podem ser representados por medidas de Gibbs [38], [79]. Deste modo, tais sistemas estão a priori fora de equilíbrio termodinâmico.

Em geral, considera-se o transporte de partículas em redes unidimensionais. No ASEP, as partículas saltam estocasticamente de um sítio da rede para o sítio vizinho, com probabilidades diferentes para os sítios à direita e à esquerda (ou seja, um passeio aleatório assimétrico), e interagem entre si por meio de volume excluído. Se associarmos para cada sítio uma variável que assume os valores 0 ou 1, de acordo com o estado de ocupação deste sítio (0 se o sítio está vazio e 1 se este sítio está ocupado por uma patícula), o sistema irá evoluir de modo que, a cada instante de tempo $d t$, os seguintes eventos podem ocorrer para dois sítios vizinhos na rede:

$$
\begin{aligned}
(0)_{i}(1)_{i+1} & \rightarrow(1)_{i}(0)_{i+1} \text { com probalidade } q d t \\
(1)_{i}(0)_{i+1} & \rightarrow(0)_{i}(1)_{i+1} \text { com probalidade } p d t
\end{aligned}
$$

Esta dinâmica estocástica vale para quaisquer dois sítios consecutivos da rede se esta for periódica (anel) ou, como no caso em que estamos interessados, se for considerada uma rede infinita. Caso seja considerada uma rede finita, deve-se estabelecer também a dinâmica que rege as fronteiras deste sitema. A única diferença entre o ASEP e o TASEP é que, neste último, as partículas têm probabildade nula de saltar para um dos lados, só podendo andar para frente ou ficar parada - ou seja, a assimetria no movimento é total (ver Figura 3.1). 


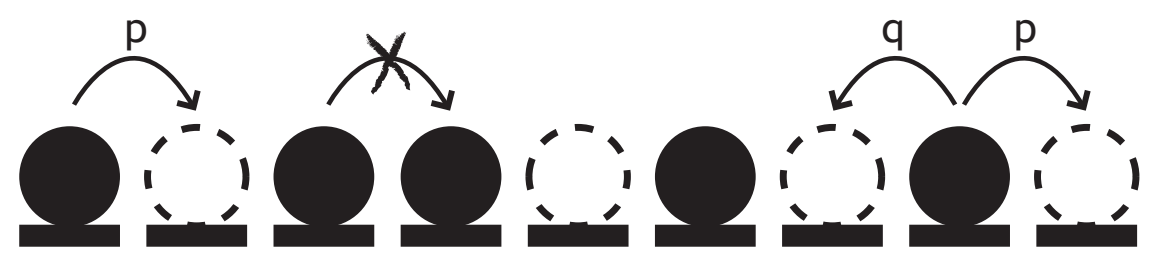

Figura 3.1: Modelo de transporte de partículas interagentes em redes unidimensionais do tipo ASEP. As partículas têm probabilidades diferentes, p e q, de saltar para os sítios vizinhos desocupados à direita e à esquerda respectivamente, e, se estes estiverem ocupados, a probabilidade de transição é nula. No modelo do tipo TASEP, a probabilidade de transição para um dos lados é nula (por exemplo, $q=0$ ).

\subsection{Conexão entre modelos mínimos e modelos do tipo ASEP e TASEP}

Tentaremos inicialmente mostrar como a conexão entre os modelos mínimos vistos no Capítulo 1 e os modelos do tipo ASEP pode ser feita. Para isso, partiremos do modelo proposto por Adjari e Prost (1993) [22] para um único motor, que foi estudado no Capítulo 1, e, após algumas aproximações, introduziremos a interação por volume excluído para, então, acharmos as probabilidades de transição ( $p$ e $q$ ), para cada intervalo de tempo $\tau$, que nos permitem uma descrição do sistema em termos de um modelo do tipo ASEP.

Como vimos no Capítulo 1, o modelo proposto por Adjari e Prost (1993) [22] consiste em supor que a interação entre o filamento e o motor possa ser representada por um potencial do tipo "dente-de-serra", periódico e assimétrico, de parâmetros $a$ e $b$, sendo $a$ a distância entre um mínimo e o máximo a sua esquerda e $b$ a distância entre um mínimo e o máximo a sua direita (ver Capítulo 1, Figura 1.1). Definimos aqui $l=a+b$, o período do potencial (a distância entre dois mínimos). Este potencial deve oscilar entre o estado "ligado" (em que o potencial percebido pela partícula é o dente-de-serra), e o "desligado" (em que o potencial percebido é liso), de acordo com o ruído atérmico, que representa a reação de hidrólise do ATP. Como agora estamos interessados em muitos motores que se movem simultaneamente sobre o mesmo filamento, visando deixar inicialmente este modelo o mais geral possível, associaremos inicialmente o ruído atérmico a cada sítio da rede de modo independente, modelando-o por uma variável $\sigma_{i}$ que pode assumir estocasticamente os valores 0 ou 1 , de modo que se $\sigma_{i}=0$ o potencial está "ligado" e se $\sigma_{i}=1$ o potencial está "desligado" no sítio $i$.

Assumimos, aqui também, equilíbrio local (aproximação adiabática), ou seja, se o potencial está "ligado", as partículas ficam presas ao poço em que se encontram (probabilidade de transição nula). Deste modo, quantificar a altura do poço torna-se irrelevante pois estamos considerando a barreira energética entre os poços infinitamente superior à energia 
térmica das partículas. Se o potencial está desligado, o ruído térmico passa a ser relevante e as partículas têm probabilidade igual de se difundir para direita ou para esquerda. Como o potencial é assimétrico $(a \neq b)$, isso implica em probabilidades de transição diferentes para o poço a sua direita ou a sua esquerda e fica fácil entender como tal potencial, sujeito ao ruído atérmico (que "liga" e "desliga" este potencial), gera o movimento vetorial das partículas. Vimos no Capítulo 1 como deve ser feito o cálculo exato para as probabilidades de transição de cada partícula. Como nos modelos do tipo ASEP as partículas se deslocam, a cada passo, no máximo de um sítio para o seguinte, consideraremos o regime de difusão lenta. Esta consideração parece ser razoável uma vez que, para a maioria dos motores em que se mediu a distância percorrida por passo dado, esta distância corresponde à distância encontrada entre os monômeros do filamento (ver por exemplo [48]), que no modelo é representada pela distância entre os poços $(l)$. Este regime de difusão lenta corresponde de fato ao TASEP, em que a partícula só pode se mover para o sítio a sua esquerda (consideraremos a partir daqui $a<b$, como no Capítulo 1) com probabilidade $p$ dada pela equação (1.19), ou ficar parada com probabilidade $1-p$.

Como nos intressamos pelo movimento bidirecional, achamos mais interessante considerar o modelo ASEP, que é um pouco mais geral e permite à particula saltar também para o sítio a sua direita. Para obter este modelo a partir do modelo de Adjari e Prost, o regime considerado deve ser um de difusão lenta (de modo que, a cada passo, as partículas não saltem mais do que um sítio para cada lado), mas não tão extremo que não permita o movimento para um dos lados, como o que foi resolvido por Adjari e Prost [22] e revisado no Capítulo 1. No período em que o potencial está desligado, vamos considerar que cada partícula pode, apenas, continuar no sítio em que está $(i)$ ou saltar para um dos sítios imediatamente vizinhos a ele $(i-1$ e $i+1)$. Assim, no intervalo de tempo em que o potencial "dente-de-serra" está desligado neste sítio da rede $\left(\sigma_{i}=0\right)$, as probabilidades de transição para o poço à esquerda e para aquele à direita ficam respectivamente dadas por:

$$
\begin{aligned}
q_{i \rightarrow i-1} & \equiv q_{i}=1-\int_{-a}^{\infty} p(z) d z \\
& =(1 / 2)-\int_{0}^{a} p(z) d z \\
p_{i \rightarrow i+1} & \equiv p_{i}=1-\int_{-\infty}^{b} p(z) d z \\
& =(1 / 2)-\int_{0}^{b} p(z) d z
\end{aligned}
$$

onde $p(z)$ é a distribuição gaussiana dada pela equação (1.5). A diferença entre estas 
probabilidades de transição é dada por:

$$
\begin{aligned}
q_{i}-p_{i} & =\int_{0}^{b} p(z) d z-\int_{0}^{a} p(z) d z \\
& =\int_{a}^{b} p(z) d z
\end{aligned}
$$

Vamos assumir agora que dentro dos limites desta integral a gaussiana é quase constante, de modo que podemos fazer a seguinte aproximação:

$$
q_{i}-p_{i}=\int_{a}^{b} p(z) d z \simeq(C / l)(b-a)
$$

Deste modo, estamos assumindo que a diferença entre as taxas de transição é proporcional à assimetria do potencial, sendo $C$ apenas uma constante (entre zero e um) e a divisão por $l$ apenas para manter esta constante adimensional e garantir que esta diferença entre as probabilidades de transição se mantenha entre zero e um (uma vez que $0<b-a<l$ ). Se olharmos diretamente as probabilidades de transição, esta aproximação se reflete em probabilidades que podem ser entendidas simplesmente por $p_{i}=C(a / l)$ e $q_{i}=C(b / l)$.

Introduzimos agora a interação do tipo volume excluído entre as partículas na rede. Atribuímos a cada partícula um raio $r$, de modo que o volume excluído implica que cada poço do potencial (de volume $l$ ) deve conter no máximo $l / r$ partículas. Sendo $n_{i}$ o número de partículas no poço $i$, temos que $\rho_{i}=n_{i}(r / l)$ é a fração ocupada do poço $i$ (que podemos chamar de densidade relativa). Incluindo a interação por volume excluído, as probabilidades de transição de cada partícula no poço $i$ saltar para o poço a sua direita $\left(p_{i}\right)$ ou para o poço a sua esquerda $\left(q_{i}\right)$, ficam respectivamente:

$$
\begin{gathered}
p_{i}=\sigma_{i} C(a / l)\left(1-\rho_{i+1}\right) \\
q_{i}=\sigma_{i} C(b / l)\left(1-\rho_{i-1}\right)
\end{gathered}
$$

Deste modo, a transição não ocorre no caso do potencial estar ligado $\left(\sigma_{i}=0\right)$ nem no caso do poço de destino estar totalmente ocupado $\left(\rho_{i+1}\right.$ ou $\left.i_{i-1}=1\right)$. Caso contrário, ela ocorre apenas se a partícula sujeita à difusão térmica conseguir percorrer a distância necessária até o poço seguinte.

Obtemos assim uma conexão entre o modelo proposto por Adjari e Prost e modelos do tipo ASEP/TASEP. A seguir, analisaremos o modelo ASEP obtido, tomando o limite do contínuo e fazendo uma aproximação de campo-médio, que nos dará uma equação diferencial quasi-linear. 


\subsection{A aproximação de campo médio e o limite contínuo para o modelo ASEP}

Na maioria dos modelos, dado que nos sistemas biológicos sempre temos no máximo um motor associado a cada monômero do filamento, toma-se $r=l$, de modo que se tem no máximo uma partícula por poço (e portanto teríamos $\rho=0$ ou $\rho=1$ ). Entretanto, a densidade $\rho_{i}$, variando continuamente entre 0 e 1 , continua sendo um conceito útil se a entendermos estatisticamente como uma densidade média de partículas no poço $i$. Esta média deve ser entendia como uma média de ensemble, no sentido utilizado em mecânica estatística (nunca como simplesmente uma média no tempo, uma vez que estamos interessados justamente na evolução temporal desta densidade).

A densidade média de partículas no poço $i$ em um instante $t+\tau$ é dada pela seguinte relação de recorrência:

$$
\rho_{i}(t+\tau)=\rho_{i}(t)+\rho_{i+1}(t) q_{i+1}(t)+\rho_{i-1}(t) p_{i-1}(t)-\rho_{i}(t)\left(p_{i}(t)+q_{i}(t)\right)
$$

Definido $A=C(a / l)$ e $B=C(b / l)$ temos, de modo mais explícito:

$$
\rho_{i}(t+\tau)=\rho_{i}+\rho_{i+1}\left(1-\rho_{i}\right) \sigma_{i+1} A+\rho_{i-1}\left(1-\rho_{i}\right) \sigma_{i-1} B-\rho_{i} \sigma_{i}\left[A\left(1-\rho_{i-1}\right)+B\left(1-\rho_{i+1}\right)\right]
$$

onde todos os termos do lado direito são tomados no instante $t$.

Podemos, então, escrever:

$$
\begin{aligned}
\frac{\rho_{i}(t+\tau)-\rho_{i}(t)}{\tau}= & \left(\frac{l}{\tau}\right) A\left\{\frac{\sigma_{i+1} \rho_{i+1}\left(1-\rho_{i}\right)-\sigma_{i} \rho_{i}\left(1-\rho_{i-1}\right)}{l}\right\} \\
& -\left(\frac{l}{\tau}\right) B\left\{\frac{\sigma_{i} \rho_{i}\left(1-\rho_{i+1}\right)-\sigma_{i-1} \rho_{i-1}\left(1-\rho_{i}\right)}{l}\right\}
\end{aligned}
$$

e definindo $\gamma=l / \tau$, com alguma álgebra, temos:

$$
\begin{aligned}
\frac{\rho_{i}(t+\tau)-\rho_{i}(t)}{\tau}= & \gamma A\left\{\frac{\left[\sigma_{i+1} \rho_{i+1}-\sigma_{i} \rho_{i}\right]-\left[\sigma_{i+1} \rho_{i+1}^{2}-\sigma_{i} \rho_{i}^{2}\right]}{l}\right. \\
& \left.+l \frac{\left[\sigma_{i+1} \rho_{i+1}\left(\rho_{i+1}-\rho_{i}\right)-\sigma_{i} \rho_{i}\left(\rho_{i}-\rho_{i-1}\right)\right]}{l^{2}}\right\} \\
& -\gamma B\left\{\frac{\left[\sigma_{i} \rho_{i}-\sigma_{i-1} \rho_{i-1}\right]-\left[\sigma_{i} \rho_{i}^{2}-\sigma_{i-1} \rho_{i-1}^{2}\right]}{l}\right. \\
& \left.-l \frac{\left[\sigma_{i} \rho_{i}\left(\rho_{i+1}-\rho_{i}\right)-\sigma_{i-1} \rho_{i-1}\left(\rho_{i}-\rho_{i-1}\right)\right]}{l^{2}}\right\}
\end{aligned}
$$

Para que consigamos, ao tomar o limite do contínuo, uma forma mais compacta e simples para esta equação, teremos que abrir mão da generalidade que a variável $\sigma_{i}$, com valores 
independentes para a cada sítio $i$, dava ao modelo. Isto pode ser feito tomando-se a média para variáveis $\sigma_{i}$, supondo que elas sejam estatisticamente independentes e igualmente distribuídas. Sendo $\bar{\sigma}$ o valor médio para todo $i$, e tomando o limite de $l \rightarrow 0$ e $\tau \rightarrow 0$ com $\gamma$ constante, temos:

$$
\begin{aligned}
\frac{\partial \rho}{\partial t} & =\gamma(A-B) \bar{\sigma}\left[\frac{\partial \rho}{\partial x}-\frac{\partial \rho^{2}}{\partial x}\right] \\
& =K \frac{\partial}{\partial x}[\rho(x, t)(1-\rho(x, t))]
\end{aligned}
$$

onde definimos $K=\gamma(A-B) \bar{\sigma}$, K é, portanto, uma constante proporcional ao grau de assimetria do potencial.

Uma vez que o número de partículas se conserva no interior do sistema considerado, a equação (3.15) pode ser vista como uma equação de continuidade:

$$
\frac{\partial \rho}{\partial t}=-\frac{\partial j}{\partial x}
$$

onde identificamos

$$
j(x, t)=-K \rho(x, t)(1-\rho(x, t))
$$

que deve ser entendido como o fluxo de partículas (ou corrente) através de uma secção transversal do filamento no ponto $x$, num instante $t$. Este conceito será utilizado posteriormente.

Essa equação diferencial quasi-linear que encontramos para a evolução da densidade média de partículas num ponto num dado instante é conhecida em mecânica dos fluidos como equação de Burgers no limite não-viscoso [74]. Ela também é obtida (apenas com uma constante $\mathrm{K}$ diferente) se tomarmos o limite do contínuo para o modelo TASEP [35], [38], ou seja, ela representa tanto o modelo ASEP como o TASEP neste limite. As diversas soluções desta equação são muito susceptíveis às condições iniciais. Em particular, como será visto na próxima seção, de acordo com a condição inicial, ou com as condições de contorno, as características dessa equação (ver Apêndice A) podem apresentar choques. Parmeggiani et al. (2004) [80], analisando o limite estacionário desta equação, associaram esse choque à coexistência de duas fases ao longo do filamento, uma com baixa densidade de partículas e outra com alta densidade. Esse comportamento, com a presença de duas fases, é observado também em simulações numéricas do modelo discreto [33]. Esta coexistência de fases foi recentemente observada num experimento realizado com muitos motores (kinesinas) que se deslocam simultaneamente sobre um mesmo filamento [32], como já citado acima. Conforme o modelo exposto no próximo capítulo, achamos que estas fases que apresentam regiões com densidades distintas de motores co-existindo podem estar relacionadas ao movimento bidirecional observado para objetos intracelulares. 


\subsection{Diagrama de fases para o ASEP}

De fato, já na década de 1990 percebeu-se que os estados estacionários de modelos do tipo ASEP e TASEP poderiam, em certas condições (ou após algumas modificações), apresentar esta transição de fase entre fases de densidade homogênea e fases heterogêneas (com regiões de densidades distintas ao longo da rede) [34], [81], [82]. O fato de isto ocorrer em modelos unidimensionais chamou muita atenção no campo da mecânica estatística de não-equilíbrio. Isso se deve principalmente à contraposição com sistemas unidimensionais com interações de curto alcance e que obedecem condições de balanço detalhado (evoluindo então para estados de equilíbrio), uma vez que, sabidamente, tais sistemas não podem apresentar ordenação de fases (a não ser no limite de temperatura zero) [38], [79]. Assim, muitos pesquisadores se dedicaram ao estudo destes modelos e suas variantes, que podem ser as mais diversas, por exemplo, com introdução defeitos na rede (podem haver sítios onde as taxas de transição são modificadas, algo parecido com o que tentamos inicialmente, quando assumimos taxas $\sigma_{i}$ indepentes) ou nos motores (que podem se mover com taxas diferentes) [83], [84], [85].

Uma modificação ao modelo do ASEP que merece ser mencionada é aquela feita por Parmeggiani et al. (2003) [33] que, buscando um modelo mais próximo ao que ocorre com os motores moleculares se deslocando sobre microtúbulos, associaram à dinâmica do ASEP uma dinâmica de Langmuir, de modo que as partículas podem, a cada instante, sair da rede (não havendo mais conservação do número de partículas no interior da rede), além de se mover lateralmente na rede. Esta dinâmica tenta trazer ao modelo a processividade que limita muitas vezes o movimento dos motores (apesar disto aparentemente não ocorrer no transporte bidirecional intracelular, como dissemos no Capítulo 2). Este modelo também apresenta a transição de fase mencionada acima.

Desenvolveu-se, então, um método que permite obter a solução exata (sem a aproximação de campo-médio) para a condição estacionária do modelo do TASEP descrito por Derrida et al. [35]. Não nos aprofundaremos no estudo deste método pois, apesar de exato, ele é aplicado para se obter soluções do modelo no caso estacionário e, como ficará claro no próximo capítulo, nós estamos interessado na evolução temporal das soluções que este modelo pode apresentar. Mais precisamente, estamos interessados na evolução temporal dos possíveis choques (regiões em que a densidade de partículas apresenta descontinuidade).

Mas, antes disso, para mostrar que a equação (3.15) ainda guarda a essência dos modelos ASEP e TASEP, vamos obter o diagrama de fases do TASEP para condições abertas de contorno, no limite estacionário, que foi obtido por Derrida et al. (1993) [35] com seu método exato. Como uma das fases do diagrama apresenta um choque, esta é uma oportunidade para exemplificar este fenômeno já tão citado. 


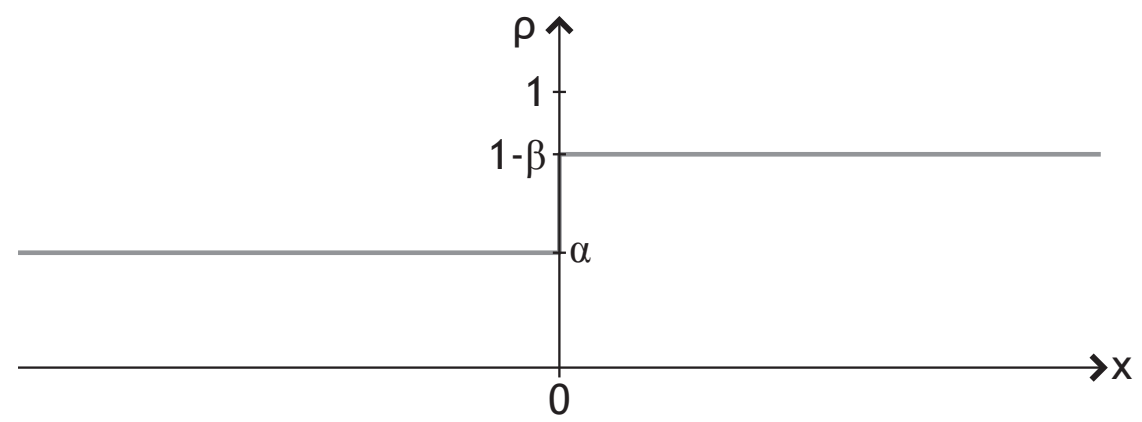

Figura 3.2: Condição inicial do tipo "degrau". Ilustramos a condição inicial $\rho(x, 0)=\alpha$ para $x<0$ e $\rho(x, 0)=1-\beta$ para $x>0$ para o caso $\alpha<1 / 2$ e $\beta<1 / 2$.

A equação (3.15) pode ser escrita da forma mais econômica:

$$
\frac{\partial \rho(x, t)}{\partial t}=K(1-2 \rho(x, t)) \frac{\partial \rho(x, t)}{\partial x}
$$

que nos permite visualisar mais facilmente a forma das características (ver Apêndice A), que descrevemos a seguir. Deste ponto em diante consideramos $K>0$.

Consideramos a variável espacial $x$ definida em toda a reta dos números reais $(x \in \mathbf{R})$ e, utilizando o método das caracteríscas [86] (este método está descrito no Apêndice A), estudamos a evolução da equação (3.18) partindo de condições iniciais descontínuas, do tipo "degrau", com densidade $\alpha$ para $x$ negativo e $1-\beta$ para $x$ positivo (ver Figura 3.2). Com isso, as curvas características da equação (3.18) acima ficam dadas por:

$$
\begin{aligned}
x(t) & =-K(1-2 \alpha) t+x_{0} \quad \text { para } x_{0}<0 \mathrm{e} \\
x(t) & =-K(1-2(1-\beta)) t+x_{0} \\
& =K(1-2 \beta) t+x_{0} \quad \text { para } x_{0}>0
\end{aligned}
$$

Temos então, de acordo com o sinal do coeficiente angular de cada característica, quatro regiões no espaço dos parâmetros $\alpha$ x $\beta$ que nos darão soluções distintas no limite de tempos longos:

- para $\alpha<\frac{1}{2}$ e $\beta<\frac{1}{2}$, temos uma solução do tipo:

$$
\begin{aligned}
\rho(x, t) & =\alpha \text { para } x<-K(1-2 \alpha) t \\
\rho(x, t) & =\frac{1}{2}\left(1+\frac{x}{K t}\right) \text { para }-K(1-2 \alpha) t<x<K(1-2 \beta) t \\
\rho(x, t) & =1-\beta \text { para } x>K(1-2 \beta) t
\end{aligned}
$$

A solução para valores intermediários de $x$ corresponde a uma região de rarefação (ver Apêndice A). No limite para $t \rightarrow \infty$, correspondente ao estado estacionário, 
temos: $\rho(x, t)=\frac{1}{2}$. Esta fase é chamada de fase de corrente máxima, uma vez que a corrente de partículas (fluxo) é dada por $j=-K \rho(1-\rho)$ (ver equação (3.17)), nessa fase temos então a corrente máxima $j=\frac{1}{4}$.

- para $\alpha<\frac{1}{2}$ e $\beta>\frac{1}{2}$, temos novamente uma solução dada pelas equações (3.20) obtidas acima. Entretanto, com os novos valores de $\alpha$ e $\beta$, no limite para $t \rightarrow \infty$, obtemos: $\rho(x, t)=1-\beta$. Essa é a chamada fase de baixa densidade.

- para $\alpha>\frac{1}{2}$ e $\beta<\frac{1}{2}$, temos, mais uma vez, uma solução dada pelas equações (3.20), o que agora, no limite para $t \rightarrow \infty$, nos dá: $\rho(x, t)=\alpha$. Essa é a chamada fase de alta densidade.

- para $\alpha>\frac{1}{2}$ e $\beta>\frac{1}{2}$, temos um choque entre as duas características em $t_{s}=0$ e $x_{s}=0$. A condição de Rankine-Hugoniot (ver Apêndice A) para a velocidade do choque fica

$$
\begin{aligned}
\frac{d x_{s}}{d t} & =\frac{j\left(x_{s^{+}}, t\right)-j\left(x_{s^{-}}, t\right)}{\rho\left(x_{s^{+}}, t\right)-\rho\left(x_{s^{-}}, t\right)} \\
& =-K \frac{(1-\beta)[1-(1-\beta)]-\alpha(1-\alpha)}{(1-\beta)-\alpha} \\
& =-K(\beta-\alpha)
\end{aligned}
$$

e, portanto, a posição do choque é descrita por $x_{s}(t)=-K(\beta-\alpha) t$. Temos assim uma solução à direita e outra à esquerda do choque, ou seja:

$$
\begin{aligned}
& \rho(x, t)=\alpha \text { para } x<-K(\beta-\alpha) t \\
& \rho(x, t)=1-\beta \text { para } x>-K(\beta-\alpha) t
\end{aligned}
$$

Para $\alpha=\beta$ temos um choque estacionário em $x_{s}(t)=0$, que nos dá como solução, no limite para tempos longos, a co-existência de duas fases, uma região de alta densidade $(\rho=\alpha$ para $x<0)$ e uma região de baixa densidade $(\rho=\beta$ para $x>0)$. Para $\alpha \neq \beta$ o choque irá se mover e uma das fases (dependendo do sentido da velocidade do choque) irá predominar no limite de $t \rightarrow \infty$.

Conseguimos assim obter como limite para tempos longos o mesmo diagrama de fases descrito por Derrida et al. [35] para o TASEP no caso estacionário, onde o modelo é estudado com condições abertas de fronteira. Vemos que, para isso, os parâmetros de controle do modelo que no caso de [35] são dados nas condições de contorno na forma de taxa de entrada $\alpha$ no primeiro sítio da rede e taxa de saída $\beta$ do último sítio, aqui devem ser introduzidos na condição inicial que deve ser descontínua (do tipo "degrau"). Este diagrama está mostrado na Figura 3.3.

No próximo capítulo propomos um novo modelo para o entendimento do movimento bidirecional de objetos intracelulares a partir da evolução temporal dos "choques" que 


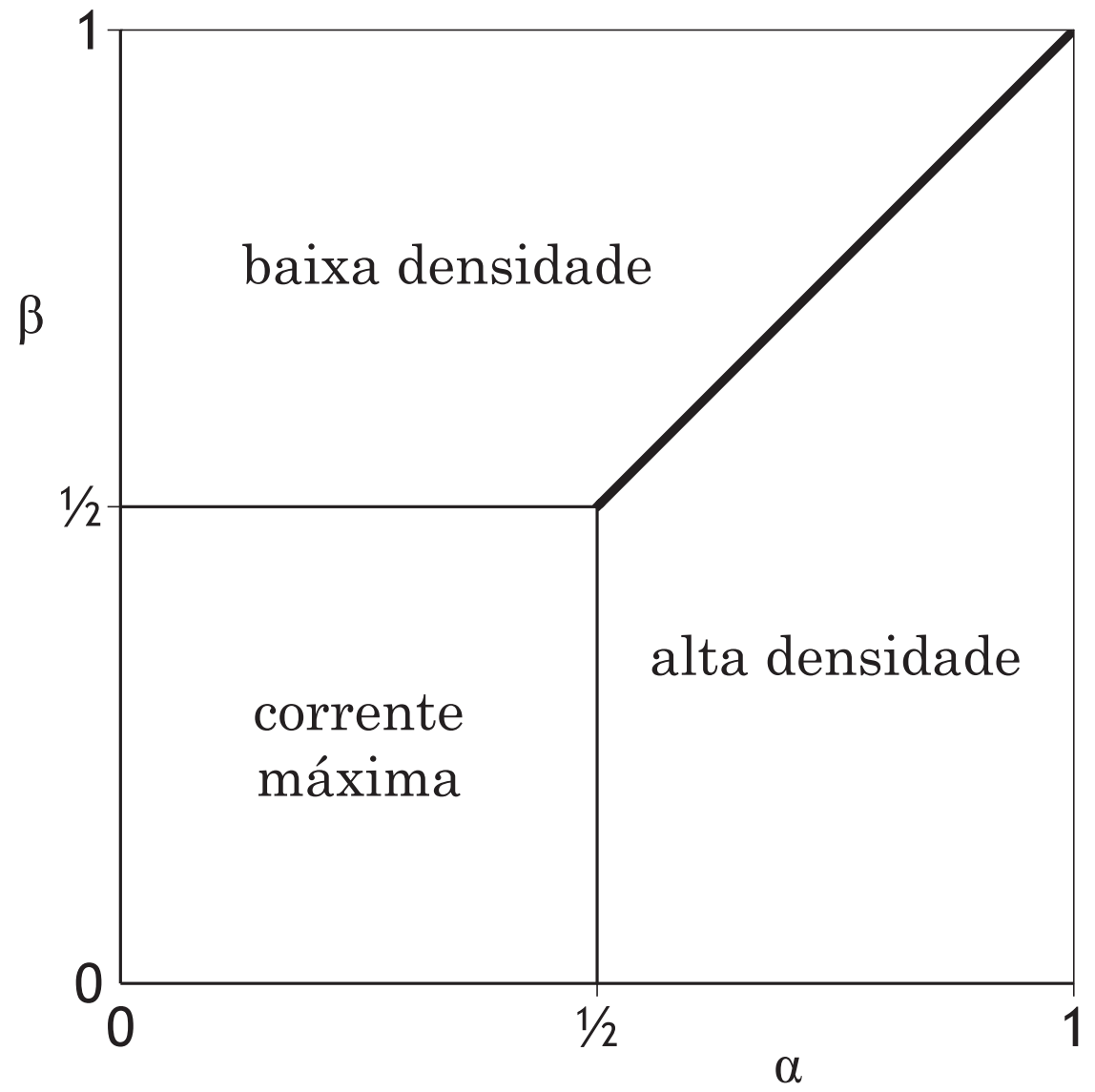

Figura 3.3: Diagrama de fases para o estado estacionário do modelo TASEP. Conforme explicado no texto, temos três fases: corrente máxima (para $\alpha<1 / 2$ e $\beta<1 / 2$ ), baixa densidade (para $\beta>1 / 2$ e $\alpha<\beta$ ) e alta densidade $(\alpha>1 / 2$ e $\beta<\alpha)$. 
ocorrem entre as características da equação (3.18), para certas condições iniciais, distintas das que consideramos aqui para obter o diagrama de fases. O fato de termos obtido aqui este diagrama de fases valida o estudo do modelo TASEP através da equação de Burgers (3.15), mesmo se tratando de uma aproximação deste modelo no limite contínuo. Isto nos permitirá estudar os estados transientes deste sistema, com uma boa parametrização do movimento dos choques existentes. 


\section{Capítulo 4}

\section{O movimento de vesículas: deslizando na crista da onda de choque}

\subsection{Explicação alternativa para o movimento bidire- cional mediado por motores moleculares}

Como vimos no Capítulo 2, tem-se observado a bidirecionalidade no transporte de vesículas e organelas intracelulares em diversas situações. Vimos que existem algumas propostas de mecanismos que explicam este fenômeno, sendo mais aceita aquela que considera a existência de complexos proteicos que coordenem a atividade dos diferentes tipos de motores que, supõem-se, estejam localizados simultaneamente na superfície do objeto transportado (seja ele uma vesícula, uma organela, uma macromolécula ou um vírus). Entretanto, ainda não se esclareceu como se dá esta coordenação entre as atividade dos motores de diferentes tipos, de modo que esta questão permanece em aberto. Pode-se imaginar diversos outros fenômenos que podem interferir neste movimento. Por exemplo, os experimentos in vivo não conseguiram excluir a possibilidade de motores que não estejam ligados diretamente à vesícula - "motores livres" - , mas que podem, de acordo com experimentos in vitro, se deslocar sobre o filamento, modificarem o movimento desta. Apesar dos modelos vigentes (revistos no Capítulo 2) suporem que somente os motores presos à vesícula têm papel relevante no movimento desta, apenas um experimento [30] parece ter mostrado que o movimento bidirecional pode ocorrer mesmo em um sistema onde não se encontram motores livres (neste experimento oberserva-se movimento bidirecional com vesículas purificadas, sem adição posterior de motores). Entretanto, os experimentos realizados com sistemas experimentais diferentes quase sempre apresentam resultados tão diversos que não se pode excluir a possibilidade de um modelo que explique o movimento bidirecional 
num sistema não se mostrar suficiente para explicá-lo em outro, sendo possivelmente necessários vários modelos para explicar este fenômeno.

Propomos aqui uma explicação alternativa e original para o fenômeno da bidirecionalidade observada no transporte de objetos intracelulares ${ }^{1}$. Esta explicação tem por base a interação entre os vários motores que se deslocam num mesmo filamento e, por isso, nos baseamos nos modelos do tipo ASEP e TASEP descritos no capítulo anterior. Acreditamos que fenômenos nada triviais que podem surgir desta interação das partículas motoras, como a coexistência de regiões de alta e baixa densidades, podem estar na origem da bidirecionalidade do movimento destes objetos.

Buscamos dar uma explicação teórica alternativa para estes movimentos, que seja ao mesmo tempo geral (não dependendo do tipo de motor nem do tipo de objeto transportado) e versátil, possibilitando que tanto movimentos bidirecionais in vivo como in vitro sejam explicados. Inspirados pelas idéias apresentadas no modelo do capítulo anterior e principalmente no modelo analisado por Derrida et al. [38], conseguimos explicar este tipo de movimento observado como estados transientes de um modelo do tipo TASEP (tratado numa aproximação de campo-médio e no limite do contínuo) perturbado num instante inicial pela própria presença da vesícula, que seria então carregada pelo choque entre as regiões de baixa e alta densidade de motores.

O modelo que Derrida et al. [38] resolveram de modo exato foi proposto com o objetivo de estudar a dinâmica microscópica dos choques observados no TASEP simples [36], [37]. Isso foi feito através da modificação do TASEP pela introdução de um segundo tipo de partícula cuja dinâmica é tal que elas tendem a se localizar na região do choque, servindo como sondas microscópicas deste. Assim, este modelo considera partículas de duas espécies que se movem sobre um mesmo filamento. As partículas de primeira espécie (do tipo 1) se comportam como um TASEP (de acordo com a dinâmica (3.1) com $q=0$ ), ou seja, se deslocam para o sítio da rede à direita com taxa $p$, se este estiver vazio, e não podem se deslocar para a esquerda ou para sítios ocupados por partículas do tipo 1. As partículas de segunda espécie (do tipo 2), no caso de se encontrarem numa região sem partículas do tipo 1, também se comportam como um TASEP, entretanto, se comportam como buracos quando estão num sítio adjacente a uma partícula do tipo 1 (de modo que elas não modificam o TASEP representado pelas partículas do tipo 1 isoladamente).

De modo análogo ao indicado para o ASEP na dinâmica (3.1), pode-se descrever a dinâmica deste modelo associando para cada sítio uma variável que assume os valores 0, 1 ou 2 de acordo com o estado de ocupação deste sítio (0 se o sítio está vazio, 1 se este sítio está ocupado por uma patícula do tipo 1 e 2 se está ocupado por uma partícula do

\footnotetext{
${ }^{1}$ objetos intracelulares: como o principal sistema experimental estudado por nós foi aquele descrito no Capítulo 2, que trata do transporte intracelular de vesículas lipídicas, trataremos o objeto transportado por vesículas, mas o modelo teórico proposto não faz nenhuma distinção no tipo de objeto transportado.
} 
tipo 2). O sistema irá evoluir de modo que, a cada instante de tempo $d t$, os seguintes eventos podem ocorrer para dois sítios vizinhos na rede:

$$
\begin{aligned}
& (1)_{i}(0)_{i+1} \rightarrow(0)_{i}(1)_{i+1} \text { com probalidade } p d t \\
& (2)_{i}(0)_{i+1} \rightarrow(0)_{i}(2)_{i+1} \text { com probalidade } p d t \\
& (1)_{i}(2)_{i+1} \rightarrow(2)_{i}(1)_{i+1} \text { com probalidade } p d t
\end{aligned}
$$

Deste modo, as partículas do tipo 1 apresentam a dinâmica de um TASEP, já estudada por nós no capítulo anterior, apresentando choques entre regiões de baixa e alta densidades, de acordo com as condições iniciais (ou, no caso estacionário de um sistema com condições abertas de fronteira, de acordo com as condições de contorno); já as particulas do tipo 2, por se comportarem como buracos quando na presença daquelas do tipo 1 e como partículas quando em regiões desocupadas, tendem a ocupar as regiões de interface entre as regiões de baixa e de alta densidade de partículas do tipo 1. Verificou-se, com este modelo, que as partículas do tipo 2 funcionam como sondas microscópicas do choque, que continua existindo mesmo nessa escala (a descontinuidade na densidade de partículas do tipo 1 é abrupta mesmo microscopicamente) [37].

Nós tomamos este modelo como base para sugerir uma nova explicação para o fenômeno da bidirecionalidade no transporte de vesículas. Entretanto, diferentemente de Derrida et al., não estamos interessados na dinâmica das partículas do tipo 2 apenas como sondas do choque. Sugerimos que cada partícula do tipo 2 seja interpretada como representando a própria vesícula lipídica ou, de modo global, aqueles motores ligados a uma vesícula. Deste modo, estamos propondo que a vesícula seja carregada pelas variações na densidade de motores moleculares livres que se movem sobre o filamento (ou seja, as vesículas acompanhariam o movimento dos choques). Supomos, portanto, que os motores ligados à vesícula se comportam de modo diverso daqueles que interagem apenas com os filamentos, com uma dinâmica tal que a localizam na posição dos choques formados entre regiões de alta densidade e de baixa densidade de motores livres. Como supomos que a vesícula está acompanhando a onda de choque, denominamos esse processo de "surfing", em analogia ao processo descrito por [63] no qual uma proteína associada ao motor desliza sobre o filamento, por eles denominado "skating".

\subsection{Solução da equação de Burgers para uma condição inicial especial}

Nós estamos interessados nos estados transientes do sistema e, em especial, no movimento apresentado pelos choques, mas não na dinâmica microscópica por eles apresentada. Portanto, não trataremos este modelo do modo feito por Derrida et al. [38] (que obtiveram 
a solução exata para estado estacionário do sistema). Vamos nos preocupar em estudar apenas o TASEP formado pelas partículas do tipo 1, supondo que as vesículas se movem de acordo com o movimento dos choques presentes. Este TASEP será considerado no limite do contínuo e com aproximação de campo-médio, de modo que, de acordo com os resultados do capítulo anterior, trata-se de resolver, para determinadas condições iniciais, a seguinte equação:

$$
\frac{\partial \rho(x, t)}{\partial t}=-(1-2 \rho(x, t)) \frac{\partial \rho(x, t)}{\partial x}
$$

Esta equação nada mais é do que a equação de Burgers (3.18), tomando $K=-1$, onde, vale lembrar, $\rho(x, t)$ representa a densidade média de partículas do tipo 1 (entendidas como "motores livres") no ponto $x$ e instante $t$. Nesse estudo, assim como na obtenção do diagrama de fases do capítulo anterior, utilizamos o método das características [86], descrito no Apêndice A.

Consideramos o sistema como um filamento infinito (de modo que não precisamos considerar os problemas gerados pelas condições de contorno), com uma densidade de motores moleculares inicialmente constante ao longo do filamento. Tal estado inicial equivale a um TASEP simples com densidade uniforme. Assumiremos que esta densidade inicial seja igual a $1 / 2$, de modo que o fluxo de partículas é máximo, como demonstrado no capítulo anterior (ver Figura 3.3), o que pode ser biologicamente interessante. Supomos que, num dado instante, a aproximação de uma vesícula causa uma perturbação na densidade destes motores, mudando a dinâmica deste sistema, que passa a apresentar um estado transiente, o qual será analisado a partir daqui (veremos que para tempos longos o sistema retornará ao estado estacionário de densidade uniforme igual a 1/2). Ou seja, estamos interessados nas soluções dependentes do tempo da equação de Burgers, equação (4.2), partindo de uma condição inicial que deve representar uma perturbação da densidade de partículas em torno da densidade inicial de $1 / 2$.

A condição inicial considerada tem da seguinte forma:

$$
\begin{aligned}
& \rho(x, 0)=1 / 2 \text { para } x<0 \\
& \rho(x, 0)=1 / 2-\varepsilon \text { para } 0<x<2 a \\
& \rho(x, 0)=1 / 2 \text { para } 2 a<x<3 a \\
& \rho(x, 0)=1 / 2+\varepsilon \text { para } 3 a<x<4 a \\
& \rho(x, 0)=1 / 2 \text { para } 4 a>x
\end{aligned}
$$

e define o perfil de densidade de motores mostrado na Figura 4.1.

As características da equação (4.2) são, de modo geral, dadas por:

$$
x(t)=\left(1-2 \rho_{0}\left(x_{0}\right)\right) t+x_{0}
$$




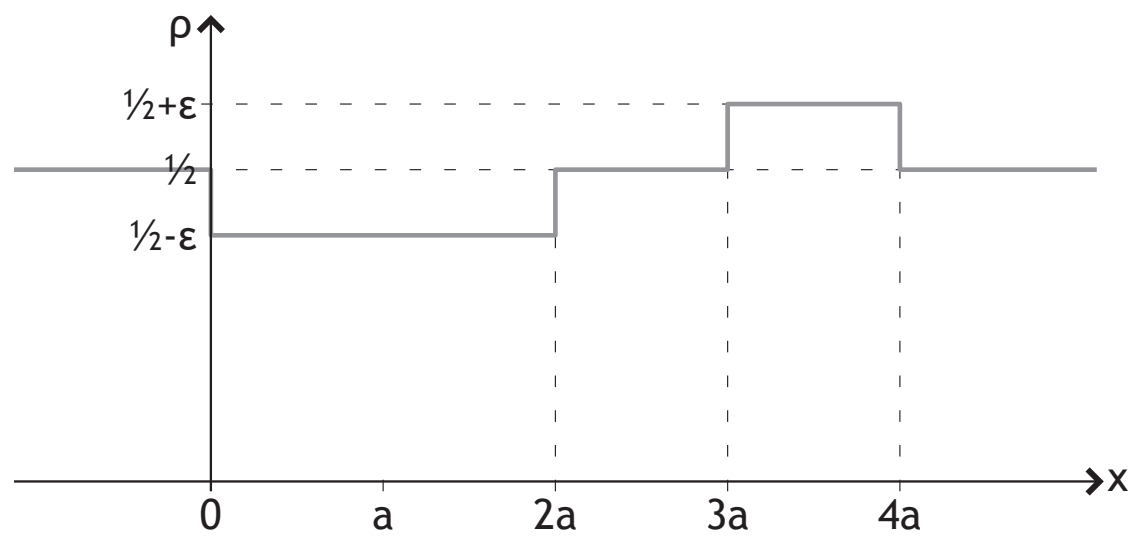

Figura 4.1: Perfil de densidade definido pela condição inicial (4.3). Em nosso modelo supomos que este perfil represente a perturbação que a vesícula causa na densidade estacionária de motores, que consideramos igual a 1/2 (de modo que o fluxo de motores no estado estacionário é máximo).

A condição inicial dada na equação (4.3) define, então, de acordo com as regiões em que $\rho_{0}$ assume valores constantes, diferentes famílias de características (que se movem com velocidades diferentes). Estas famílias ficam, portanto, dadas por:

$$
\begin{aligned}
& x_{1}(t)=x_{0} \text { para } x_{0}<0 \\
& x_{2}(t)=x_{0}+2 \varepsilon t \text { para } 0<x_{0}<2 a \\
& x_{3}(t)=x_{0} \text { para } 2 a<x_{0}<3 a \\
& x_{4}(t)=x_{0}-2 \varepsilon t \text { para } 3 a<x_{0}<4 a \\
& x_{5}(t)=x_{0} \text { para } 4 a<x_{0}
\end{aligned}
$$

Estas curvas estão representadas na Figura 4.2, onde estão representados também os choques entre as características e as regiões de rarefação, discutidos a seguir.

Vemos que ocorrem choques entre famílias de características que se aproximam (ou seja, os choques separam regiões de densidades diferentes) e regiões de rarefação localizadas entre famílias de características que se distanciam. Estamos interessados justamente nestes fenômenos, que surgem pelo fato da equação (4.2) ser não-linear (devido, portanto, às intereções entre as partículas), a seguir faremos, então, uma análise cuidadosa do movimento deles.

Logo no instante inicial $(t=0)$ teremos dois choques:

- choque $1\left(x_{c 1}(t)\right)$ em $x_{c 1}(0)=2 a$, entre as características $x_{2}$ e $x_{3}$ :

A condição de Rankine-Hugoniot [86] (ver Apêndice A) nos dá a velocidade deste 


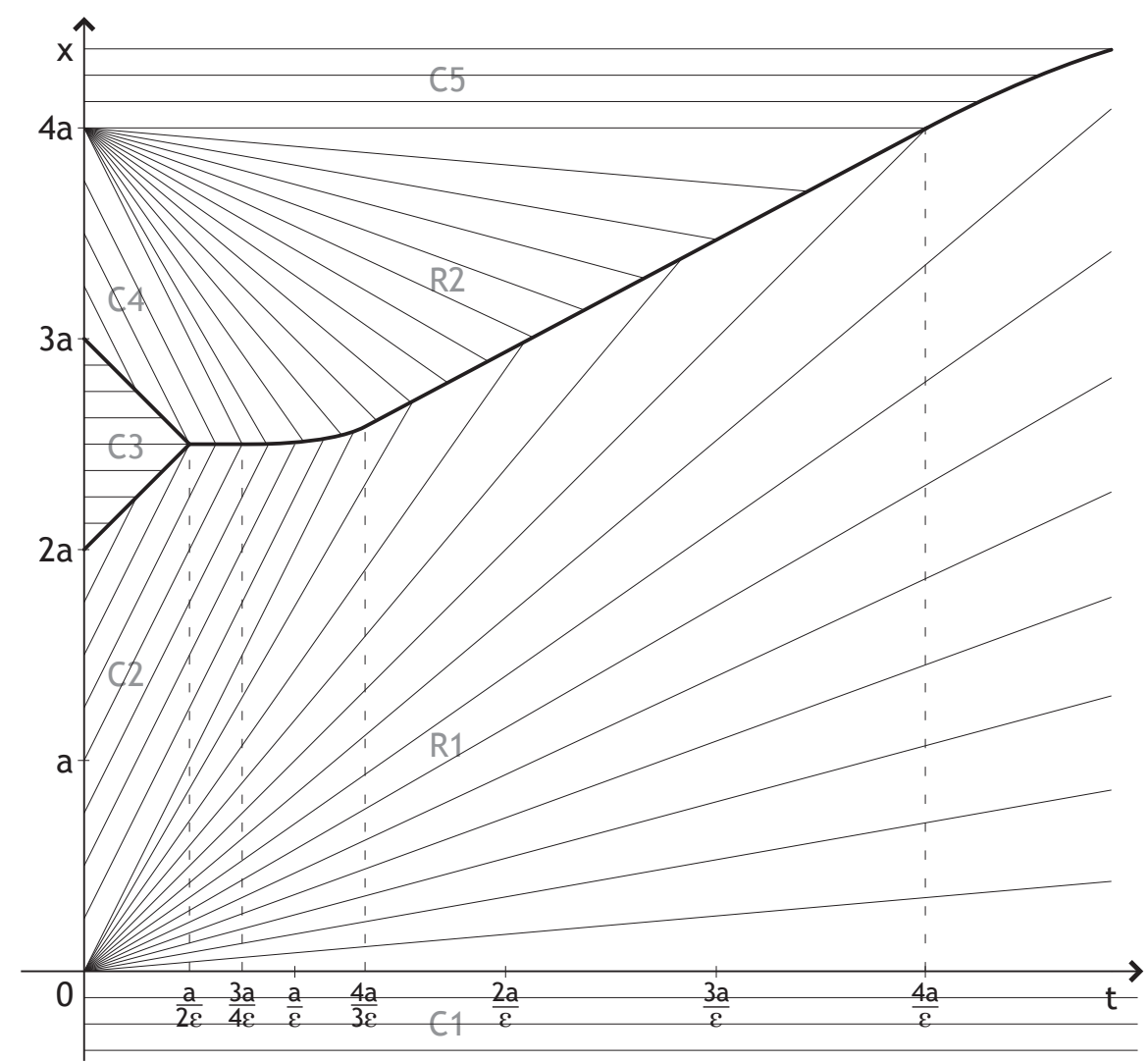

Figura 4.2: Mapa de características obtido, conforme explicado no texto, pelo método das características (descrito no Apêndice A) para a equação (3.18), dada condição inicial (4.3). Indicamos as regiões de rarefação 1 e 2 respectivamente por $\mathrm{R} 1$ e $\mathrm{R} 2$, e as famílias de características $x_{1}, x_{2}, x_{3}, x_{4}$ e $x_{5}$ da equação (4.5) pelas letras C1, C2, C3, C4 e C5, respectivamente. A linha preta mais espessa indica os choques entre as características, as linhas pontilhadas indicam os instantes iniciais dos choques (ver Tabela 4.1): $t_{3}^{0}=\frac{a}{2 \varepsilon}, t_{4}^{0}=\frac{3 a}{4 \varepsilon}$, $t_{5}^{0}=\frac{4 a}{3 \varepsilon}, t_{6}^{0}=\frac{4 a}{\varepsilon}$. 
choque:

$$
\begin{aligned}
\frac{d x_{c 1}}{d t} & =\frac{j\left(\rho\left(x_{3}\right)\right)-j\left(\rho\left(x_{2}\right)\right)}{\rho\left(x_{3}\right)-\rho\left(x_{2}\right)} \\
& =\frac{(1 / 2)(1-1 / 2)-(1 / 2-\varepsilon)[1-(1 / 2-\varepsilon)]}{1 / 2-(1 / 2-\varepsilon)}=\varepsilon
\end{aligned}
$$

e temos então:

$$
x_{c 1}(t)=2 a+\varepsilon t
$$

- choque $2\left(x_{c 2}(t)\right)$ em $x_{c 2}(0)=3 a$, entre as características $x_{3}$ e $x_{4}$ :

A velocidade deste choque fica dada por:

$$
\begin{aligned}
\frac{d x_{c 2}}{d t} & =\frac{j\left(\rho\left(x_{4}\right)\right)-j\left(\rho\left(x_{3}\right)\right)}{\rho\left(x_{4}\right)-\rho\left(x_{3}\right)} \\
& =\frac{(1 / 2+\varepsilon)[1-(1 / 2+\varepsilon)]-(1 / 2)(1-1 / 2)}{(1 / 2+\varepsilon)-1 / 2}=-\varepsilon
\end{aligned}
$$

e temos então:

$$
x_{c 2}(t)=3 a-\varepsilon t
$$

Temos também, ainda em $t=0$, a formação de duas regiões de rarefação:

- rarefação $1\left(x_{r 1}(t)\right)$ em $x_{r 1}(0)=0$, na região entre as características $x_{1}$ e $x_{2}$, dada por:

$$
x_{r 1}(t)=\left(1-2 \rho_{r 1}\right) t \text { para } 1 / 2-\varepsilon<\rho_{r 1}<1 / 2
$$

e portanto

$$
\rho_{r 1}\left(t, x_{r 1}\right)=1 / 2-\frac{x_{r 1}}{2 t} \text { para } 0<x_{r 1}<2 \varepsilon t
$$

- rarefação $2\left(x_{r 2}(t)\right)$ em $x_{r 2}(0)=4 a$, na região entre as características $x_{4}$ e $x_{5}$, dada por:

$$
x_{r 2}(t)=4 a+\left(1-2 \rho_{r 2}\right) t \text { para } 1 / 2<\rho_{r 2}<1 / 2+\varepsilon
$$

e portanto

$$
\rho_{r 2}\left(t, x_{r 2}\right)=1 / 2+\frac{4 a-x_{r 2}}{2 t} \text { para } 4 a-2 \varepsilon t<x_{r 2}<4 a
$$

Teremos então um novo choque quando os choques $x_{c 1}(t)$ e $x_{c 2}(t)$ se encontram:

- choque $3\left(x_{c 3}(t)\right)$ que ocorre no instante $t_{3}^{0}$ determinado pela relação:

$$
x_{c 1}\left(t_{3}^{0}\right)=x_{c 2}\left(t_{3}^{0}\right)
$$


ou seja,

$$
\begin{aligned}
2 a+\varepsilon t_{3}^{0} & =3 a-\varepsilon t_{3}^{0} \\
t_{3}^{0} & =a / 2 \varepsilon
\end{aligned}
$$

A velocidade deste choque será dada por:

$$
\begin{aligned}
\frac{d x_{c 3}}{d t} & =\frac{j\left(\rho\left(x_{4}\right)\right)-j\left(\rho\left(x_{2}\right)\right)}{\rho\left(x_{4}\right)-\rho\left(x_{2}\right)} \\
& =\frac{(1 / 2+\varepsilon)[1-(1 / 2+\varepsilon)]-(1 / 2-\varepsilon)[1-(1 / 2-\varepsilon)]}{(1 / 2+\varepsilon)-(1 / 2-\varepsilon)}=0
\end{aligned}
$$

e portanto este choque permanece parado em sua posição inicial:

$$
x_{c 3}(t)=x_{c 1}\left(t_{3}^{0}\right)=5 a / 2
$$

Entretanto, teremos um novo choque no instante $t_{4}^{0}$ em que este terceiro choque encontrar a característica da família $x_{4}$ que parte de $x_{0}=4 a$, ou seja, o quarto choque ocorre entre as características da segunda região de rarefação e aquelas da família $x_{2}$.

- choque $4\left(x_{c 4}(t)\right)$ que, portanto, ocorre no instante determinado através da relação:

$$
x_{c 3}\left(t_{4}^{0}\right)=x_{r 2}\left(\rho=1 / 2+\varepsilon ; t_{4}^{0}\right)
$$

ou seja,

$$
\begin{aligned}
5 a / 2 & =4 a-2 \varepsilon t_{4}^{0} \\
t_{4}^{0} & =3 a / 4 \varepsilon
\end{aligned}
$$

De acordo com a condição de Rankine-Hugoniot, este choque tem velocidade dada por:

$$
\begin{aligned}
\frac{d x_{c 4}}{d t} & =\frac{j\left(\rho_{r 2}\left(x_{c 4}\right)\right)-j\left(\rho\left(x_{4}\right)\right)}{\rho_{r 2}\left(x_{c 4}\right)-\rho\left(x_{4}\right)} \\
& =\frac{\left(1 / 2+\frac{4 a-x_{c 4}}{2 t}\right)\left[1-\left(1 / 2+\frac{4 a-x_{c 4}}{2 t}\right)\right]-(1 / 2-\varepsilon)[1-(1 / 2-\varepsilon)]}{\left(1 / 2+\frac{4 a-x_{c 4}}{2 t}\right)-(1 / 2-\varepsilon)} \\
& =\varepsilon-\frac{4 a-x_{c 4}}{2 t}
\end{aligned}
$$

Essa equação diferencial é do tipo descrito no Apêndice B, e tem a seguinte solução:

$$
x_{c 4}(t)=K \sqrt{t}+4 a+2 \varepsilon t
$$


onde a constante $K$ deve ser determinada pela condição

$$
x_{c 3}\left(t_{4}^{0}\right)=x_{c 4}\left(t_{4}^{0}\right)
$$

ou seja,

$$
\begin{aligned}
5 a / 2 & =K \sqrt{3 a / 4 \varepsilon}+4 a+2 \varepsilon(3 a / 4 \varepsilon) \\
K & =-\frac{3 a}{\sqrt{3 a / 4 \varepsilon}}=-2 \sqrt{3 a \varepsilon}
\end{aligned}
$$

Assim,

$$
x_{c 4}(t)=4 a-2 \sqrt{3 a \varepsilon t}+2 \varepsilon t
$$

A velocidade deste choque fica, então, dada por:

$$
\frac{d x_{c 4}}{d t}=2 \varepsilon-\sqrt{\frac{3 a \varepsilon}{t}}
$$

O evento seguinte será um quinto choque, agora entre as duas regiões de rarefação e ocorre no instante $t_{5}^{0}$ em que a característica da família $x_{2}$ que parte de $x_{0}=0$ encontra o quarto choque;

- choque $5\left(x_{c 5}(t)\right)$, ocorre em $t_{5}^{0}$ dado por:

$$
\begin{aligned}
x_{r 2}\left(\rho_{r 1}=1 / 2-\varepsilon ; t_{5}^{0}\right) & =x_{c 4}\left(t_{5}^{0}\right) \\
2 \varepsilon t_{5}^{0} & =4 a-2 \sqrt{3 a \varepsilon t_{5}^{0}}+2 \varepsilon t_{5}^{0} \\
t_{5}^{0} & =\frac{4 a}{3 \varepsilon}
\end{aligned}
$$

A condição de Rankine-Hugoniot para este choque, utilizando as soluções 4.13 e 4.11 obtidas para as rarefações, nos dá:

$$
\begin{aligned}
\frac{d x_{c 5}}{d t} & =\frac{j\left(\rho_{r 2}\left(x_{c 5}\right)\right)-j\left(\rho_{r 1}\left(x_{c 5}\right)\right)}{\rho_{r 2}\left(x_{c 5}\right)-\rho_{r 1}\left(x_{c 5}\right)} \\
& =\frac{\left(1 / 2+\frac{4 a-x_{c 5}}{2 t}\right)\left(1 / 2-\frac{4 a-x_{c 5}}{2 t}\right)-\left(1 / 2+\frac{x_{c 5}}{2 t}\right)\left(1 / 2-\frac{x_{c 5}}{2 t}\right)}{\left(1 / 2+\frac{4 a-x_{c 5}}{2 t}\right)-\left(1 / 2-\frac{x_{c 5}}{2 t}\right)} \\
& =\frac{x_{c 5}-2 a}{t}
\end{aligned}
$$

Esta equação diferencial também é do tipo descrito no Apêndice B, e tem a seguinte solução:

$$
x_{c 5}(t)=2 a+K t
$$


sendo $K$ determinado pela condição:

$$
\begin{aligned}
x_{c 4}\left(t_{5}^{0}\right) & =x_{c 5}\left(t_{5}^{0}\right) \\
2 \varepsilon\left(\frac{4 a}{3 \varepsilon}\right) & =2 a+K\left(\frac{4 a}{3 \varepsilon}\right) \\
K & =\varepsilon / 2
\end{aligned}
$$

Temos então:

$$
x_{c 5}(t)=2 a+(\varepsilon / 2) t
$$

e a velocidade deste quinto choque fica dada por:

$$
\frac{d x_{c 5}}{d t}=\varepsilon / 2
$$

Como a velocidade deste choque é positiva, teremos ainda um sexto choque no instante $t_{6}^{0}$ em que o quinto choque encontra a característica da família $x_{5}$ que parte de $x_{0}=4 a$, ou seja, este choque se dá entre as características da primeira região de rarefação e aquelas da família $x_{5}$.

- choque $6\left(x_{c 6}(t)\right)$, ocorre em $t_{6}^{0}$ dado por:

$$
\begin{aligned}
x_{c 5}\left(t_{6}^{0}\right) & =4 a \\
2 a+(\varepsilon / 2) t_{6}^{0} & =4 a \\
t_{6}^{0} & =4 a / \varepsilon
\end{aligned}
$$

A condição de Rankine-Hugoniot para este choque nos dá:

$$
\begin{aligned}
\frac{d x_{c 6}}{d t} & =\frac{j\left(\rho\left(x_{5}\right)\right)-j\left(\rho_{r 1}\left(x_{c 5}\right)\right)}{\rho\left(x_{5}\right)-\rho_{r 1}\left(x_{c 5}\right)} \\
& =\frac{(1 / 2)[1-(1 / 2)]-\left(1 / 2+\frac{x_{c 6}}{2 t}\right)\left(1 / 2-\frac{x_{c 6}}{2 t}\right)}{(1 / 2)-\left(1 / 2-\frac{x 6}{2 t}\right)} \\
& =\frac{x_{c 6}}{2 t}
\end{aligned}
$$

cuja solução é:

$$
x_{c 6}(t)=K \sqrt{t}
$$

sendo $K$ determinado pela relação:

$$
\begin{aligned}
x_{c 6}\left(t_{6}^{0}\right) & =4 a \\
K \sqrt{4 a / \varepsilon} & =4 a \\
K & =2 \sqrt{a \varepsilon}
\end{aligned}
$$


Tabela 4.1: Propriedades dos choques para a condição inicial dada pela equação (4.3)

\begin{tabular}{|c|c|c|c|c|}
\hline choques & início & duração & distância percorrida & velocidade \\
\hline 1 & 0 & $a / 2 \varepsilon$ & $a / 2$ & $\varepsilon$ \\
2 & 0 & $a / 2 \varepsilon$ & $a / 2$ & $-\varepsilon$ \\
3 & $a / 2 \varepsilon$ & $a / 4 \varepsilon$ & 0 & 0 \\
4 & $3 a / 4 \varepsilon$ & $7 a / 12 \varepsilon$ & $a / 6$ & $2 \varepsilon-\sqrt{\frac{3 a \varepsilon}{t}}$ \\
5 & $4 a / 3 \varepsilon$ & $8 a / 3 \varepsilon$ & $4 a / 3$ & $\varepsilon / 2$ \\
6 & $4 a / \varepsilon$ & $\infty$ & $\infty$ & $\sqrt{\frac{a \varepsilon}{t}}$ \\
\hline
\end{tabular}

Assim, temos:

$$
x_{c 6}(t)=2 \sqrt{a \varepsilon t}
$$

e a velocidade deste choque fica, por sua vez, dada por:

$$
\frac{d x_{c 6}}{d t}=\sqrt{\frac{a \varepsilon}{t}}
$$

O fato dessa velocidade ser positiva implica que, para tempos longos (maiores que $t_{6}^{0}=$ $4 a / \varepsilon$ ), a solução da equação (4.2) para a condição inicial equação (4.3) será:

$$
\begin{aligned}
& \rho(x, t)=1 / 2 \text { para todo } x<0 \\
& \rho(x, t)=1 / 2-\frac{x}{2 t} \text { para } 0<x<4 a+\sqrt{\frac{a \varepsilon}{t}} \\
& \rho(x, t)=1 / 2 \text { para todo } 4 a+\sqrt{\frac{a \varepsilon}{t}}<x
\end{aligned}
$$

que, tomado o limite de tempo indo para infinito $(t \rightarrow \infty)$, nos dá novamente a condição anterior a perturbação de densidade uniforme igual a $1 / 2$ para todo o espaço.

Nosso interesse aqui reside principalmente na dinâmica dos choques, que queremos associar às propriedades observadas no movimento bidirecional de vesículas. A Tabela 4.1 mostra de forma compacta as propriedades calculadas para estes choques.

Temos então a seguinte solução para o estado transiente da equação (4.2), com a condição 
inicial (4.3):

$$
\begin{aligned}
& \rho(x, t)=1 / 2 \text { para todo } x<0 \text { e } t>0 \\
& \rho(x, t)=1 / 2-\frac{x}{2 t} \text { para } 0<x<2 \varepsilon t \text { e } t<\frac{4 a}{3 \varepsilon} \\
& \rho(x, t)=1 / 2-\frac{x}{2 t} \text { para } 0<x<2 a+(\varepsilon / 2) t \text { e } \frac{4 a}{3 \varepsilon}<t<4 a / \varepsilon \\
& \rho(x, t)=1 / 2-\frac{x}{2 t} \text { para } 0<x<4 a+\sqrt{\frac{a \varepsilon}{t}} \text { e } 4 a / \varepsilon<t \\
& \rho(x, t)=1 / 2-\varepsilon \text { para } 2 \varepsilon t<x<2 a+\varepsilon t \text { e } 0<t<a / 2 \varepsilon \\
& \rho(x, t)=1 / 2-\varepsilon \text { para } 2 \varepsilon t<x<5 a / 2 \text { e } a / 2 \varepsilon<t<3 a / 4 \varepsilon \\
& \rho(x, t)=1 / 2-\varepsilon \text { para } 2 \varepsilon t<x<4 a-2 \sqrt{3 a \varepsilon t}+2 \varepsilon t \text { e } 3 a / 4 \varepsilon<t<\frac{4 a}{3 \varepsilon} \\
& \rho(x, t)=1 / 2 \text { para } 2 a+\varepsilon t<x<3 a-\varepsilon t \text { e } 0<t<a / 2 \varepsilon \\
& \rho(x, t)=1 / 2+\varepsilon \text { para } 3 a-\varepsilon t<x<4 a-2 \varepsilon t \text { e } 0<t<a / 2 \varepsilon \\
& \rho(x, t)=1 / 2+\varepsilon \text { para } 5 a / 2<x<4 a-2 \varepsilon t \text { e } a / 2 \varepsilon<t<3 a / 4 \varepsilon \\
& \rho(x, t)=1 / 2+\frac{4 a-x}{2 t} \text { para } 4 a-2 \varepsilon t<x<4 a \text { e } 0<t<3 a / 4 \varepsilon \\
& \rho(x, t)=1 / 2+\frac{4 a-x}{2 t} \text { para } 4 a-2 \sqrt{3 a \varepsilon t}+2 \varepsilon t<x<4 a \text { e } 3 a / 4 \varepsilon<t<\frac{4 a}{3 \varepsilon} \\
& \rho(x, t)=1 / 2+\frac{4 a-x}{2 t} \text { para } 2 a+(\varepsilon / 2) t<x<4 a \text { e } \frac{4 a}{3 \varepsilon}<t<4 a / \varepsilon \\
& \rho(x, t)=1 / 2 \text { para } 4 a<x \text { e } 0<t<4 a / \varepsilon \\
& \rho(x, t)=1 / 2 \operatorname{para} 4 a+\sqrt{\frac{a \varepsilon}{t}}<x \text { e } 4 a / \varepsilon<t
\end{aligned}
$$

O perfil de densidade está mostrado em diversos instantes na Figura 4.3, onde representamos a posição de uma vesícula que inicialmente se localiza adjacente ao segundo choque. Esta vesícula apresentará um movimento para trás durante o tempo $a / 2 \varepsilon$, em seguida ficará em repouso por um tempo $a / 4 \varepsilon$, começará então um movimento no sentido de $\mathrm{x}$ positivo (para frente), caracterizando um movimento bidirecional, que sofrerá algumas variações, tanto em sentido como em magnitude, em sua velocidade. Qualitativamente, vemos que este tipo de movimento está de acordo com o que é observado experimentalmente para vesículas conduzidas por motores moleculares. 

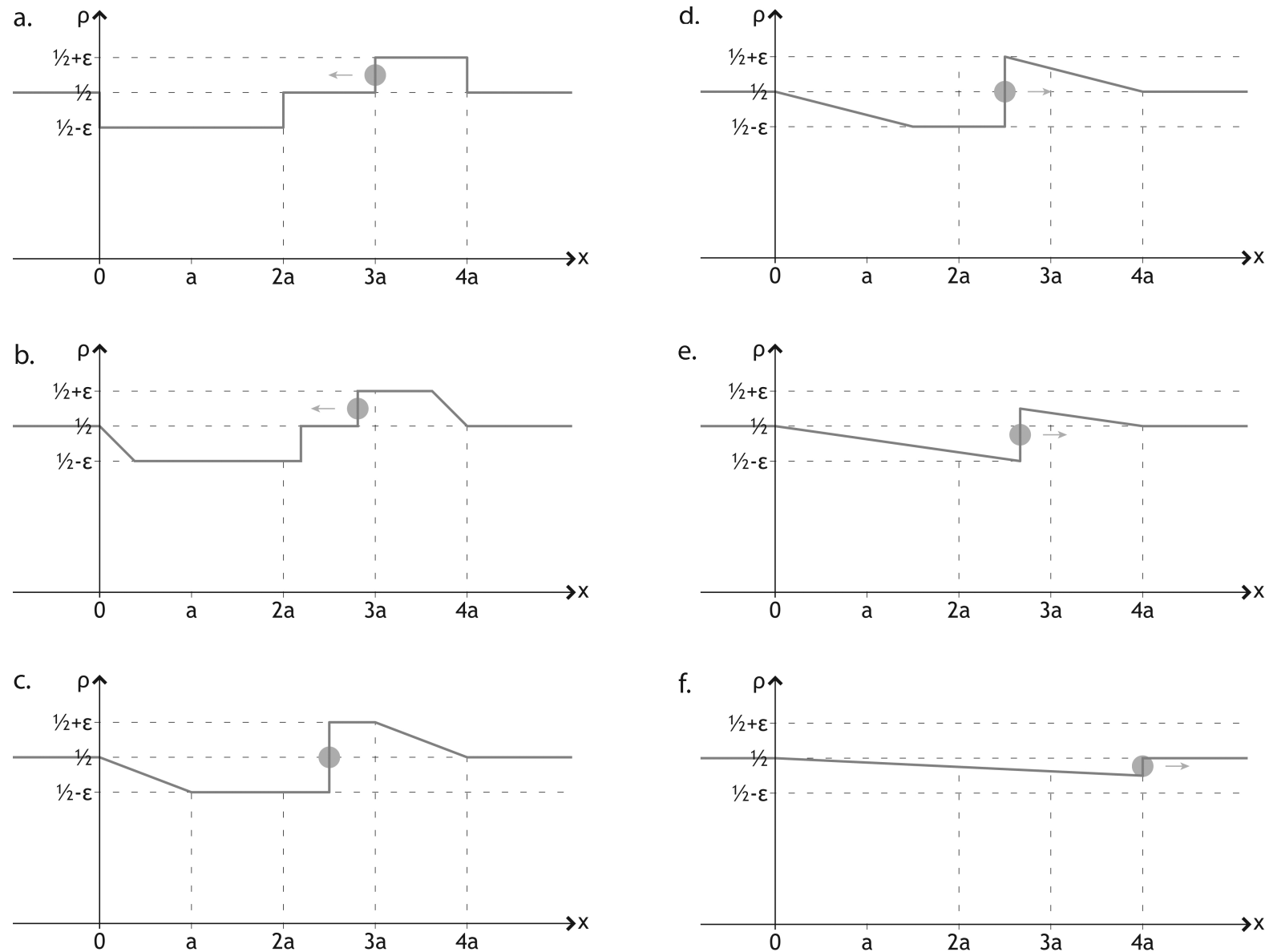

Figura 4.3: Perfil de densidade em diversos instantes do estado transiente de um TASEP, de acordo com solução (4.52). A vesícula é representada esquematicamente (disco cinza), acompanhando o movimento dos choques partindo do choque 2, a seta indica o sentido da velocidade naquele instante. (a) instante inicial $(t=0)$, os choques 1 e 2 se formam com a perturbação inicial, (b) perfil entre o instante inicial e $t_{3}^{0}=\frac{a}{2 \varepsilon}$, (c) instante $t_{3}^{0}=\frac{a}{2 \varepsilon}$ em que ocorre o terceiro choque, (d) instante $t_{4}^{0}=\frac{3 a}{4 \varepsilon}$ em que ocorre o quarto choque, (e) instante $t_{5}^{0}=\frac{4 a}{3 \varepsilon}$, quando se inicia o quinto choque, (f) instante $t_{6}^{0}=\frac{4 a}{\varepsilon}$ quando o último choque se inicia. 
A seguir, discutiremos como estes resultados obtidos aqui, através do nosso modelo, mostram-se frente aos resultados experimentais expostos no Capítulo 2. Discutiremos também as vantagens e desvatagens deste modelo frente àqueles encontrados na literatura. Vamos também levantar hipóteses sobre como a dinâmica que propomos para a vesícula pode ocorrer. Concluímos, por fim, que, apesar de nem todas as evidências experimentais estarem de acordo com este modelo, ele se mostra plausível e pode ser útil na interpretação de fenômenos de transporte onde muitos motores podem interagir. 


\section{Capítulo 5}

\section{Discussão sobre o modelo proposto}

No capítulo anterior propusemos um novo modelo para o entendimento do movimento bidirecional apresentado por estruturas intracelulares que se deslocam sobre microtúbulos. Este modelo, que associa a posição de tais estruturas àquela das possíveis descontinuidades na densidade de motores que se movem sobre um mesmo microtúbulo, pode ser considerado mesoscópio, uma vez que não atribui nenhum mecanismo microscópico ao fenômeno e assume apenas a interação de vários motores que, estes sim, obedecem aos mecanismos microscópicos descritos no Capítulo 1.

Neste capítulo vamos então, num primeiro momento, levantar hipóteses sobre como devem agir mecanismos moleculares que explicariam esta dinâmica mesoscópica das vesículas. Em seguida, veremos como este modelo permite algumas previsões de valores para parâmetros biofísicos do movimento, ainda que, dada a arbitrariedade da condição inicial escolhida, não possamos ir muito além da estimativa das ordens de grandeza envolvidas. Comparamos estes valores previstos com os dados experimentais que foram revisados no Capítulo 2. Por fim, discutimos as diferenças, vantagens e desvantagens, que nosso modelo apresenta em relação ao modelo atualmente mais aceito na explicação deste fenômeno (também revisado no Capítulo 2), o modelo que supõe a coordenação entre os diferentes tipos de motores que aparentemente estão presentes, simultaneamente, durante este modo de transporte.

\subsection{Um possível mecanismo molecular que explique nosso modelo mesoscópio}

Uma vez que queremos que a vesícula siga o choque em sua dinâmica microscópica, e não apenas mesoscópica, devemos propor um mecanismo molecular que mimetize o comportamento das partículas de segunda classe do modelo tratado por Derrida et al. (1993) [38]. 
Tais partículas, como explicamos no Capítulo 3, se comportam como buracos quando interagem com partículas de primeira classe, mas como partículas comuns quando encontramse frente a buracos.

Assim, precisamos de um mecanismo molecular que nos dê a seguinte dinâmica para a vesícula lipídica: se houver um monômero livre do filamento à sua frente, ela se move como se fosse simplesmente um motor (do mesmo tipo encontrado "livre", se movendo sobre o filamento), mas passa a se comportar como buraco quando ela se encontra adjacente a um monômero ocupado por um motor "livre". Deste modo, se a partícula se encontra em regiões rarefeitas ela deve se comportar como um motor típico, andando pra frente. Ao se deparar com uma região de alta densidade de motores livre, ela começará a andar de acordo com o choque, seguindo o movimento deste, como se ela fosse o último dos motores livres desta região de alta densidade, para frente (caso os motores a sua frente se movam) ou para trás (caso continuem chegando motores livres da região de trás do choque).

Para que isso seja possível, ou seja, para que a vesícula seja capaz de realizar o movimento em ambas as direções, ela deve possuir, associados à sua superfície, tanto motores capazes de se mover em direção à extremidade-menos quanto à extremidade-mais. De fato, conforme vimos no Capítulo 2, é isto que se observa experimentalmente. O que propomos, portanto, é que, em meio a muitos motores de um mesmo tipo que se movem unidirecionalmente sobre o microtúbulo, a vesícula utilize este mesmo tipo de motor ao se encontrar numa região rarefeita, enquanto utiliza o outro tipo de motor para se deslocar na direção oposta quando ela se encontra numa região de alta densidade de motores. Deste modo, em cada direção, o trabalho realizado no movimento da vesícula é atribuído aos motores conhecidos, que, de acordo com os modelos estudados no Capítulo 1, são capazes de aproveitar a energia liberada na hidrólise do ATP para realizar um movimento unidirecional.

\subsection{Comparação das previsões teóricas do modelo pro- posto com dados experimentais}

Inúmeros sistemas experimentais têm sido estudados quanto ao transporte intracelular dos mais diferentes objetos, como vesículas lipídicas, grânulos de pigmento, mitocôndria, vírus etc. Todos estes objetos citados já foram observados, em algum modelo experimental, apresentando movimento bidirecional. Entretanto, apenas alguns destes sistemas permitiram, até aqui, a boa caracterização deste movimento quanto aos parâmetros biofísicos de interesse. Como vimos no Capítulo 2, um destes sistemas é o embrião de Drosophila, que possui vesículas lipídicas que têm sido muito estudadas quanto ao movimento bidirecional que apresentam ao longo de três fases do desenvolvimento embrionário. A seguir vamos comparar os dados experimentais descritos para este sistema com as previsões que 
nosso modelo nos permite fazer.

Para obtermos, com nosso modelo, valores numéricos para as grandezas observadas experimentalmente, como a velocidade e as distâncias percorridas em uma corrida típica, devemos estimar os parâmetros $a$ e $\varepsilon$ do nosso modelo (introduzidos na condição inicial (4.3)). As vesículas lipídicas em questão apresentam um diâmetro médio de 0,5 $\mu m$ [31]. Esta grandeza deve, de acordo com nosso modelo, ser da mesma ordem do parâmetro $a$, uma vez que este parâmetro indica o tamanho da perturbação causada pela vesícula ao se aproximar do microtúbulo. Nosso modelo prevê corridas que apresentem distâncias típicas com valores de $a / 6, a / 2$ e $4 a / 3$ (que, adotando o valor $0,5 \mu \mathrm{m}$ para $a$, ficam $83 \mathrm{~nm}, 250 \mathrm{~nm}$ e $666 \mathrm{~nm}$, respectivamente), além do sexto choque com distâncias "infinitas" (como não ocorrem reversões posteriores a partícula seguiria até o fim do filamento). Experimentalmente se observa que o valor médio para a distância de uma corrida em direção à extremidade-menos praticamente não varia entre as fases do desenvolvimento embrionário e é de cerca de $610 \mathrm{~nm}$, o que se aproxima razoavelmente de $4 a / 3=666 \mathrm{~nm}$, deste modo associaríamos uma corrida típica em direção à extremidade-menos ao movimento do quinto choque. Já para o movimento em direção à extremidade-mais, a distância média percorrida numa corrida muda de $842 \mathrm{~nm}$ para $415 \mathrm{~nm}$, valores que não se encontram tão próximos daqueles previstos acima.

Entretanto, até aqui estamos utilizando os valores médios de uma corrida típica observada, sem considerar que estatisticamente foram identificados [29], para o movimento em cada direção, dois tipos diferentes de corridas, as corridas "longas-rápidas" e aquelas "curtas-lentas", como descrito no Capítulo 2. As corridas em direção à extremidade-menos apresentam distâncias típicas de cerca de $90 \mathrm{~nm}$ para as corridas do tipo "curto-lento" e de 1050 nm para aquelas do tipo "longo-rápido". Para as corridas em direção à extremidademais, na fase 2 do desenvolvimento embrionário, observa-se distâncias típicas de $67 \mathrm{~nm}$ para corridas do tipo "curto-lento" e $1144 \mathrm{~nm}$ para aquelas do tipo "longo-rápido", enquanto para a fase 3 do desenvolvimento embrionário, observa-se distâncias típicas de $96 \mathrm{~nm}$ para corridas do tipo "curto-lento" e $780 \mathrm{~nm}$ para aquelas do tipo "longo-rápido". Os valores observados para as distâncias percorridas nas corridas longas parecem ser da ordem de 2 vezes o tamanho da vesícula, o que não está de acordo com o nosso modelo, conforme será esclarecido adiante. Entretanto, os valores de distância observados para as corridas curtas parecem estar bastante próximos do que o nosso modelo prevê para o quarto choque que percorre uma distância da ordem de $a / 6=83 \mathrm{~nm}$.

A estimativa do parâmetro $\varepsilon^{1}$ é mais difícil pois, a princípio, este parâmetro do modelo

\footnotetext{
${ }^{1}$ dimensão de $\varepsilon$ : O parâmetro $\varepsilon$ foi introduzido no modelo como uma variável adimensional associada à densidade de partículas. Na tabela 4.1 este parâmetro aparece com dimensão de velocidade pois, aí, $\varepsilon$ está multiplicada por K, que não aparece explicitamente porque na equação (4.2) teve seu valor igualado a -1. Portanto, na análise que fazemos aqui, ao associarmos valores de velocidade ao $\varepsilon$, estamos de fato associando tais valores à $K \varepsilon$.
} 
indicaria a amplitude da perturbação causada pela vesícula. Entretanto, esta perturbação ainda não foi observada experimentalmente, ela foi apenas hipotetizada por nós. Podemos, no entanto, associar o valor deste parâmetro às velocidades das vesículas de acordo com a Tabela 4.1 para, então, calcularmos os valores esperados para a duração de uma corrida típica em cada direção. De acordo com a Tabela 4.1, as velocidades desenvolvidas pelos choques podem assumir continuamente os valores de zero a $\varepsilon / 2$ ou os valores $\varepsilon$ ou $-\varepsilon$. Vimos no Capítulo 2 que as vesículas apresentam, para corridas em direção à extremidademenos do tipo "longo-rápido", velocidades da ordem de $430 \mathrm{~nm} / \mathrm{s}$ e, para aquelas do tipo "curto-lento", velocidades da ordem de $200 \mathrm{~nm} / \mathrm{s}$. Vemos que, a princípio, esta razão de pouco mais de duas vezes entre as velocidades dos movimentos rápido e lento é prevista por nosso modelo. Vamos então procurar associar os choques 1 e 2 às corridas "longasrápidas" e o choque 4 às corridas "curtas-lentas".

Se tomarmos $\varepsilon=400 \mathrm{~nm} / \mathrm{s}$, obtemos tempos de duração de $a / 2 \varepsilon=0,625 \mathrm{~s}$ para os os primeiros dois choques, $7 a / 12 \varepsilon=0,729 s$ para o quarto choque e $8 a / 3 \varepsilon=3,33 s$ para o quinto choque (o sexto tem duração "infinita"). Estes valores não se mostram muito próximos do valor observado de $5 s$ como tempo médio entre duas reversões [29] (ver Capítulo 2). Entretanto, $\operatorname{com} \varepsilon=200 \mathrm{~nm} / \mathrm{s}$ os tempos de duração destes choques serão dobrados, ficando entre 1,25 s e 6,66 s. Estes valores são razoavelmente próximos do valor médio de 5 segundos de duração observados para corridas na direção menos. Porém, agora estaríamos associando uma velocidade de apenas $200 \mathrm{~nm} / \mathrm{s}$ para a corrida do tipo "longa-rápida" e de $100 \mathrm{~nm} / \mathrm{s}$ para aquela do tipo "curta-lenta", valores que são aproximadamente a metade daqueles observados experimentalmente. Entretanto, vale notar que estes mesmos valores seriam obtidos se, em vez de tomarmos $\varepsilon=200 \mathrm{~nm} / \mathrm{s}$, tormarmos $a=1000 \mathrm{~nm}$.

A ocorrência do terceiro choque daria origem a um intervalo de tempo em que a vesícula fica parada. A duração deste choque nos dá um tempo de parada de $a / 4 \varepsilon=300 \mathrm{~ms}$, se assumimos $\varepsilon=400 \mathrm{~nm} / \mathrm{s}$. Este valor também é a metade do valor médio observado experimentalmente [29] e, assim como os valores acima, também ficaria bastante próximo do observado se o valor que atribuímos à variável $a$ fosse duplicado.

Os choques 5 e 6 , seriam choques que continuariam infinitamente na mesma direção do quarto choque, mas com alterações da velocidade. Como este movimento continuaria infinitamente, consideramos que estes choques sejam menos relevantes, uma vez que em algum momento os motores devem perder o contato com o filamento (a processividade se torna limitante). 


\subsection{Vantagens e desvatagens apresentadas pelo mo- delo proposto}

O modelo que propomos neste trabalho busca explicar o movimento bidirecional de objetos intracelulares, por nós chamados genericamente de "vesículas", que se deslocam às custas do trabalho gerado por motores moleculares ao interagirem com microtúbulos através de aspectos mesoscópicos do sistema (como a geometria da vesícula e sobretudo o fluxo de motores interagentes sobre o microtúbulo).

Vemos que, de acordo com as comparações feitas na seção anterior, este modelo apresenta choques que podem descrever qualitativamente o movimento bidirecional de uma vesícula se esta tiver sua posição associada a eles, uma vez que temos choques se movendo em ambas as direções com padrões que conseguimos associar aos movimentos "longos-rápidos" e "curtos-lentos" descritos para as vesículas. Quantitativamente, nota-se uma concordância razoável (ao menos em ordens de grandeza) entre os valores estimados com o nosso modelo e aqueles observados para as variáveis envolvidas. Esta concordância não é perfeita, sendo notada uma diferença de aproximadamente duas vezes entre os valores observados e aqueles previstos pelo modelo. Entretanto, esta discordância seria corrigida se o diâmetro efetivo da vesícula, ou seja, se a extensão espacial da perturbação inicial, que associamos ao parâmetro $a$, fosse duas vezes maior do que o diâmetro médio observado por Welte et al. [31]. Deste modo, esta discordância pode indicar simplesmente que a vesícula consegue perturbar uma região maior do filamento do que consideramos.

É importante notar que analisamos apenas os dados relativos a um único sistema experimental, sendo conhecido o fato de serem observadas grandes variações entre os dados obtidos num sistema e aqueles obtidos em outro. Portanto, uma concordância quanto à ordem de grandeza dos parâmetros físicos do movimento que são medidos experimentalmente já é um resultado satisfatório, uma vez que tal modelo pode ser aplicado com melhores resultados em outro sistema. Como dissemos no Capítulo 2, a escolha de um sistema experimental particular para o estudo fenomenológico do modelo se deu apenas pela relativa abundância de dados experimentais sobre o movimento bidirecional de vesículas lipídicas em embriões de Drosophila.

A principal diferença em relação aos modelos vigentes é que o modelo apresentado aqui assume que existem motores que não estão associados à vesículas se movendo unidirecionalmente sobre o mesmo filamento em que ocorre o movimento bidirecional da vesícula, e que estes motores livres podem influenciar o movimento desta vesícula. Apesar de inúmeros experimentos in vitro mostrarem que motores se deslocam sobre o microtúbulo na ausência de vesículas e recentemente um experimento ter observado que tais motores interagem e podem ocorrer choques entre regiões de densidades distintas [32], os modelos encontrados na literatura em nenhum momento exploram a possibilidade de existirem tais 
motores livres se deslocando sobre o filamento no meio intracelular.

Quanto à regulação do movimento, nosso modelo supõem que esta se dê na maneira como a vesícula perturba a densidade de motores que se encontra no filamento. Deste modo, o controle passa pela forma da vesícula e o modo como esta influencia o movimento dos motores livres, que ditaria se o movimento resultante seria em direção à extremidademais ou à extremidade-menos. A direção final do movimento não poderia, portanto, ser mudada no decorrer deste processo de transporte. Mudanças no ambiente só alterariam o movimento em curso se levarem a uma nova perturbação na densidade de motores livres, o que parece ser difícil de atribuir a mudanças observadas pela presença de fatores de crescimento (como a que ocorre no caso de mitocôndrias [53]). Caso contrário, a única maneira de mudar o sentido do movimento seria mudar a perturbação inicial, que a pricípio supomos ser determinada unicamente pela geometria da vesícula.

Pelo que conhecemos da literatura, o modelo proposto aqui parece ser o primeiro a atribuir a regulação do movimento à própria vesícula. Este fato pode representar uma vantagem para sistemas em que cada tipo de objeto (dada sua geometria específica) deve ser invariavelmente transportado para o mesmo destino, o que talvez tenha sido explorado pela natureza ao longo da evolução e explique o movimento bidirecional ao menos em alguns casos. Pode-se pensar, por exemplo, no caso dos vírus, que devem ter sido selecionados evolutivamente para se moverem no meio intracelular sempre em direção ao núcleo. Tais objetos, coincidentemente ou não, possuem uma geometria bem definida. Pode-se também imaginar diversas aplicações tecnológicas em que este fato representa uma vantagem.

Uma aparente deficiência do nosso modelo é que, a princípio, todos os tipos de movimento ocorrem com igual freqüência. Isso vai contra o que foi descrito por Gross et al. (2000) [29] que associam a mudança na direção do deslocamento médio entre as fases 2 e 3 do desenvolvimento embrionário à uma diminuição na freqüência do movimento "longo-rápido", em relação ao "curto-lento", na direção da extremidade-mais. Entretanto, podemos argumentar que, apesar de um dado tipo de vesícula apresentar um movimento onde as freqüências relativas dos vários tipos de movimento não se alteram, uma alteração da geometria das vesículas poderia explicar uma mudança no movimento de forma global, levando a uma alteração das freqüências relativas observadas. Deste modo explicaríamos as mudanças observadas por Gross et al. como conseqüências de alterações na geometria das vesículas (ou no modo como estas perturbam os motores livres ao interagirem com o filamento).

O modelo que propomos não está necessariamente em completo desacordo com os modelos mais aceitos para explicar o movimento bidirecional, podendo compartilhar com estes alguns de seus aspectos. Vimos na primeira seção deste capítulo que uma explicação molecular para o nosso modelo deve passar pelos mesmos mecanismos de geração de força suspostos nos modelos encontrados na literatura. Na nossa proposta também supomos 
que motores de tipos diferentes devem estar presentes simultaneamente na superfície da vesícula. Supomos, entretando, que a regulação da atividade destes motores se dê por um mecanismo sensível à presença de motores livres, o que seria diferente dos mecanismos regulatórios propostos na literatura (mas ainda não desvendados experimentalmente). 


\section{Conclusão}

Neste trabalho estudamos diversas abordagens teóricas para o estudo do transporte intracelular mediado por motores moleculares e tentamos fazer uma conexão entre elas. Inicialmente apresentamos um estudo dos modelos que explicam como é possível a realização de força por parte destes motores moleculares, que atuam numa escala onde o ruído térmico é importante, e como este ruído pode ser utilizado em prol do próprio movimento vetorial destes motores. Estes modelos foram chamados por nós de modelos mínimos, uma vez que buscam explicar como se dá o movimento destes motores com o menor número possível de suposições.

No segundo capítulo procuramos apresentar os sistemas biológicos em questão, nos voltando sobretudo para os dados experimentais relativos a um fenômeno observado em muitos destes sistemas: o movimento bidirecional de objetos intracelulares.

Em seguida, apresentamos uma outra abordagem teórica ao transporte mediado por partículas motoras. Estudamos, no terceiro capítulo, os modelos unidimensionais do tipo TASEP e ASEP que consideram um sitema de partículas interagentes (através de volume excluído) que se movem numa rede unidimensional de modo assimétrico. Estes são os exemplos mais simples de sistemas conhecidos como "sistemas difusivos dirigidos", caracterizados por taxas de transição que não satisfazem balanço detalhado e, portanto, não existem medidas de Gibbs associadas aos estados estacionários [79]. Deste modo, tais sistemas já estão a priori fora de equilíbrio termodinâmico, mas consegue-se fazer de modo natural a associação entre estes sistemas e os modelos mínimos para uma partícula motora vistos no primeiro capítulo, que explicam como estes estados de não-equilíbrio geram trabalho mecânico. No terceiro capítulo mostramos também como modelos do tipo ASEP/TASEP produzem fenômenos como choques, regiões em que a densidade de partículas motoras muda abruptamente. Este estudo foi realizado no limite do contínuo com aproximação de campo médio, mas apresenta os mesmos resultados obtidos por métodos exatos [35]. Isso nos encorajou a estudar, neste limite, estados transientes do TASEP, permitindo uma análise mais detalhada do movimentos dos possíveis choques (que estão presentes mesmo em escala microscópica [38]) .

No quarto capítulo fornecemos uma explicação alternativa para o movimento bidire- 
cional de vesículas e outros objetos celulares, baseada no movimento dos choques que podem estar presentes quando partículas interagentes se deslocam simultaneamente sobre um filamento unidimensional - de acordo com os modelos vistos no terceiro capítulo. Atribuímos, portanto, grande importância a presença de motores livres se movendo simultaneamente sobre o filamento. A análise dos estados transientes de sistemas do tipo ASEP/TASEP mostrou que é possível atribuir o movimento bidirecional de vesículas e outros objetos intraceulares ao movimento dos choques, que podem surgir de perturbações em estados estacionários do sistema. Achamos razoável supor que a própria vesícula, ao entrar em contato com o microtúbulo, seja capaz de produzir tal perturbação na densidade de motores livres que supomos estar em movimento sobre o filamento.

Vimos que, mesmo parametrizando tais perturbações com apenas dois parâmetros ( $a$ e $\varepsilon)$, conseguimos descrever algumas características quantitativas do dados experimentais. Este modelo, entretanto, permite extensões que introduzam elementos adicionais. Uma extensão natural seria considerar mais parâmetros para caracterizar o perfil inicial da perturbação. Pode-se imaginar também a sobreposição de efeitos decorrentes de outras dinâmicas como uma dinâmica de Langmuir que procura considerar a processividade limitada dos motores, como foi descrito por Parmeggiani et al. [33].

Esta nossa explicação para o movimento bidirecional, através do efeito coletivo dos motores e não apenas de propriedades intrínsecas de cada motor, tem conseqüências importantes no modo como deve ocorrer o controle deste tipo de movimento. De acordo com nossa proposta, a vesícula, através de sua geometria e do modo como ela influencia os motores que se movem sobre o filamento, determina como se dará o seu próprio movimento, que passa a ser relativamente independente de fatores externos (a não ser por novas perturbações na densidade de motores livres). A regulação externa deve ocorrer, portanto, antes do início do movimento, através de mudanças na própria vesícula ou, talvez, nos motores "presos" à ela. Este modo de regulação é extremamente distinto dos modos que normalmente são considerados, que propõem, sobretudo, a regulação da atividade ou da coordenação dos motores. Estas diferenças devem permitir que se distinguam, experimentalmente, estas explicações alternativas para o fenômeno da bidirecionalidade. Outra evidência experimental que pode corroborar nosso modelo é a visualização de motores livres se deslocando sobre os microtúbulos em experimentos in vivo. Caso isso não seja visualisado, passa a ser necessária uma explicação de porquê isso ocorre nos experimentos in vitro [32] e não in vivo.

Concluímos que, apesar de não se ter grandes evidências experimentais favoráveis a este novo modelo para transporte vesicular, ele nos oferece resultados bastante razoáveis, merecendo ser analisado com mais cuidado por cientistas experimentais da área, que podem buscar evidências mais contundentes a seu favor ou contra ele. Este modelo já se mostra interessante por fornecer uma explicação alternativa para o transporte bidirecional que, mesmo não sendo aquela que melhor descreve o movimento intracelular, pode ser utilizada 
eventualmente em aplicações tecnológicas (uma vez que a dinâmica das partículas e as intereções supostas são relativamente simples), bastando para isso que seja desenvolvida uma partícula que se comporte como as partículas de segunda espécie do modelo estudado por Derrida et al. [38].

Consideramos, por fim, que nosso modelo poderá ser útil no entendimento de um fenômeno que parece estar longe de ser completamente entendido. A bidirecionalidade no transporte de estruturas intracelulares apresenta-se de diversas maneiras de acordo com o sistema experimental investigado, sendo possivelmente necessários modelos diferentes para entedê-la em cada caso. A boa compreensão deste fenômeno é de extremo interesse para as ciências bio-médicas, dados os inúmeros processos em que ele parece estar envolvido (citados na introdução) e aos enormes danos que alterações neste modo de transporte parecem acarretar às células envolvidas. Além disso, dadas as diferenças entre o movimento bidirecional e o movimento unidirecional, que podem muitas vezes ser vistas como vantagens (conforme comentado no Capítulo 2), um bom entendimento deste fenômeno é interessante se quisermos um dia fazer uso tecnológico destes modos de transporte. O fato de serem conhecidos diversos modelos teóricos capazes de explicar como a bidirecionalidade pode ser obtida possibilita que diversas estratégias sejam empregadas na tentativa de desenvolver mecanismos de transporte que façam uso do movimento bidirecional, ajudando no desenvolvimento desta tecnologia, mesmo que alguns destes modelos não se mostrem de acordo com o que se observa no interior das células. 


\section{Apêndice A}

Neste apêndice pretendemos expor o método das características para a resolução de equações diferenciais parciais. Este apêndice foi elaborado com base nas explicações dadas por Habermann no livro "Elementary Applied Partial Differential Equations" [86] e no apêndice da Dissertação de Mestrado de Fernando Goldenstein Carvalhaes [87].

\section{A-1 Equações Diferenciais Lineares}

Uma equação diferencial parcial (EDP) linear, no caso mais simples, pode ser escrita na forma:

$$
\frac{\partial \rho}{\partial t}+c \frac{\partial \rho}{\partial x}=0
$$

onde $c$ é uma constante. Gostaríamos de obter uma solução $\rho(x, t)$ para uma dada condição inicial do tipo:

$$
\rho(x, 0)=\rho_{0}(x)
$$

O método das características consiste em comparar a $\operatorname{EDP}(\mathrm{A}-1)$ com a derivada total em relação ao tempo da função $\rho(x, t)$, supondo que esta é medida para o referencial que não observa mudanças na função $\rho(x, t)$. A função $x(t)$ que parametriza o referencial que satifaz isto é chamada de função característica.

Para a função $\rho$, a regra da cadeia implica que:

$$
\frac{d}{d t} \rho(x(t), t)=\frac{\partial \rho}{\partial t}+\frac{d x}{d t} \frac{\partial \rho}{\partial x}
$$

Comparando a equação diferencial (A-1) com a derivada total da função (A-3) vemos que, com

elas se identificam se tivermos:

$$
\frac{d x}{d t}=c
$$

$$
\frac{d \rho}{d t}=0
$$

Deste modo, fica claro que se um observador se move sobre a característica $x(t)$, a função $\rho$ não se altera, ou seja, $\rho(x(t), t)$ é constante para um observador que se move com 


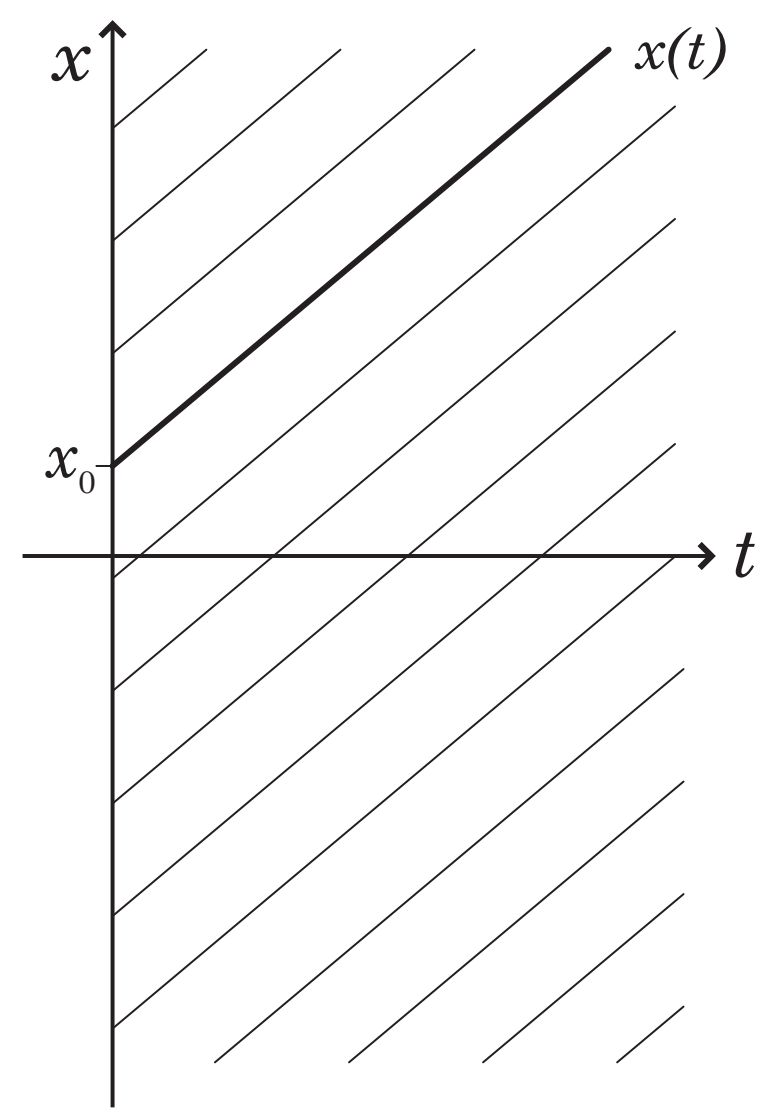

Figura A-1: Família de características lineares definidas pela equação (A-6). Cada valor de $x_{0}$ define uma curva característica $x(t)$ específica.

velocidade $c$. Neste sentido, a equação diferencial (A-1) foi substituída por duas equações ordinárias (A-4) e (A-5)

Quando integramos a equação (A-4) obtemos a função

$$
x(t)=c t+x_{0}
$$

Na verdade temos, assim, uma família de curvas (retas, no caso), para diferentes valores de $x_{0}$, ao longo das quais, caminhando com velocidade $c$, não se observa variação de $\rho(x, t)$ como mostra a Figura A-1. Estas curvas são conjuntamente chamadas de "família de características" e para um dado $x_{0}$ temos uma característica.

O procedimento final para resolver a equação é escrever $x_{0}$ em função de $x$ e $t$, e então voltar para a condição inicial do problema. Desta maneira, a solução final será:

$$
\rho(x, t)=\rho_{0}\left(x_{0}(x, t)\right)
$$

Como exemplo, podemos resolver pelo método das características a equação de continuidade (A-1), com uma condição inicial do tipo pulso quadrado (A-2). Neste caso, 


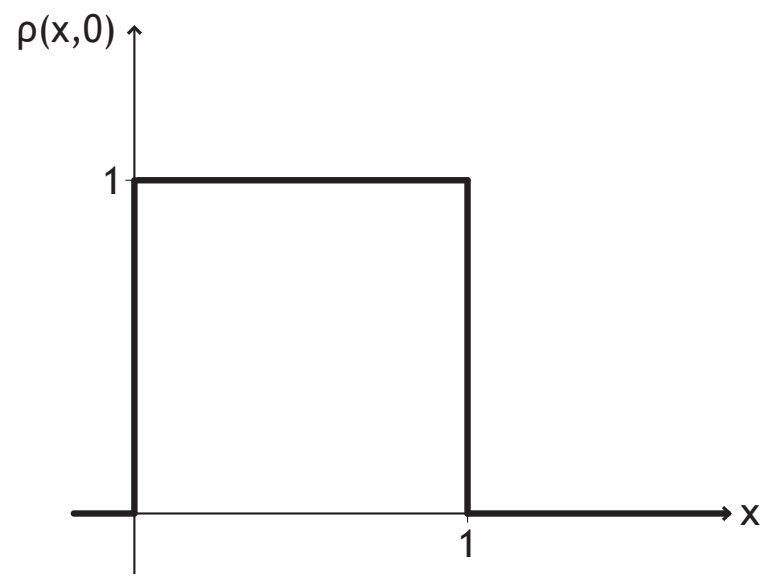

Figura A-2: Condição inicial definida na equação (A-9).

as características são dadas por:

$$
x=c t+x_{0}, \forall t
$$

Com a seguinte condição inicial:

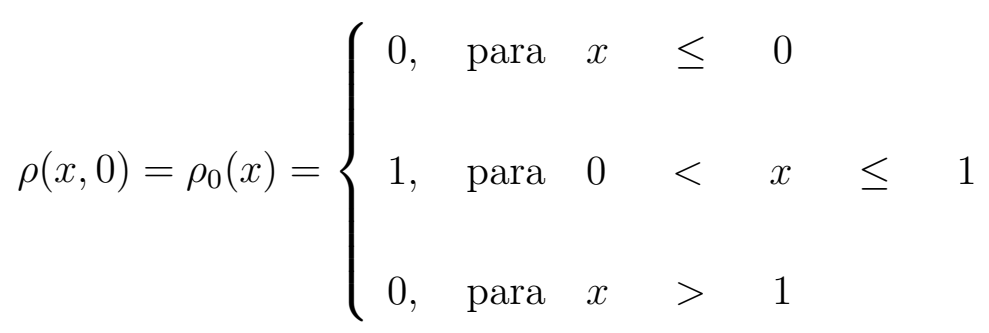

A Figura A-2 ilustra a condição inicial (A-9).

Comparando com a derivada total da função $\rho$,

$$
\frac{d}{d t} \rho(x(t), t)=\frac{\partial \rho}{\partial t}+\frac{d x}{d t} \frac{\partial \rho}{\partial x}
$$

identificamos:

$$
\begin{gathered}
\frac{d}{d t} \rho(x(t), t)=0 \\
\frac{d x}{d t}=c
\end{gathered}
$$

Que leva às seguintes características:

$$
x\left(x_{0}, t\right)=x_{0}+c t, \forall x_{0}, t
$$

de onde determinamos,

$$
x_{0}(x, t)=x-c t, \forall x, t
$$




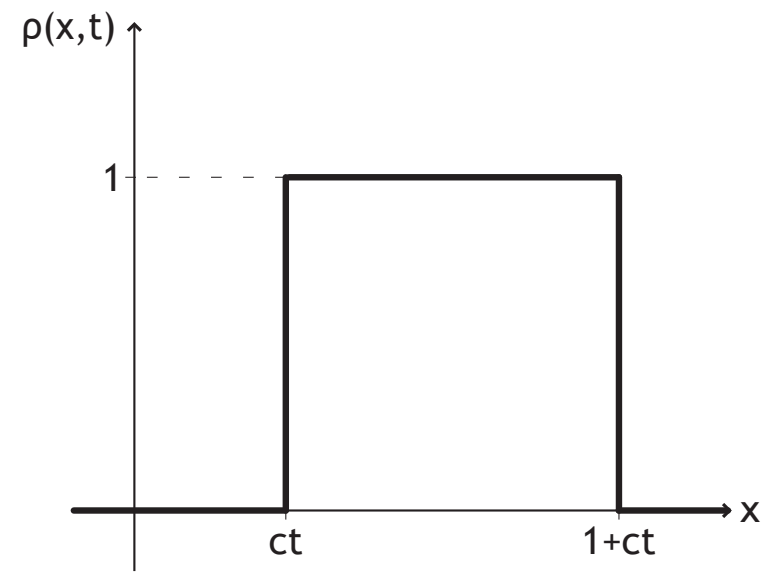

Figura A-3: Solução (A-15) da equação (A-1) para a condição inicial (A-9).

Podemos então montar a solução de (A-1), através das características, voltando nas condições iniciais.

$$
\rho(x, t)=\rho_{0}\left(x_{0}(x, t)\right)=\left\{\begin{array}{l}
0, \quad \text { para } x \leq c t \\
1, \quad \text { para } c t<x \leq 1+c t \\
0, \quad \text { para } x>1+c t
\end{array}\right.
$$

Esta solução está representada na Figura A-3.

\section{A-2 Equações Quasi-lineares}

O procedimento introduzido até agora diz respeito a equações cujo termo que multiplica a derivada espacial é constante. Veremos a seguir como proceder em casos em que isto não ocorre. Vamos nos restringir aqui ao caso de uma equação quasi-linear homogênea (caso que emgloba as equações encontradas neste trabalho), do tipo:

$$
\frac{\partial \rho(x, t)}{\partial t}+c(\rho(x, t)) \frac{\partial \rho(x, t)}{\partial x}=0
$$

Cuja quasi-linearidade é devida ao termo $c(\rho(x, t))$ que multiplica a derivada espacial, ser função da própria função $\rho(x, t)$. Não se trata de uma equação diferencial não-linear, uma vez que ela é linear em suas derivadas parciais.

A solução é analoga ao caso linear, utilizando-se o mesmo procedimento de comparar e 
identificar os termos entre a equação (A-16) e a derivada total de $\rho(x, t)$, temos:

$$
\begin{aligned}
\frac{d \rho(x, t)}{d t} & =0 \\
\mathrm{e} & \\
\frac{d x(t)}{d t} & =c(\rho(x, t))
\end{aligned}
$$

Desta maneira a equação diferencial parcial (A-16) se reduz ao sistema de equações diferenciais ordinárias (A-17).

A integral da equação (A-17) nos dá:

$$
\begin{aligned}
\rho(x, t) & =\rho(x, 0) \\
& =\rho_{0}\left(x_{0}\right)
\end{aligned}
$$

e a integral da equação (A-18) fica

$$
x=c\left(\rho_{0}\left(x_{0}\right)\right) t+x_{0}
$$

e temos assim a família de trajetórias especiais definidas pela condição inicial ao longo das quais não se observa variação em $\rho(x, t)$, chamada de família das característica, ou simplesmente características.

Uma característica que emana de $x=x_{0}$ é determinada utilizando-se a condição inicial $\rho(x, 0)=\rho_{0}\left(x_{0}\right)$. Ao longo desta característica, a solução $\rho(x, t)$ muda de acordo com a equação para $\rho(x, t)$ em (A-17). Outras condições iniciais levam a outras características, o que gera a família de características para a determinada condição inicial.

Dependendo das condições iniciais, podem ocorrer ondas de rarefação ou choque, fenômenos que ocorrem como conseqüência do fato de termos características não mais paralelas, que se distanciam ou se cruzam no tempo.

\section{A-2.1 Ondas de rarefação}

Este fenômeno ocorre quando temos condições iniciais descontínuas, de maneira que as características que se iniciam num ponto $x_{0}$ de menor valor tenham velocidades $c(\rho(x, t))$ menores que as daquelas que partem de valores maiores de $x_{0}$, levando a um distanciamento no tempo, como indica a Figura A-4.

Neste caso, a solução da equação para a região entre as características que se afastam região de rarefação - é obtida preenchendo-se, para cada instante $t>0$, os valores de $\rho$ entre aqueles indicados para cada uma das famílias de características adjacentes ao ponto de descontinuidade da condição inicial. Deste modo, para $t>0$, a solução $\rho$ passa a ser contínua. 


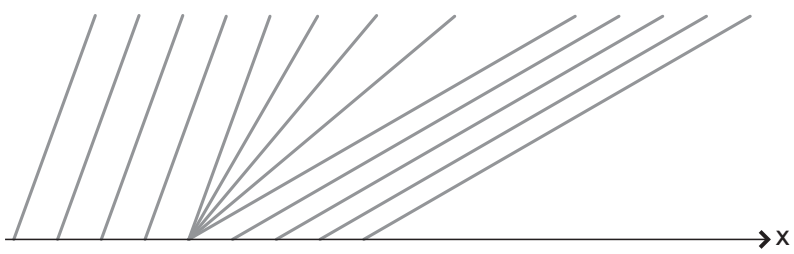

Figura A-4: Representação gráfica de duas famílias de características com velocidades tais que se forma uma região de rarefação entre elas.

\section{A-2.2 Ondas de choque}

No caso de equações quasi-lineares também é comum que as características se encontrem em instantes futuros. Isto ocorre quando a condição inicial é tal que $c\left(\rho\left(x_{1}, 0\right)\right)>$ $c\left(\rho\left(x_{2}, 0\right)\right)$, onde $x_{1}<x_{2}$. Neste caso, a característica partindo do ponto $x_{0}=x_{1}$ possui maior velocidade de propagação que aquela característica que parte do ponto $x_{0}=x_{2}$ e, portanto, irá alcança-la após um intervalo de tempo finito, como indica a Figura A-5.

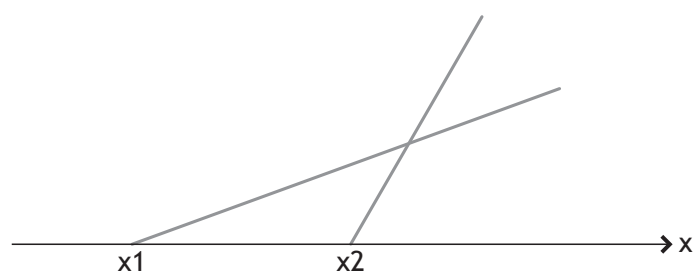

Figura A-5: Ondas de choque: Características que partem de diferentes valores de $x_{0}$ em $t=0$, nos quais a condição inicial é diferente, e se interceptam em um tempo posterior, levam a uma solução descontínua. Esta descontinuidade é conhecida como choque ou onda de choque.

Neste ponto $(x, t)$ em que as características se interceptam, teríamos duas soluções para nossa equação diferencial $\rho\left(x_{1}, 0\right)$ e $\rho\left(x_{2}, 0\right)$. Para contornar este problema, o que se faz é assumir que neste ponto a densidade $\rho$ tem uma descontinuidade, que será chamada de choque.

O choque ocorre em uma posição $x_{s}(t)$ que se propaga no tempo. Chamemos de $x_{s^{-}}$e $x_{s^{+}}$ as posições imediatamente à esquerda e à direita do choque, de modo que teremos duas soluções distintas, $\rho\left(x_{s^{-}}, t\right)$ e $\rho\left(x_{s^{+}}, t\right)$.

Utilizando uma analogia com a equação de continuidade:

$$
\frac{\partial \rho}{\partial t}+\frac{\partial j}{\partial x}=0
$$

onde $j(x, t)$ deve ser interpretado como o fluxo de partículas (número de pratículas que passam pelo ponto x e num instante t, por unidade de tempo). Se a velocidade instantânea 
da partícula é $u$, temos $j=\rho u$ (onde $u$ também pode depender de $\rho$ ).

Ocorre que, sendo esta uma equação de conservação, o fluxo de partículas deve ser conservado mesmo na descontinuidade. Em outras palavras, o fluxo relativo ao choque de um lado da descontinuidade deve ser o mesmo que o do outro lado:

$$
j_{-}^{r}=j_{+}^{r}
$$

Ecreveremos agora esta equação com os fluxos em termos da densidade e da velocidade das partículas de cada lado do choque. Lembrando que o choque se move, para que o fluxo de partículas através da descontinuidade se conserve, devemos considerar a velocidade das partículas relativa ao choque em cada lado deste $\left[u\left(x_{s^{-}}, t\right)-d x_{s} / d t\right.$ e $\left.u\left(x_{s^{+}}, t\right)-d x_{s} / d t\right]$, temos assim:

$$
\rho\left(x_{s^{-}}, t\right)\left[u\left(x_{s^{-}}, t\right)-\frac{d x_{s}}{d t}\right]=\rho\left(x_{s^{+}}, t\right)\left[u\left(x_{s^{+}}, t\right)-\frac{d x_{s}}{d t}\right]
$$

que pode ser re-escrita, de modo a nos fornecer a velocidade do choque, ou seja, a velocidade com que o ponto de descontinuidade da nossa solução se move.

$$
\begin{aligned}
\frac{d x_{s}}{d t} & =\frac{\rho\left(x_{s^{+}}, t\right) u\left(x_{s^{+}}, t\right)-\rho\left(x_{s^{-}}, t\right) u\left(x_{s^{-}}, t\right)}{\rho\left(x_{s^{+}}, t\right)-\rho\left(x_{s^{-}}, t\right)} \\
& =\frac{j\left(x_{s^{+}}, t\right)-j\left(x_{s^{-}}, t\right)}{\rho\left(x_{s^{+}}, t\right)-\rho\left(x_{s^{-}}, t\right)}
\end{aligned}
$$

Esta equação é conhecida como condição de Rankine-Hugoniot, e indica que a velocidade de choque é igual ao salto dado pelo fluxo dividido pelo salto dado pela densidade, ao atravessar o choque. Vale lembrar que esta condição decorre diretamente do fato da quantidade $\int \rho d x$ ser conservada, ou seja, esta condição só vale se a equação diferencial considerada supõem consevação se escrita na forma integral.

De cada lado do choque a solução é obtida normalmente, "retornando" à condição inicial pelas características que aí se encontram (ver equação (A-7)). 


\section{Apêndice B}

Neste apêndice, elaborado a partir das explicações encontradas no livro "Calculus" de Tom M. Apostol [88], vamos mostrar qual é a solução geral de equações diferenciais do tipo:

$$
\frac{\partial y(t)}{\partial t}=y(t) g(t)+f(t)
$$

e em seguida tentaremos justificar rapidamente a generalidade da solução apresentada. A prova desta solução e de sua unicidade para uma condição inicial específica pode ser encontrada na referência acima.

A solução geral da equação (B-1) é:

$$
y(t)=k U(t)+U(t) \int \frac{f(t)}{U(t)} d t
$$

onde $k$ é uma constante a ser determinada pela condição inicial e $U(t)$ é um fator integrante dado por:

$$
U(t)=\exp \left\{\int g(t) d t\right\}
$$

Esta solução é de fácil verificação, basta substituí-la na equação (B-1): derivado-se a equação (B-2) temos

$$
\frac{\partial y(t)}{\partial t}=\frac{\partial U(t)}{\partial t}\left(k+\int \frac{f(t)}{U(t)} d t\right)+f(t)
$$

Como a definição do fator $U(t)$, dado pela equação (B-3), nos dá:

$$
\frac{\partial U(t)}{\partial t}=g(t) \exp \left\{\int g(t) d t\right\}=g(t) U(t)
$$

a equação (B-4), fica:

$$
\frac{\partial y(t)}{\partial t}=g(t)\left[k U(t)+U(t) \int \frac{f(t)}{U(t)} d t\right]+f(t)
$$

Que, lembrando da equação (B-2), nada mais é que a equação (B-1). 


\section{Bibliografia}

[1] Hess, H. Toward Devices Powered by Biomolecular Motors. Science, 312 (2006) 860 $-861$.

[2] Vale, R. D. The Molecular Motor Toolbox for Intracellular Transport. Cell, 112 (2003) $467-480$.

[3] Hurd, D. D., Saxton, W. M. Kinesin Mutation Cause Motor Neuron Disease Phenotypes by Disrupting Fast Axonal Transport in Drosophila. Genetics, 144 (1996) 1075 -1085 .

[4] Nonaka, S., Tanaka, Y., Okada, Y., Takeda, S., Harada, A., Kanai, Y., Kido, M., e Hirokowa, N. Randomization of Left-Right Asimmetry Due to Loss of Nodal Cilia Generating Leftward Flow of Exatraembryonic Fluid in Mice Lacking KIF13B Motor Protein. Cell, 95 (1998) 829 - 837.

[5] Pazour, G. J., Dickert, B. L., Vucica, Y., Seeley, E. S., Rosenbaum, J. L., Witman, G. B., e Cole, D. G. Chlamydomonas IFT88 and its Mouse Homologue, Policystic Kidney Disease Gene tg737, are Required for Assembly of Cilia and Flagella. J. Cell Biol., 151 (2000) 709 - 718.

[6] Lin, F., Hiesberger, T., Corde, K., Sinclair, A. M., Goldstein, L. S. B., Somlo, S., e Igarashi, P. Kidney-specific inactivation of KIF3A subunit of Kinesin-II inhibits renal ciliogenesis and produces polycystic kidney disease. Proc. Natl. Acad. Sci. USA, 100 (2003) $5286-5291$.

[7] Zhao, C., Takita, J., Tanaka, Y., Setou, M., Nakagawa, T., Takeda, S., Yang, H. W., Terada, S., Nakata, T., Takei, Y., et al. Chacot-Marie-Tooth Disease Type 2A Caused by Mutation in a Microtubule Motor KIF1B $\beta$. Cell, 105 (2001) 587 - 597.

[8] Reid, E., Kloos, M., Ashley-Koch, A., Hughes, L., Bevan, S., Svenson, I. K., Graham, F. L., Gaskell, P. C., Dearlove, A., Pericak-Vance, M. A., et al. A Kinesin Heavy Chain (KIF5A) Mutation in Hereditary Spastic Paraplegia (SPG10). Am. J. Hum. Genet., 71, (2002) 1189 - 1194. 
[9] Anikster, Y., Huizing, M., Anderson, P. D., Fitzpatrick, D. L., Klar, A., GrossKieselstein, E., Berkun, Y., Shazberg, G., Gahl, W. A., e Hurvitz, H. Evidence that Griscelli Syndrome with Neurological Involvement is Caused by Mutations in RAB27A, not MYO5A. Am. J. Hum. Genet., 71 (2002) $407-414$.

[10] Goldstein, L. S. Kinesin molecular motors: Transport pathways, receptors and human disease. Proc. Natl. Acad. Sci. USA, 98 (2001) 6999 - 7003.

[11] Guanawardena, S. and Goldstein, L. S. Cargo-carring motor vehicles on the neuronal highway: transport pathways and neurodegenerative disease. J. Neurolobiol., 58 (2004) $258-271$.

[12] McGuire, J. R., Rong, J., Li, S., Li, X. Interaction of Huntingtin-associated Protein-1 with Kinesin Light Chain. J. Biol. Chem., 281 (2006) 3552 - 3559.

[13] Suomalainen, M., Nakano, M. Y., Keller, S., Boucke, K., Stidwill, R. P., e Greber, U. F. Microtubule-dependent plus- and minus end-directed motilities are competing process for nuclear targeting of adenovirus. J. Cell Biol., 144 (1999) 657 - 672.

[14] Rietdorf, J., Ploubidou, A., Reckmann, I., Holmstrom, A., Frischknecht, F., Zettl, M., Zimmermann, T., e Way, M. Kinesin dependent movement on microtubules precedes actin-based motility of vaccinia virus. Nat. Cell Bio., 3 (2001) $992-1000$.

[15] Smith, G. A., Gross, S. P., Enquist, L. W. Herpesviruses use bidirectional fast-axonal transport to spread in sensory neurons. Proc. Natl. Acad. Sci. USA, 98 (2001) 3466 -3470 .

[16] Welte, M. A. Bidirectional Transport along microtubules. Curr. Biol., 14 (2004) R525 - R537.

[17] Alberts, B., Johnson, A., Lewis, J., Raff, M., Roberts, K., Walter, P. The molecular biology of The Cell. Forth edition. New York: Garland Science, 2002. Chpter 14: Energy Conversion: Mitochondria and Chloroplasts, p. 767 - 829. ISBN 0-81533218-1.

[18] Uemura, S., Higushi, H., Olivares, A. O., De La Cruz, E. M. e Ishiwata, S. Mechanochemical coupling of two substeps in a single myosin V motor. Nat. Struct. Mol. Biol., 11 (2004) $877-883$.

[19] Mallik, R., Carter, B. C., Lex, S. A., King, S. J., Gross, S. P. Cytoplasmic dynein functions as a gear in reponse to load. Nature, 427 (2004) $649-652$.

[20] Hill, L. T. Free Energy and Kinetics of Biochemical Diagrams, Including Active Transport. Biochemistry, 14 (1975) 2127. 
[21] Landman, U., Montroll, E. W., e Shlesinger, M. F. Random walks and generalized master equations with internal degrees of freedom. Proc. Natl. Acad. Sci. USA, 74 (1977) $430-433$.

[22] Adjari, A., Prost, J. Mouvement Induit par un Potentiel Périodique de Basse Symétrie: Diéletrophorèse Pulsée. C. R. Acad. Sci. Paris, t. 315 Série II (1992) $1635-1639$.

[23] Magnasco, M. O. Forced Thermal Ratchets Phys. Rev. Lett., 71 (1993) 1477 - 1481.

[24] Astumian, R. D. e Bier, M. Fluctuation Driven Rachets: Molecular Motors. Phys. Rev. Lett., 72 (1994) $1766-1769$.

[25] Feynman, R. P., Leighton, R. B. e Sands,. The Feynman Lactures on Physics. Vol. I. Reading MA: Addison-Wesley, 1963. Chapter 46: Ratchet and pawl, p. 46-1 - 46-9. ISBN 0-201-02116-1.

[26] Astumian, R. D. Adiabatic Theory of Fluctuation-Induced Transport on a Periodic Potential. J. Phys. Chem., 100 (1996) 19075 - 19081.

[27] Gross, S. P. Hilther and Yon: A Review of bi-Directional Microtubule-Based Transport, Phys. Biol., 1 (2004) R1 - R11.

[28] Sheetz, M. P. Motor and Cargo Interactions, Eur. J. Biochem., 262 (1999) 19 - 25.

[29] Gross, S. P., Welte, M. A., Block, S. M., e Wieschaus, E. F. Dynein-Mediated Cargo Transport In Vivo: A Switch Controls Travel Distance, J. Cell Biol.,148 (2000) 945 -955 .

[30] Murray, J. W., Bananis, E., e Wolkoff, A. W. Reconstitution of ATP-dependent Movement of Endocytic Vesicles Along Microtubules In Vitro: An Oscillatory Bidirectional Process, Mol. Biol. Cell, 11 (2000) 419 - 433.

[31] Welte, M. A., Gross, S. P., Postner, M., Block, S. M. e Wieschaus, E. F. Developmental Regulation of Vesicle Transport in Drosophila Embryos: Forces and Kinetics, Cell, 92 (1998) $547-557$.

[32] Nishinari, K., Okada, Y., Schadschneider, A. e Chowdhury, D. Intracellular Transport of Single-Headed Molecular Motors KIF1A. Phys. Rev. Lett., 95 (2005) 118101-1118101-4.

[33] Parmeggiani, A., Franosch, T. e Frey, E.Phase Coexistence in Driven OneDimensional transport. Phys. Rev. Lett., 90 (2003) 086601-1 - 086601-4.

[34] Derrida, B., Domany, E. e Mukamel, D. An Exact Solution of a One-Dimensional Asymmetric Exclusion Model with Open Boundaries. J. Stat. Phys. 69 (1992) 667 687. 
[35] Derrida, B., Evans, M. R., Hakim, V., e Pasquier, V. Exact Solution of a 1D Asymetric Exclusion Model Using a Matrix Formulation, J. Phys. A: Math. Gen., 26 (1993) $1493-1517$.

[36] Andjel, E. D., Bramson, M., Liggett, T. M. Shocks in the asymmetric exclusion process. Prob. Theor. Rel. Fields, 78 (1988) 231.

[37] Ferrari, P., Kipnis, C., Saada, E. Microcospic Structure of Travelling Waves in the Asymetric Simple Exclusion Process. Ann. Prob., 19 (1991) 226.

[38] Derrida, B., Janowsky, S. A., Lebowitz, J. L. e Speer, E. R. Microscopic-Shock Profiles: Exact Solution of a Non-equilibrium System, Europhys. Lett., 22 (1993) 651-656. Derrida, B., Janowsky, S. A., Lebowitz, J. L. e Speer, E. R. Exact Solution of the Totally Asymetric Simple Exclusion Process: Shock Profiles, J. Stat. Phys., 73 (1993) $813-842$.

[39] Xing, J., Wang, H. e Oster, G. From Continuum Fokker-Plank Models to Discrete Kinetic Models. Biophys. J., 89 (2005) $1551-1563$.

[40] Karplus, M. e McCammon, J. A. Molecular dynamics simulations of biomolecules. Nat. Struct. Biol., 9 (2002) $646-652$.

[41] Karplus, M. e Kuriyan, J. Molecular dynamics and protein function. Proc. Nat. Acad. Sci. USA, 102 (2005) $6679-6685$.

[42] Tomé, T. e Oliveira, M. J. Dinâmica Estocástica e Irreversibilidade. São Paulo: Editora da Universidade de São Paulo, 2001. Cap. 6: Equação Mestra, p. 101 - 121. ISBN 85-314-0595-5.

[43] Liu, D. S., Astumian, R. D. e Tsong, T. Y. Activation of $\mathrm{Na}^{+}$and $\mathrm{K}^{+}$Pumping Modes of (Na,K)-ATPase by an Oscillating Eletric Field. J. Biol. Chem., 265 (1990) 7260 .

[44] Xie, T. D., Marszalek, P., Chen, Y. e Tsong, T. Y. Recognition and Processing of Randomly Fluctuating Eletric Signals by Na,K-ATPase. Biophys. J., 67 (1994) 1247.

[45] Lifson, S. e Jackson, J. L. On the Self-Diffusion of Ions in a Polyelectrolyte Solution. J. Chem. Phys., 36 (1962) $2410-2414$.

[46] Svoboda, K., Schmidt, C. F., Schnapp, B. J., Block, S. M. Direct observation of kinesin molecules. Nature, 365 (1993) $721-727$.

[47] Vale, R. D., Funatsu, T., Pierce, D. W., Romberg, L., Harada, Y, Yanagida, T. Direct observation of single kinesin molecules moving along microtubules. Nature, 380 (1996) $451-453$. 
[48] Kural, C., Kim, H., Syed, S., Goshima, G., Gelfand, V. I., Selvin, P. R. Kinesin and Dynein Move a Peroxisome in Vivo: A Tug-of-War or Coordinated Movement? Science, 308 (2005) 1469 - 1472.

[49] Funatsu, Harada, Y, Tokunaga, M., Salto, K., Yanagida, T. Imaging of single molecules and individual ATP turnovers by single myosin molecules in aqueous solution. Nature, 374 (1995) 555 - 559.

[50] Ishijima, A. Yanagida, T. Single Molecule Nanabioscience. Trends Biochem. Sci., 26 (2001) $438-444$.

[51] Toba, S., Watanabe, T. M. ,Yamagushi-Okimoto, L., Toyoshima, Y. Y., Higushi, H. Overlaping hand-over-hand mechanism of single molecular motility of cytoplasmic dynein. Proc. Nat. Acad. Sci. USA, 103 (2006) $5741-5745$.

[52] Schütz, G. J., Axmann, M., Freudenthaler, S., Schindler, H., Kandror, K., Roder, J. C. e Jeromin, A. Visualization of Vesicle Transport Along and Between Distinct Pathways in Neurites of Living Cells, Microsc.Res.Tec., 63 (2004) 159 - 167.

[53] Chada, S. R., Hollenbeck, P. J. Mitochondrial movement and positioning in axons: the role of growth factor signaling. J. Exp. Biol., 206 (2003) 1985 - 1992.

[54] De Vos, K. J., Sable, J., Miller, K. E., Sheetz, M. P. Expression of phosphatidylinositol $(4,5)$ biphospahte-specific pleckstrin homology domains alters direction but not the level of axonal transport of mithocondria. Mol. Biol. Cell, 14 (2003) 3636 - 3649.

[55] Morris, R. L., Hollenbeck, P. J. The regulation of bidirectional mitochondrial transport is coordinated with axonal out-growth. J. Cell Sci., 104 (1993) $917-927$.

[56] Wu, X., Bowers, B., Rao, K., Wei, Q., Hammer, J. A. Visualisations of melanosomes dynamics within wild-type and dilute melanocytes suggests a paradigm for Myosin V function in vivo. J. Cell Biol., 143 (1998) 1899 - 1918.

[57] Gross, S. P., Tuma, M. C., Deacon, S. W., Serpinskaya, A. S., Reilein, A. R., Gelfand, V. I. Interactions and regulation of molecular motor in Xenopus melanophores. $J$. Cell Biol., 156 (2002) 855 - 865.

[58] Rodionov, V., Yi, J., Kashina, A., Oladipo, A., Gross, S. P. Switching between microtubule- and actin-based transport systems in melanophores is controled by cAMP levels. Curr. Biol., 13 (2003) 1837 - 1847.

[59] Willard, M. Rapid directional translocations in virus replication. J. Virol., 76 (2002) 5220 - 5232.

[60] Alberts, B., Johnson, A., Lewis, J., Raff, M., Roberts, K., Walter, P. The molecular biology of The Cell. Forth edition. New York: Garland Science, 2002. Chpter 16: The Cytoskeleton, p. 907 - 982. ISBN 0-8153-3218-1. 
[61] Ligon, L. A., Tokito, M., Finklestein, J. M., Grossman, F. E., Holzbaur, E. L. Direct interaction between cytoplasmic dynein and kinesin I may coordinate motor activity. J. Biol. Chem., 279 (2004) $19201-19208$.

[62] Deacon, S. W., Serpinskaia, A. S., Vaughan, P. S., Fanarraga, M. L., Vemos, I., Vaughan, K. T., Gelfand, V. I., Dynactin is required for bidirectional organelle transport. J. Cell Biol.,160 (2003) $297-301$.

[63] Culver-Hanlon, T., Lex, S. A., Stephens, A. D., Quintyne, N. J., King, S. J. A microtubule-binding domain in dynactin increases dynein processivity by skating along microtubules. Nat. Cell Biol., 8 (2006) $264-270$.

[64] Ross, J. L., Wallace, K., Shuman, H., Goldman, Y. E., Holzbaur, E. L. F. Processive bidirectional moion of dynein-dynactin complexes in vitro. Nat. Cell Biol. , 8 (2006) $562-570$.

[65] Smith, D. A. How processive is the myosin-V motor? J. Muscle Research and Cell Motility, 25 (2004) 215 - 217.

[66] Hill, D. B., Plaza, M. J., Bonin, K. e Holzwarth, G. Fast Vesicle Transport in PC12 Neurite: Velocities and Forces, Eur. Biophys. J., 33 (2004) 623 - 632.

[67] Gross, S. P., Welte, M. A., Block, S. M., e Wieschaus, E. F. Coordination of oppositepolarity microtubule motors J. Cell Biol., 156 (2002) 715 - 724.

[68] Foe, V. E., Alberts, B. M. Studies of nuclear and cytoplasmic behavior during the five mitotic cycles that precede gastrulation. J. Cell. Sci., 61 (1983) $31-70$.

[69] Edgar, B. A., Odell, G. M., Schubiger, G. Cytoarchitecture and the patterning of fushi tarazu expression in the Drosophila blastoderm. Genes Dev., 1 (1987) 1226 1237.

[70] Ma, S., Chisholm,R. L. Cytoplasmic dynein-associated structures move bidirectionally in vivo. J. Cell Sci., 115 (2002) $1453-1460$.

[71] Rogers, S. L., Tint, I. S., Fanapour, P. C., Gelfand, V. I., Regulated bidirectional motility of melanophore pigment granules along microtubules in vitro. Proc. Natl. Acad. Sci. USA, 94 (1997) 3720 - 3725.

[72] Valetti, C., Wetzel, D. M., Schrader, M., Hasbani, M. J., Gill, S. R., Kreis, T. E., Schroer, T. A. Role of dynactin in endocytic traffic: effects of dynamitin overexpression and colocalization with CLIP-170. Mol. Biol. Cell, 10 (1999) 4107 - 4120.

[73] Waterman-Stroer, C. M., Karki, S. B., Kuznetsov, S. A., Tabb, J. S., Weiss, D. G., Langford, G. M., Holzbaur, E. L, The interaction between cytoplasmic dynein and dynactin is required for fast axonal transport. Proc. Natl. Acad. Sci. USA, 94 (1997) $12180-2185$. 
[74] Janowsky, S. A. e Lebowitz, J. L. Finite-size effects and shock fluctuations in the asymmetric simple-exclusion process. Phys. Rev. A, 45 (1992) $618-625$.

[75] Kolomeisky, A. B., Schütz, G. M., Kolomeisky, E. B. e Straley, J. P. Phase diagram of one-dimensional driven lattice gases with open boundaries. J. Phys. A: Math. Gen., 31 (1998) $6911-6919$.

[76] Aghababie, Y., Menon, G. I. e Plischke, M. Universal properties of interacting Brownian motors.Phys. Rev. E, 59 (1999) 2578 - 2586.

[77] Chowdhury, D. Traffic Flow of Interacting Self-Driven Particles: Rails and Trail, Vehicles and Vesicles. Physica Scripta, T106 (2003) 13 - 18.

[78] Liggett, T. T. Ergodic theorems for the asymetric simple exclusion process, Trans. Amer. Math. Soc., 213 (1976) 237-261. Liggett, T. T. Ergodic theorems for the asymetric simple exclusion process II, Ann. Prob., 5 (1977) 795 - 801.

[79] Schmittmann, B., Critical behavior of the driven diffusive lattice gas, Int. J. Mod. Phys., 4 (1990) 2269 - 2306.

[80] Parmeggiani, A., Franosch, T. e Frey, E. Totally Asymmetric Simple Exclusion Process with Langmuir Kinetics, Phys. Rev. E, 70 (2004) 046101-1 - 046101-20.

[81] Krug, J. Boundary-Induced Phase Transitions in Driven Difusive Systems. Phys. Rev. Lett., 76 (1991) $1882-1885$, .

[82] Evans, M. R., Foster, D. P., Godrèche, C. e Mukamel, D. Spontaneous Symmetry Breaking in a One-Dimensional Driven Diffusive System. Phy s. Rev. Lett., 74 (1995) $208-211$.

[83] Evans, M. R. Bose-Einstein Condensation in Disordered Exclusion Models And Relation to Traffic Flow. e-print cond-mat/9606036 v1 (2006).

[84] Krug, J. e Ferrari, P. Phase transitions in driven systems with random rates. J. Phys. A: Math. Gen., 29 (1996) L465 - L471.

[85] Evans, M. R. Condensation Transitions in Nonequilibrium Systems, e-print condmat/0401341 v1 (2004).

[86] Haberman, R. Elementary Applied Partial Differential Equations. Third edition. Prentice Hall, 1998. Chapter 11: The Method of characteristics for Linear and QuasiLinear Wave Equantions, p. 417 - 447. ISBN 0-13-263807-X.

[87] Carvalhaes, F. G. O papel da virulência na evolução da adaptabilidade de uma população de parasitas. São Paulo: Istituo de Física; Universidade de São Paulo, 2005. 143 p. Dissertação de Mestrado em Física. 
[88] Apostol, T. M. Calculus. Vol. I. Second Edition. New York: John Wiley \& Sons, Inc. 1967. Chapter 8: Introduction to Differential Equations. p 305 - 357. ISBN 0-471-00005-1. 